Nevada

Environmental

Restoration

Project

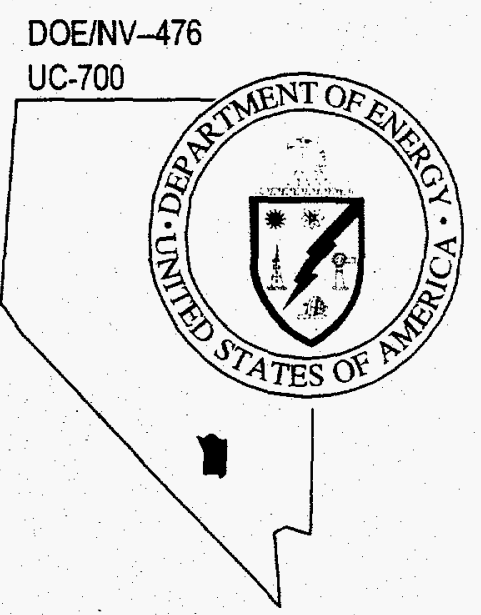

Corrective Action Investigation Plan

for CAU No. 424:

Area 3 Landfill Complex,

Tonopah Test Range, Nevada

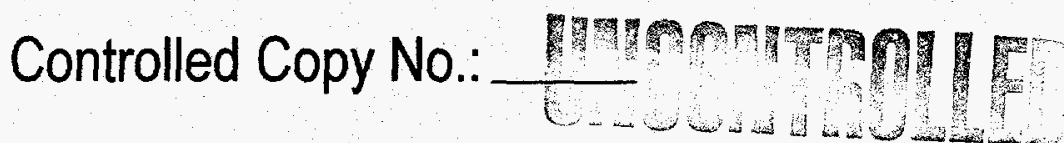

$$
\begin{aligned}
& \text { RECEIVED } \\
& \text { SEP } 2999 \\
& \text { OSTI }
\end{aligned}
$$

Revision No.: 0

DISTREUTHON OF THIS DOCUMENT IS UNWMTIED

April 1997

\title{
MASTER
}

Environmental Restoration

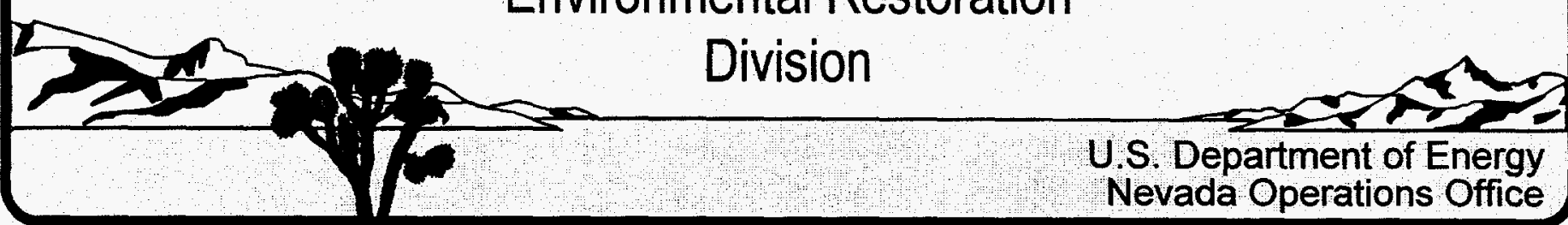


This report has been reproduced directly from the best available copy.

Available to DOE and DOE contractors from the Office of Scientific and Technical Information, P.O. Box 62, Oak Ridge, TN 37831; prices available from (423) 576-8401.

Available to the public from the National Technical Information Service, U.S. Department of Commerce, 5285 Port Royal Road, Springfield, VA 22161, telephone (703) 487-4650. 


\section{CORRECTIVE ACTION INVESTIGATION PLAN FOR CAU NO. 424: AREA 3 LANDFILL COMPLEX, TONOPAH TEST RANGE, NEVADA}

DOE Nevada Operations Office

Las Vegas, Nevada

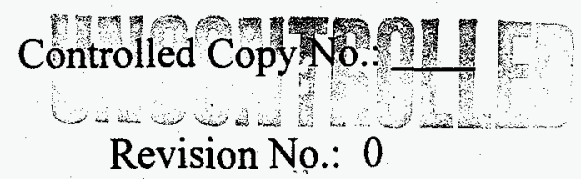

April 1997 


\section{DISCLAIMER}

This report was prepared as an account of work sponsored by an agency of the United States Goverament. Neither the United States Governmeat aor any agency thereof, nor any of their employees, makes any warranty, express or implied, or assumes any legal liability or responsibility for the accuracy, completeness, or usefulness of any information, apparatus, product, or process disclosed, or represents that its use would not infringe privately owned rights. Reference berein to any specific commercial product, process, or service by trade name, tradernart. manufacturer, or otherwise does not necessarily constitute or imply its endorsement, recommendation, or favoring by the United States Governmeat or any ageacy thereof. The views and opinions of authors expressed herein do not necessarijy state or reflect those of the. United States Government or any agency thereof. 


\section{DISCLAIMER}

Portions of this document may be illegible in electronic image products. Images are produced from the best available original document. 


\section{CORRECTIVE ACTION INVESTIGATION PLAN}

FOR CAU NO. 424:

AREA 3 LANDFILL COMPLEX, TONOPAH TEST RANGE, NEVADA

\footnotetext{
Approved by: Sanet Vepenell - W's Janet Appenzeller-Wing, Project Manager Industrial Sites Subproject
}

Date: $4 / 24 / 97$

\footnotetext{
Approved by: Robent opl. Canginter ys. Stephen A. Mellington, Project Manager Nevada Environmental Restoration Project
} 


\section{Table of Contents}

List of Figures

List of Plates v

List of Tables iv

List of Acronyms and Abbreviations vi

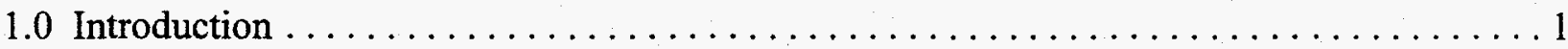

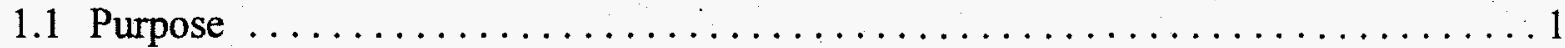

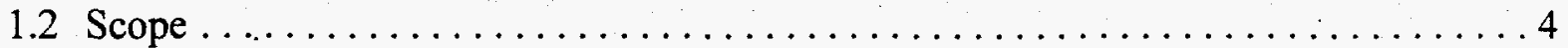

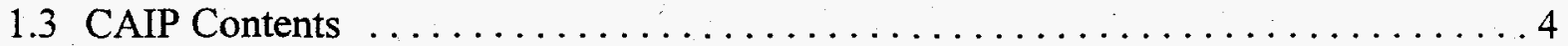

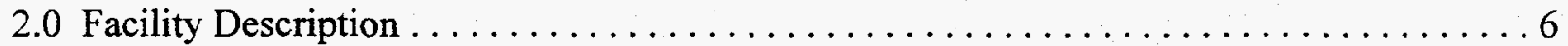

2.1 Site Assessment and Operational History $\ldots \ldots \ldots \ldots \ldots \ldots \ldots \ldots \ldots \ldots \ldots \ldots \ldots \ldots \ldots \ldots \ldots$

2.1.1 Landfill A3-1 (CAS No. 03-08-001-A3-01) .................. 6

2.1.2 Landfill A3-2 (CAS No. 03-08-002-A3-02) $\ldots \ldots \ldots \ldots \ldots \ldots \ldots \ldots$

2.1.3 Landfill A3-3 (CAS No. 03-08-003-A3-03) …............. 9

2.1.4 Landfill A3-4 (CAS No. 03-08-004-A3-04) $\ldots \ldots \ldots \ldots \ldots \ldots \ldots \ldots 11$

2.1.5 Landfill A3-5 (CAS No. 03-08-005-A3-05) $\ldots \ldots \ldots \ldots \ldots \ldots \ldots \ldots$

2.1.6 Landfill A3-6 (CAS No. 03-08-006-A3-06) .................. 15

2.1.7 Landfill A3-7 (CAS No. 03-08-007-A3-07) $\ldots \ldots \ldots \ldots \ldots \ldots \ldots \ldots$

2.1.8 Landfill A3-8 (CAS No. 03-08-008-A3-08) …............. 18

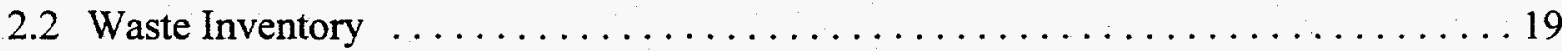

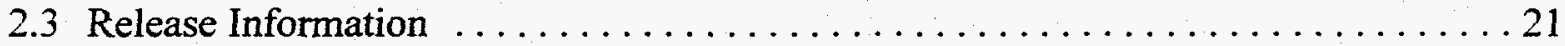

2.4 Investigative Background $\ldots \ldots \ldots \ldots \ldots \ldots \ldots \ldots \ldots \ldots \ldots \ldots \ldots \ldots \ldots \ldots \ldots \ldots \ldots \ldots \ldots, 22$

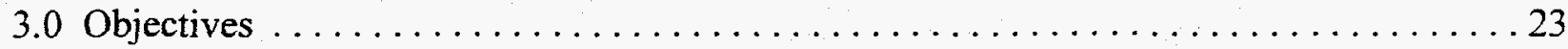

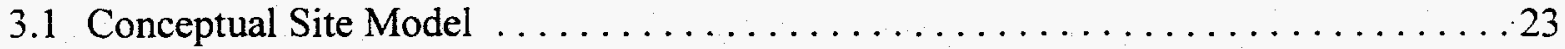

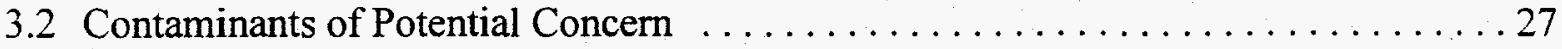




\section{Table of Contents (Continued)}

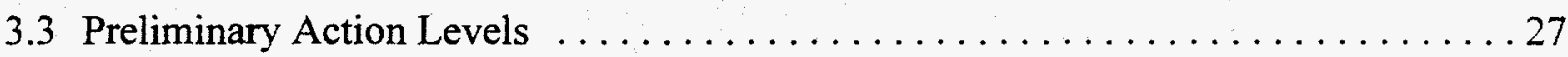

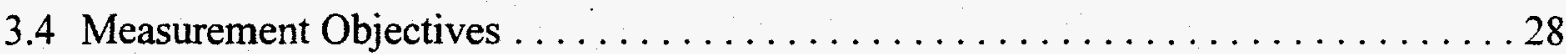

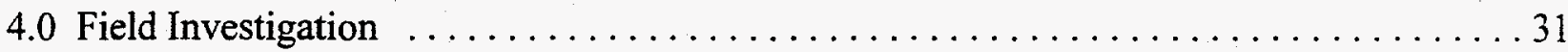

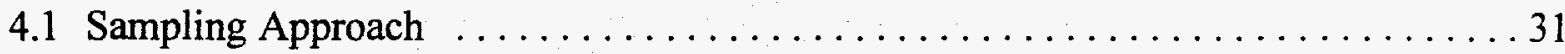

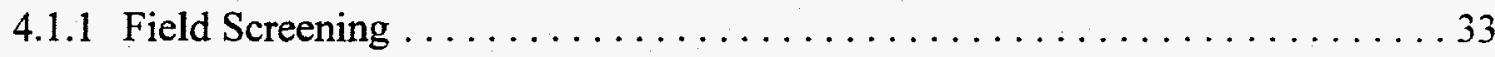

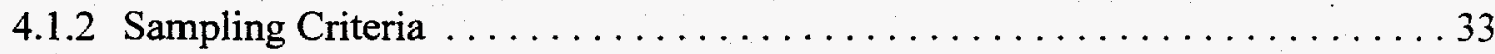

4.1 .3 Stop Points for Notification $\ldots \ldots \ldots \ldots \ldots \ldots \ldots \ldots \ldots \ldots \ldots \ldots \ldots \ldots \ldots \ldots \ldots \ldots$

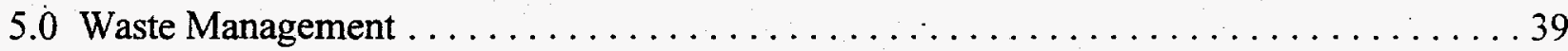

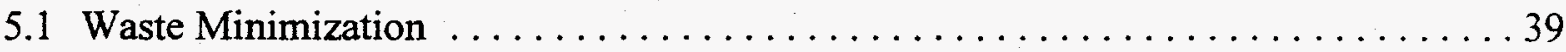

5.2 Potential Waste Streams . . . . . . . . . . . . . . . . . . 39

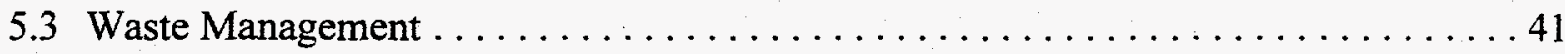

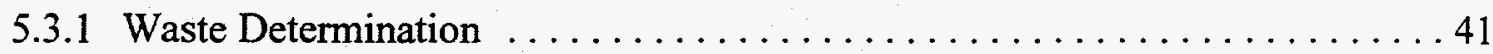

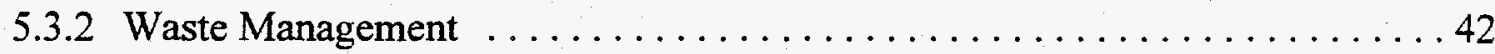

6.0 Time Frame and Records Availability $\ldots \ldots \ldots \ldots \ldots \ldots \ldots \ldots \ldots \ldots \ldots \ldots \ldots$

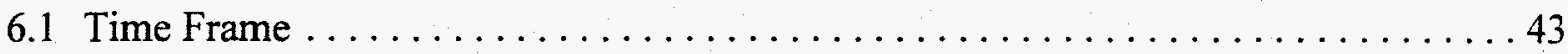

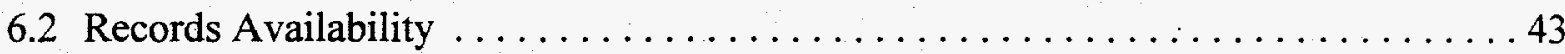

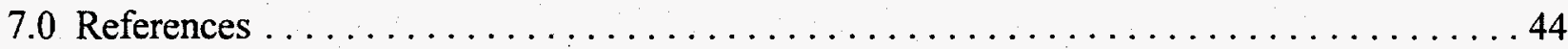

Appendix A - Data Quality Objective Worksheet $\ldots \ldots \ldots \ldots \ldots \ldots \ldots \ldots \ldots \ldots$

Appendix B - Nevada Environmental Restoration Project Document Review Sheet, Nevada

Division of Environmental Protection Comments and Responses . . . . . . . . B-1

Appendix C - Geophysical Survey-Result Figures $\ldots \ldots \ldots \ldots \ldots \ldots \ldots \ldots \ldots \ldots$ C-1 


\section{List of Figures}

Number

Title

Page

1-1 Tonopah Test Range Location Map .2

1-2 Location of the Area 3 Landfill Complex at the Tonopah Test Range ......... 3

2-1 Site Layout and Planned Borehole Locations, Landfills A3-1 and A3-2, Area 3 Landfill Complex, Tonopah Test Range $\ldots \ldots \ldots \ldots \ldots \ldots \ldots$

2-2 Site Layout and Planned Borehole Locations, Landfill A3-3, Area 3 Landfill Complex, Tonopah Test Range

2-3 Site Layout and Planned Borehole Locations, Landfill A3-4, Area 3 Landfill Complex, Tonopah Test Range

2-4 Site Layout and Planned Borehole Locations, Landfill A3-5, Area 3 Landfill Complex, Tonopah Test Range 14

2-5 Site Layout and Planned Borehole Locations, Landfill A3-6, Area 3 Landfill Complex, Tonopah Test Range 16

2-6 Site Layout and Planned Borehole Locations, Landfill A3-7, Area 3 Landfill Complex, Tonopah Test Range

2-7 Site Layout and Planned Borehole Locations, Landfill A3-8, Area 3 Landfill Complex, Tonopah Test Range

3-1 Conceptual Site Model for the Area 3 Landfill Complex 25

3-2 Conceptual Transverse Cross Sectional View of a Typical Landfill Cell with Borehole at the Area 3 Landfill Complex 


\section{List of Figures (Continued)}

Number

4-1 Generalized Decision Logic for Corrective Action Site Sampling 34

4-2 Schematic of the Core Barrel Sampler . 


\section{List of Plates}

Plate 1 - Area 3 Landfill Complex and Planned Borehole Locations, Tonopah Test Range

\section{List of Tables}

Number

Title

Page

3-1 Site Characterization Laboratory Analytical Requirements $\ldots \ldots \ldots \ldots \ldots \ldots$

4-1 Soil Engineering Analytical Requirements for Geotechnical Studies at the Area 3 Landfill Complex CASs ...................... 31

5-1 Action Levels for IDW Contaminants 


\section{List of Acronyms and Abbreviations}

bgs Below ground surface

CADD Corrective Action Decision Document

CAIP . Corrective Action Investigation Plan

CAS Corrective Action Site(s)

CAU Corrective Action Unit(s)

CFR Code of Federal Regulations

$\mathrm{Cs}^{137} \quad$ Cesium

DOE/NV U.S. Department of Energy, Nevada Operations Office

DOE U.S. Department of Energy

DOT U.S. Department of Transportation

DQO Data Quality Objective(s)

$\mathrm{Du} \quad$ Depleted uranium

EPA U.S. Environmental Protection Agency

EQL Estimated Quantitative Limit

ERD Environmental Restoration Division

ERP Environmental Restoration Project

FFACO Federal Facility Agreement and Consent Order

$\mathrm{ft} \quad$ Foot (feet)

GPR Ground Penetrating Radar

HASP Health and Safety Plan

IDW Investigation-derived waste

IT IT Corporation

LLW Low-level radioactive waste

$\mathrm{m}$ Meter(s)

$\mathrm{mg} / \mathrm{kg}$ Milligram(s) per kilogram

$\mathrm{mg} / \mathrm{L} \quad$ Milligram(s) per liter

NAC Nevada Administrative Code

NAS National Academy of Science

NDEP Nevada Division of Environmental Protection

NTSWAC Nevada Test Site Waste Acceptance Criteria

ORERP Off-Site Radiation Exposure Review Project 


\begin{tabular}{ll} 
PCB & Polychlorinated biphenyl(s) \\
PPE & Personal Protective Equipment \\
ppm & Part(s) per million \\
PRG & Preliminary Remediation Goal(s) \\
Pu $239 / 240$ & Plutonium \\
QA/QC & Quality assurance and quality control \\
QAPP & Quality Assurance Project Plan \\
RCRA & Resource Conservation and Recovery Act \\
RPD & Relative percent difference \\
SNL & Sandia National Laboratories \\
SVOC & Semivolatile organic compound(s) \\
TBD & To be determined \\
TC & Toxicity characteristic \\
TPH & Total petroleum hydrocarbon(s) \\
TTR & Tonopah Test Range \\
U 238 & Uranium \\
VOC & Volatile organic compound(s) \\
$\mu \mathrm{g} / \mathrm{L}$ & Microgram(s) per kilogram \\
$\% R$ & Percent recovery \\
\hline
\end{tabular}




\subsection{Introduction}

This Correction Action Investigation Plan (CAIP) has been developed in accordance with the Federal Facility Agreement and Consent Order (FFACO) that was agreed to by the U.S. Department of Energy, Nevada Operations Office (DOE/NV), the State of Nevada Division of Environmental Protection (NDEP), and the U.S. Department of Defense. The CAIP is a document that provides or references all of the specific information for planning investigation activities associated with Corrective Action Units (CAUs) or Corrective Action Sites (CASs) (FFACO, 1996).

This CAIP contains the environmental sample collection objectives and the criteria for conducting site investigation activities at the Area 3 Landfill Complex, CAU No. 424, which is located at the Tonopah Test Range (TTR). The TTR, included in the Nellis Air Force Range, is approximately 255 kilometers (140 miles) northwest of Las Vegas, Nevada (Figures 1-1 and 1-2). The CAU 424 is comprised of eight individual landfill sites that are located around and within the perimeter of the Area 3 Compound (DOE/NV,1996a). Plate 1 presents the location of each CAS with respect to the Area 3 Compound. Each landfill cell has been designated as a separate CAS and assigned a CAS Number; the numbers and corresponding site names are presented in Table 3-1 of the Corrective Action Unit Work Plan, Tonopah Test Range, Nevada (hereafter referred to as the TTR Work Plan) (DOE/NV, 1996a).

\subsection{Purpose}

The landfill cells associated with CAU No. 424 were excavated to receive waste generated from the daily operations conducted at the Area 3 Compound (DOE/NV, 1996a), and they were operated during different time intervals spanning from before 1963 to approximately 1993. Due to the unregulated disposal activities commonly associated with early landfill operations, an investigation will be conducted at each CAS to complete the following tasks:

- Identify the presence and nature of possible contaminant migration from the landfills.

- Determine the vertical and lateral extent of possible contaminant migration.

- Ascertain the potential impact to human health and the environment.

- Provide sufficient information and data to develop and evaluate appropriate corrective action strategies for each CAS. 


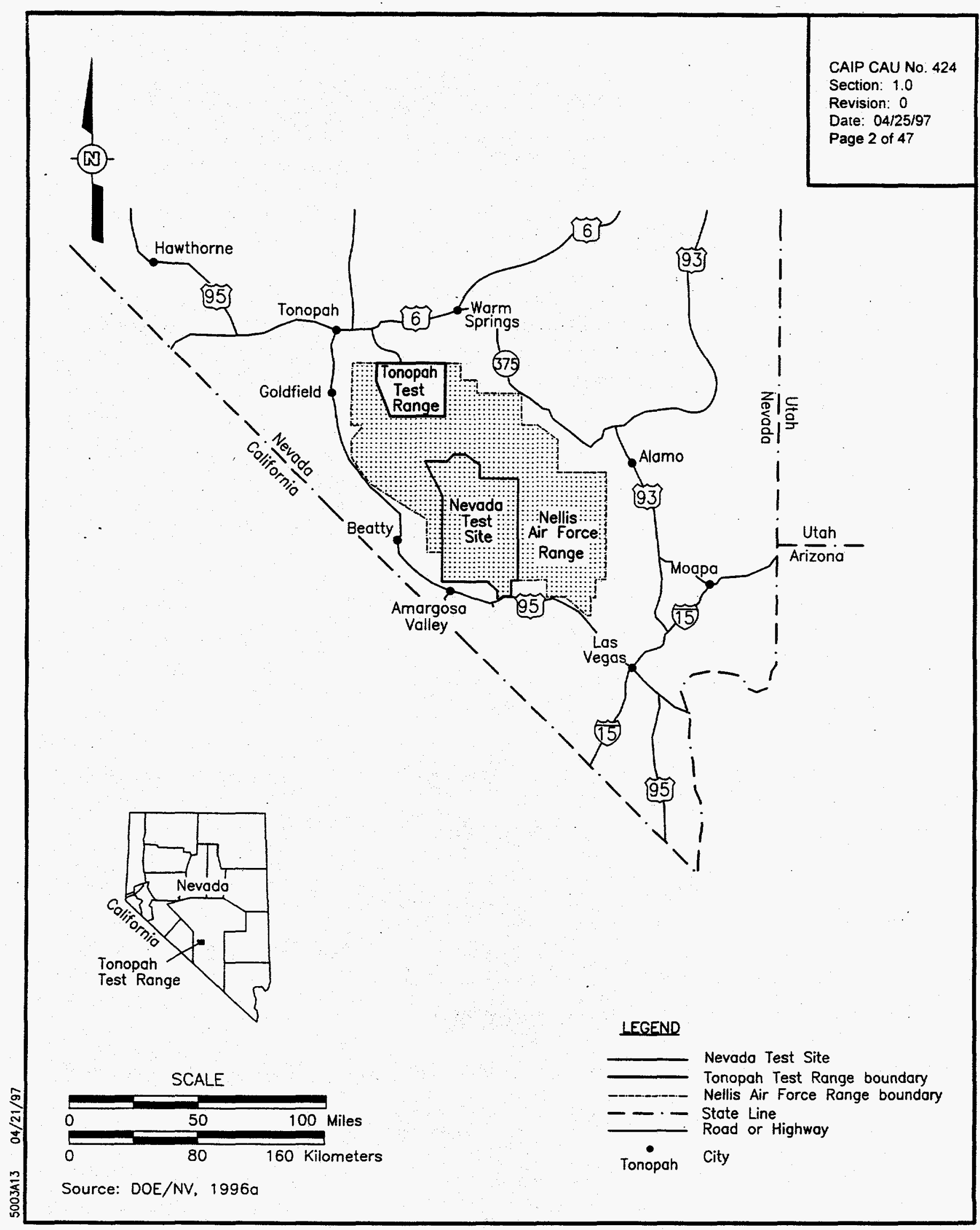

Figure 1-1

Tonopah Test Range Location Map 


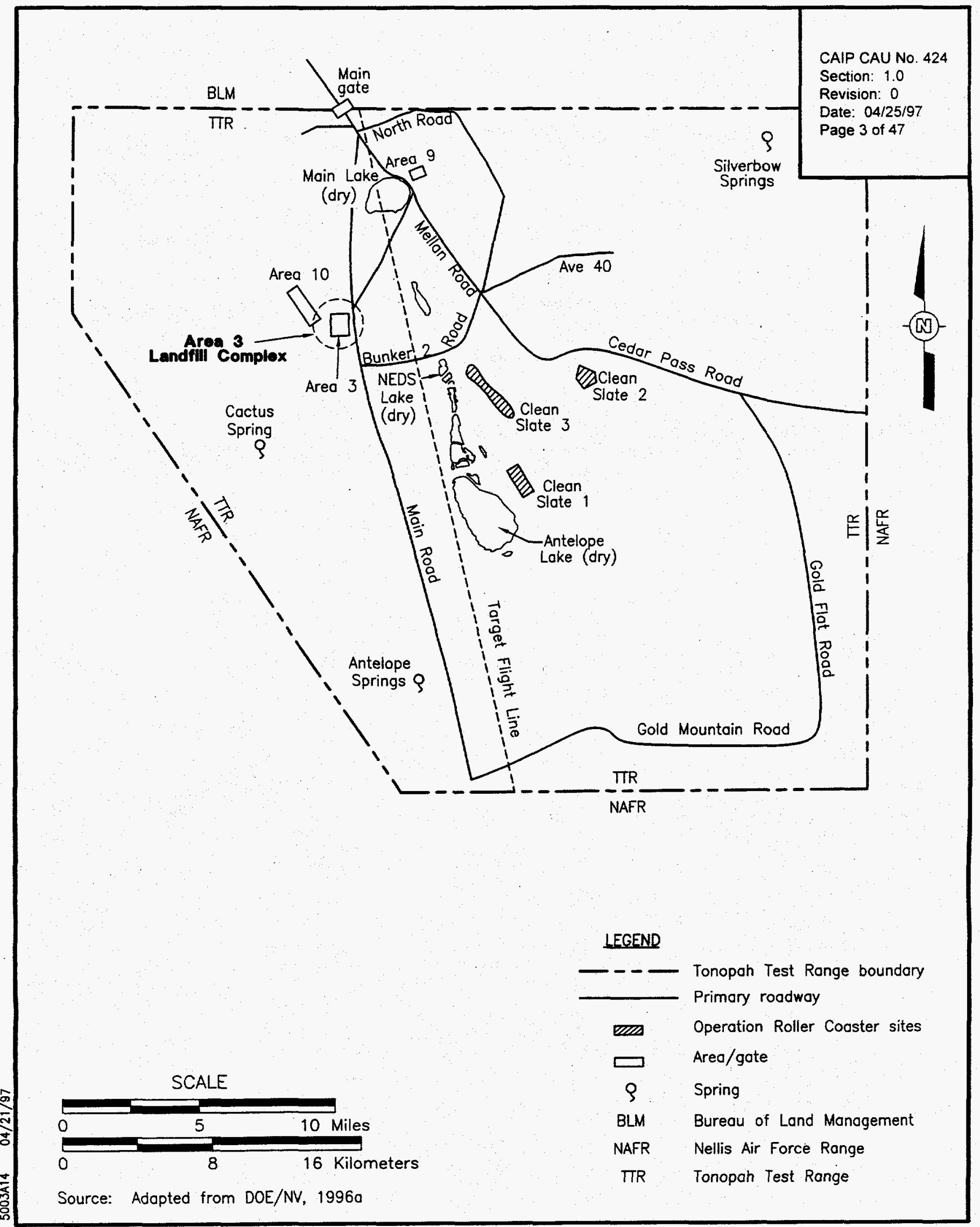

Figure 1-2

Location of the Area 3 Landfill Complex

at the Tonopah Test Range 
This CAIP was developed using the U.S. Environmental Protection Agency (EPA) Data Quality Objectives (DQO) (EPA, 1994) process to clearly define the purpose(s) for which environmental data will be used and to design a data collection program that will satisfy these goals. A summary of the results of the DQO process is presented in a worksheet format as Appendix A of this plan. The NDEP reviewed the draft version of the CAIP and made comments (see Appendix B). These comments were responded to accordingly and were incorporated as required.

\subsection{Scope}

The scope of this investigation includes the following:

- Drilling characterization boreholes using the dry sonic drilling method at each CAS

- Conducting continuous field screening

- Collecting environmental samples for laboratory and geotechnical analysis

- Logging core to assess soil and waste characteristics

The drilling locations will be biased toward the areas most likely to be contaminated based on an interpretation of geophysical data.

\subsection{CAIP Contents}

Section 1.0 of this CAIP provides an introduction to this project, including the purpose and scope for this corrective action investigation. The FFACO requires that CAIPs address the following elements:

- Management

- Technical aspects

- Quality assurance

- Health and safety

- Public involvement

- Field sampling

- Waste management

The managerial aspects of this project are discussed in the DOE/NV Environmental Restoration Project (ERP) Project Management Plan, Rev. 0 (DOE/NV, 1994a). The technical aspects of this CAIP are contained in the TTR Work Plan (DOE/NV, 1996a) and in Sections 2.0 and 3.0 of this document. General field and laboratory quality assurance and quality control (QA/QC) issues are presented in the Industrial Sites Quality Assurance Project Plan (QAPP) 
(DOE/NV, 1996b; DOE/NV, 1994b), and the specific aspects of field QA/QC are discussed in approved procedures. The health and safety aspects of this project are documented in the Environmental Restoration Project Health and Safety Plan (HASP) (DOENNV, 1994c) and will also be supplemented with a site-specific HASP written prior to commencement of field work. No CAU-specific public involvement activities are planned at this time; however, an overview of public involvement is documented in the draft "Public Involvement Plan" in Appendix V of the FFACO (1996). Field sampling activities are discussed in Section 4.0 of this CAIP. Waste management issues are discussed in the TTR Work Plan (DOE/NV, 1996a) and in Section 5.0 of this CAIP. The project schedule and records availability information are discussed in Section 6.0 of this CAIP, and a complete set of project references is provided in Section 7.0 of this CAIP. 


\subsection{Facility Description}

CAU 424 is comprised of eight, individual landfills (or CASs) that were operated during different time frames ranging from prior to 1963 until approximately 1993. The process knowledge and the information that is currently available to assess the individual landfills were examined during the DQO process (Appendix A). This information includes geophysical surveys, historical aerial photographs, TTR reports, and interviews with former TTR workers. From the standpoint of site conditions and operational history, sufficient information is available to address each CAS individually, and this information is presented in Sections 2.1.1 through 2.1.8 of this report. However, specific details concerning the waste inventory and release information are limited, but are generally similar for all sites. Therefore, the sites will be addressed collectively with interpretive assumptions presented in Sections 2.2 and 2.3.

General background information pertaining to the history of TTR and the Area 3 Compound, a geologic assessment, and an overview of the area hydrogeology including depths to groundwater are provided in the TTR Work Plan (DOE/NV, 1996a).

\subsection{Site Assessment and Operational History}

The site assessment and operational history for each CAS was determined from interpretations of historical aerial photographs (see Attachment A of Appendix A for a listing of aerial photographs) and surface geophysical studies (Appendix C; IT, 1996; IT, 1997).

\subsubsection{Landfill A3-1 (CAS No. 03-08-001-A3-01)}

Landfill A3-1 is located approximately 260 meters $(\mathrm{m})$ (850 feet [ft]) north-northwest of the northwest corner of the Area 3 Compound perimeter fence (see Plate 1 for site location). This site was identified through historical aerial photograph interpretation (see Attachment $A$ of Appendix A for a listing of aerial photographs) and was found to consist of four buried cells, one open and ramped trench located south of the four buried cells (A3-1a), and one large surface depression scattered with pieces of asphalt and concrete located next to the four buried cells (see Figure 2-1 for site map).

Using the dates of the historical aerial photographs, it is estimated that Landfill A3-1 began operation sometime before 1980 and was closed prior to 1982 . In a 1980 aerial photograph, the open and ramped trench was fenced on three sides and appears to have been used to burn trash 


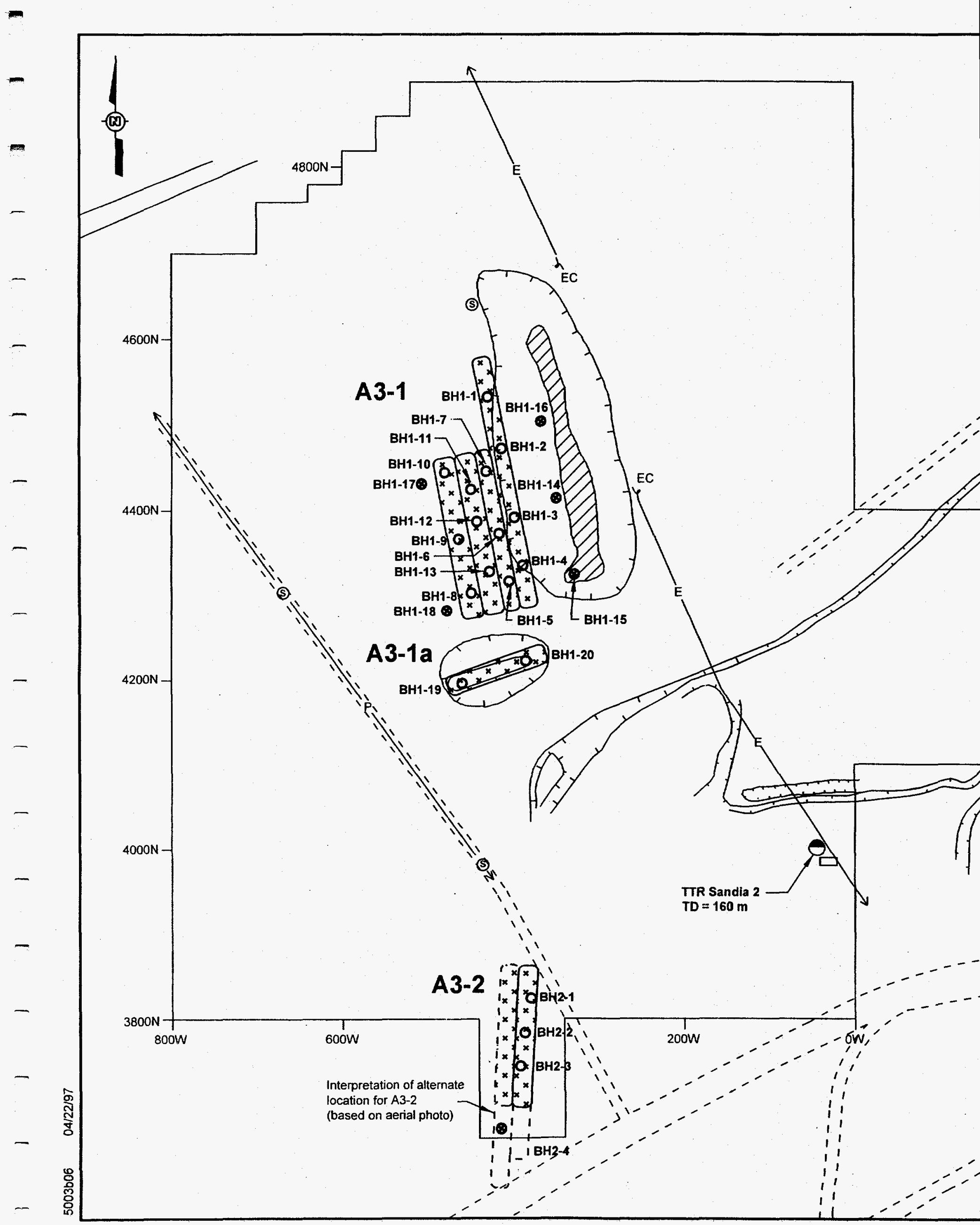



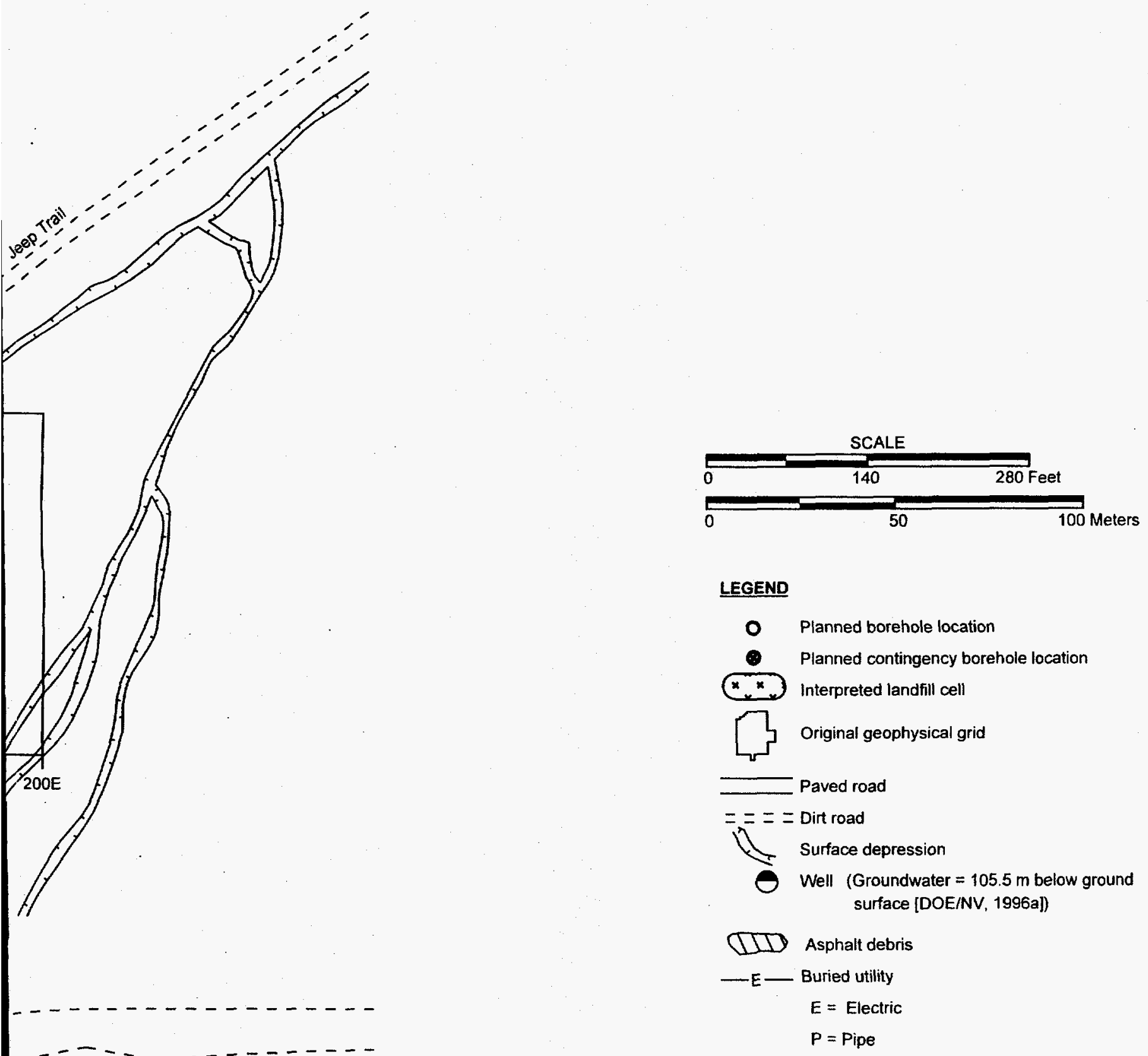

EC Cable at surface

(S) Sewer manhole

Figure 2-1

Site Layout and Planned Borehole Locations, Landfills A3-1 and A3-2, Area 3 Landfill Complex Tonopah Test Range 
(see Attachments A and C of Appendix A for a listing of aerial photographs and an operational time frame). In more recent aerial photographs, 1982 and later, the fence is gone and the sides appear to have been caved in; however, the trench was not completely filled in and appears as a depression. This information is presented as Attachment A to the Data Quality Objectives attached as Appendix A.

The locations of the four buried cells, the open trench, and the surface depression were verified by a geophysical survey conducted by IT Corporation in 1993 (IT, 1997). The four buried cells are elongated along an approximate north-south axis and are situated subparallel to one another. The approximate dimensions of three of the four cells are $4.6 \mathrm{~m}(15 \mathrm{ft})$ wide by $61 \mathrm{~m}(200 \mathrm{ft})$

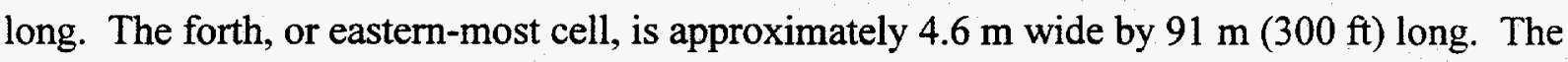

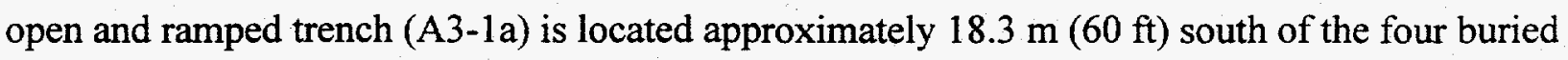
cells and is elongated along an approximate east-west axis (IT, 1997).

Geophysical survey results indicate that the depth to the top of debris in the two western buried cells is approximately 0.2 to $0.5 \mathrm{~m}(0.5$ to $1.5 \mathrm{ft})$ (IT, 1997). Depth to debris within the eastern two cells was not determined during geophysical survey activities; however, it is assumed to be similar to that found for the two western cells. Geophysical survey results of A3-1a indicated two small buried metallic anomalies. It is believed that this trench will contain mostly burned debris or ash; however, there is the potential for other solid waste to have been disposed of as well. Survey results and associated figures can be found in the Initial Surface Geophysical Survey Report for the Tonopah Test Range Environmental Restoration Sites, Volume 1 of 2, March, 1994 (IT, 1997); a representative example of the geophysical results is found in Appendix B. There is no geophysical information to indicate the vertical extent of the cells or trench; therefore, the bases of the cells and trench are assumed to be approximately $3.0 \mathrm{~m}(10 \mathrm{ft})$ to $4.6 \mathrm{~m}(15 \mathrm{ft}$ ) below ground surface (bgs). This assumption is based on an analogy from a similar disposal trench, the North Disposal Trench, located on the TTR at the Roller Coaster Lagoons (DOE/NV, 1996c).

\subsubsection{Landfill A3-2 (CAS No. 03-08-002-A3-02)}

Landfill A3-2 is located approximately $106.7 \mathrm{~m}$ (350 ft) south of A3-1a (the open trench at site A3-1) (see Plate 1 for site location). This site was discovered during geophysical survey activities conducted for Landfill A3-1. The geophysical data indicated buried metallic materials resembling a covered landfill cell. Because the site was situated along the south edge of the 
survey area, the survey grid was subsequently expanded to include the full extent of A3-2.

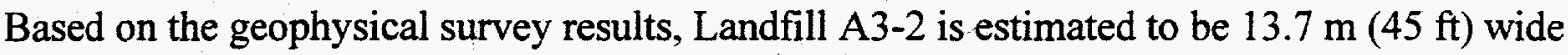
by $51.8 \mathrm{~m}$ (170 ft) long (IT, 1997); however, aerial photos indicate the cell could be longer (see Figure 2-1 for site map). There is no geophysical information to indicate the vertical extent

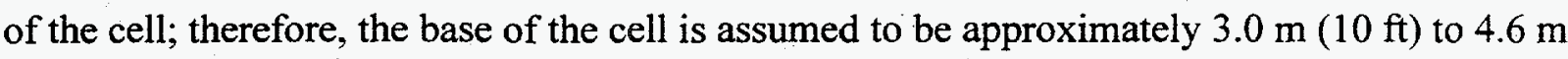
(15 ft) below ground surface. This assumption is also based on an analogy from the North Disposal Trench (DOE/NV, 1996c); Appendix C contains a representative example of the geophysical results for Landfill A3-2.

Historical aerial photos were examined to identify the presence, location, and operational time frame of landfill cell A3-2 (see Attachment A of Appendix A for a listing of aerial photographs). The landfill was not present on 1982 and earlier aerial photographs. The landfill was identified as a single, open cell on a 1985 aerial photograph and shown to be closed on later photographs dated 1986 to 1993 . It is, therefore, inferred to have been open during a short time frame from approximately 1983 to 1985 (see Attachments A and C of Appendix A for a listing of aerial photographs and an operational time frame).

\subsubsection{Landfill A3-3 (CAS No. 03-08-003-A3-03)}

The results of geophysical surveys conducted in 1993 (IT, 1997) and in 1996 (IT, 1996) revealed the presence of buried metallic materials resembling a covered landfill cell. The site is located within the current Area 3 Compound fenced perimeter, approximately $50 \mathrm{~m}(164 \mathrm{ft})$ north of the TTR west gate along a portion of the west-bounding fence line (see Plate 1 for site location and Figure 2-2 for site map). This CAS consists of two, subparallel, linear cells that trend in an approximate north-northeast orientation along the fence line. Also included in the CAS are approximately two, small, semicircular cells (pits) located approximately $50 \mathrm{~m}$ (164 ft) east of the fence line. The lateral dimensions of the cells are interpreted from geophysical data to be the

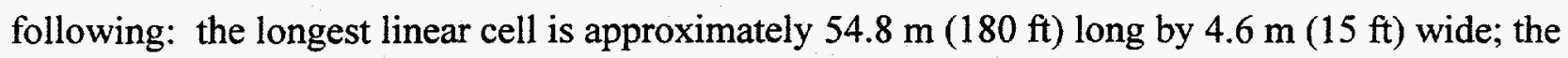
second linear cell is approximately $36.6 \mathrm{~m}$ (120 ft) long by $4.6 \mathrm{~m}(15 \mathrm{ft})$ wide; the semicircular cells are approximately $7.6 \mathrm{~m}(25 \mathrm{ft})$ by $3.0 \mathrm{~m}(10 \mathrm{ft})$ in size (see Appendix C for the example of the geophysical results). There is no geophysical information to indicate the vertical extent of the linear cells; therefore, the base of the linear cells is assumed to be approximately $3.0 \mathrm{~m}$ ( $10 \mathrm{ft}$ )

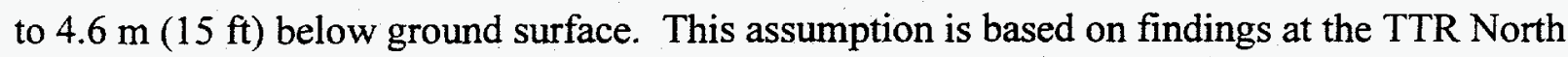
Disposal Trench (DOE/NV, 1996c). The semicircular cells may not be as deep. There are no visible surface features that indicate the presence of the landfill cells. 


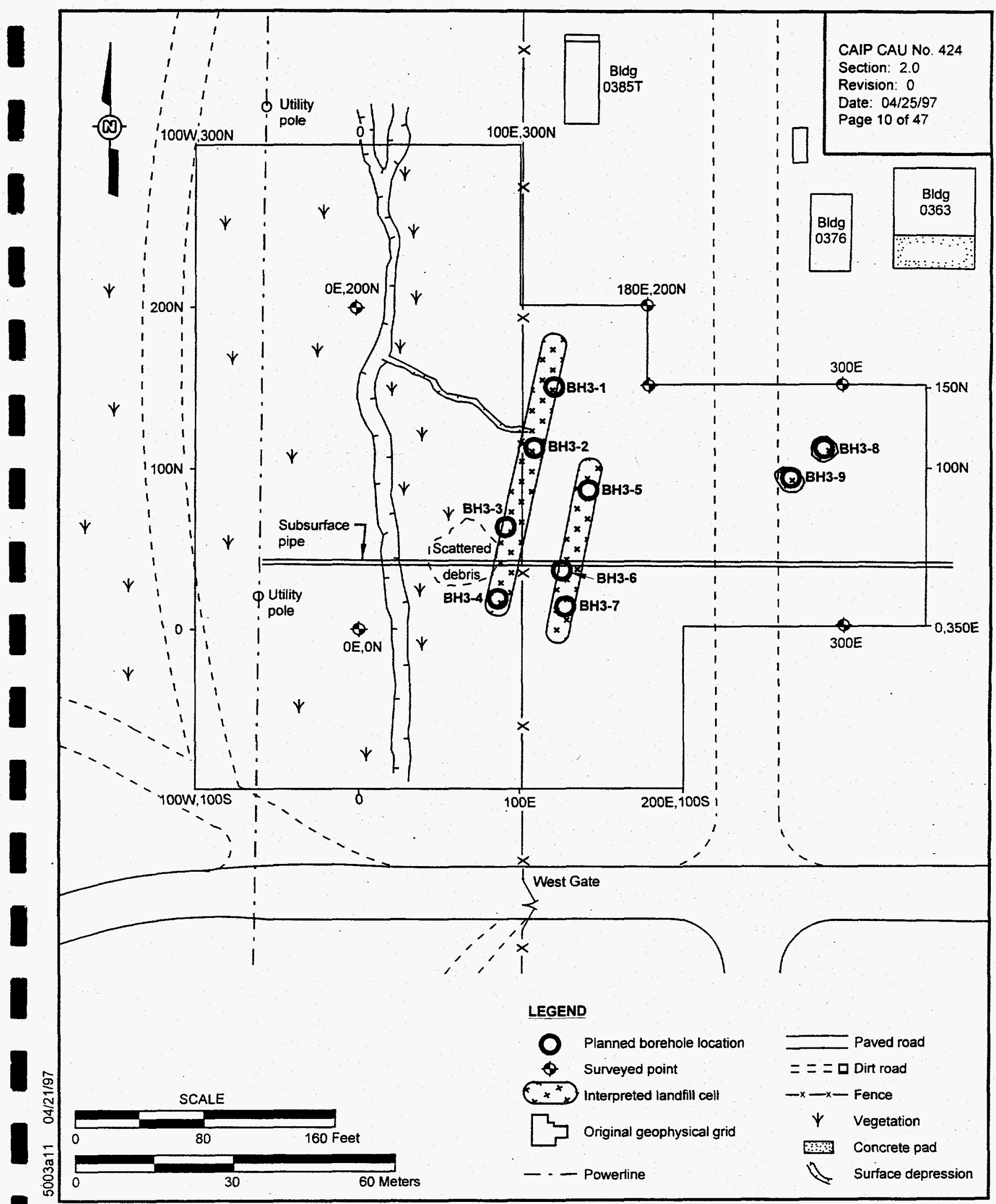

Figure 2-2

Site Layout and Planned Borehole Locations, Landfill A3-3

Area 3 Landfill Complex, Tonopah Test Range 
The portion of the site located within the Area 3 perimeter fence is currently used for either surface storage (i.e., trailers, generators, heavy equipment) or is heavily trafficked.

Historical aerial photos were examined to identify the presence, location, and operational time frame of landfill cell A3-3 (see Attachments A and C of Appendix A for a listing of aerial photographs and an operational time frame). None of the photos gave a clear indication of the presence or location of the landfill; they did, however, provide subjective evidence as to the operational time frame for the cell. The later photos (1980s and 1990s) (see Attachment A of Appendix $\mathrm{A}$ for a listing of aerial photographs) all indicated that the landfill location was coincident with a heavily trafficked and used area (i.e., parked trailers and stored construction materials) which is not conducive for an open landfill. The photos dating from around 1962 (see Attachment A of Appendix A for a listing of aerial photographs) and earlier revealed that the cell area was located in a large area of disturbed soil just west of a zone designated for future building expansion (information from a TTR report infers that Area 3 underwent a major period of expansion during the 1962 time frame [SNL, 1992]). This implies that the A3-3 landfill cell probably was in service during the early years of the Area 3 Compound, prior to the inferred expansion that occurred in 1962.

\subsubsection{Landfill A3-4 (CAS No. 03-08-004-A3-04)}

Landfill A3-4 is located approximately $470 \mathrm{~m}(1,542 \mathrm{ft})$ south southwest of the southwest corner of the Area 3 Compound perimeter fence (see Plate 1 for site location). This site was identified through historical aerial photograph interpretation. The western-most cell was observed to be partially open on a 1982 photograph (see Attachment A of Appendix A for a listing of aerial photographs). In a more recent aerial photograph (1993) (see Attachments A and C of Appendix A for a listing of aerial photographs and an operational time frame), all the cells are covered with soil, and subsidence is evident in the area of the cells.

A geophysical survey was performed at this location in 1993 (IT, 1997) (see Appendix C for an example of the geophysical results). The site was found to consist of two buried cells and one buried pit, all varying in size (see Figure 2-3 for site map). The two buried cells are elongated along an approximate north-south axis. The western-most cell is approximately $143.3 \mathrm{~m}$ by $13.7 \mathrm{~m} \mathrm{(} 470 \mathrm{ft}$ by $45 \mathrm{ft}$ ) in size; the other cell is approximately $61.0 \mathrm{~m}$ by $9.1 \mathrm{~m}(200 \mathrm{ft}$ by $30 \mathrm{ft}$ ); and the pit is approximately $15.2 \mathrm{~m} \mathrm{(50} \mathrm{ft)} \mathrm{in} \mathrm{diameter} \mathrm{(IT,} \mathrm{1997).} \mathrm{The} \mathrm{buried} \mathrm{pit} \mathrm{is} \mathrm{located}$ under the airport road, and the two buried cells are located south of the airport road. Surface 


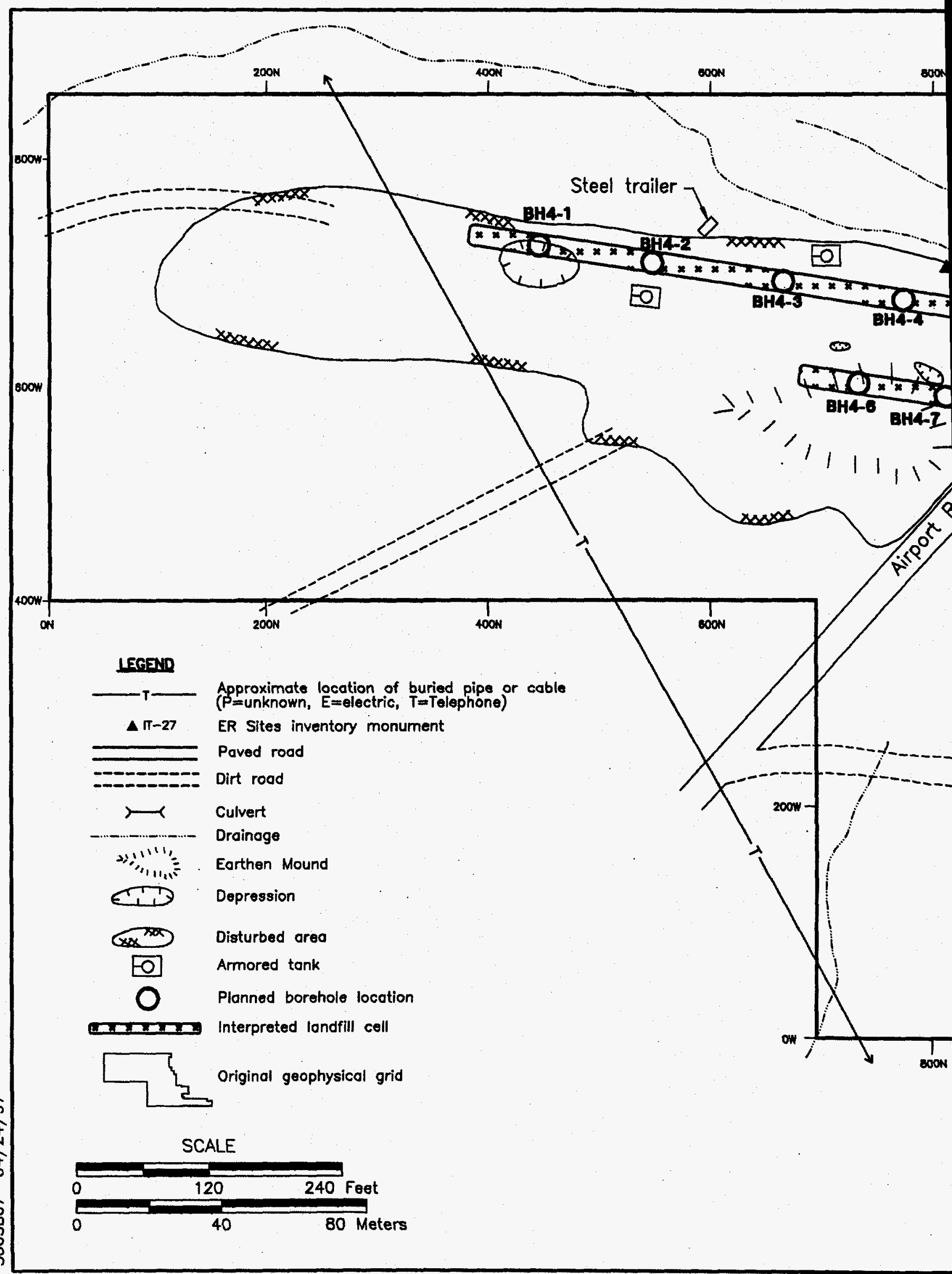




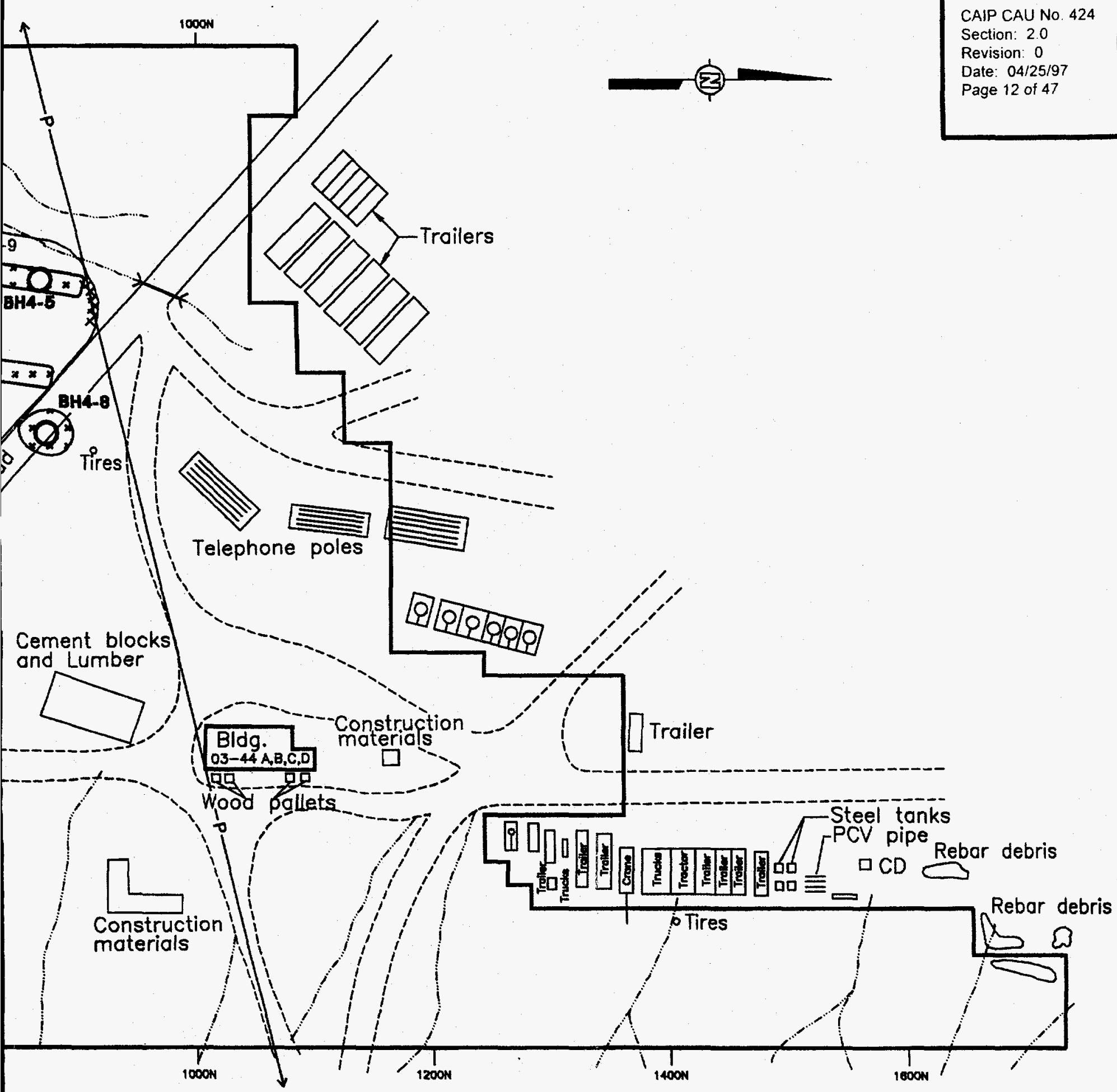

Figure 2-3 
expression of the elongated cells is evident on a 1993 aerial photograph (see Attachment A of Appendix A for list of aerial photographs). There is no geophysical information to indicate the vertical extent of the cells or pit; therefore, the bases of the cells and pit are assumed to be approximately $3.0 \mathrm{~m}(10 \mathrm{ft})$ to $4.6 \mathrm{~m}(15 \mathrm{ft})$ below ground surface. This assumption is based information from the North Disposal Trench located on the TTR (DOE/NV, 1996c).

\subsubsection{Landfill A3-5 (CAS No. 03-08-005-A3-05)}

Landfill A3-5 was first identified from a 1962 aerial photograph (see Attachment A of Appendix A) and was subsequently verified using surface geophysical methods (IT, 1996). The site is located within the current fenced boundary of Area 10, approximately $45 \mathrm{~m}(148 \mathrm{ft})$ west-northwest of the southeast corner of the Area 10 perimeter fence (see Plate 1 for location and Figure 2-4 for site map). A subtle, oblong-shaped, surface mound corresponds with the interpreted location of the buried cell. The geophysical interpretation reveals one, linear, northsouth trending cell in the subsurface (see Appendix $\mathrm{C}$ for an example of the geophysical survey results). The interpreted lateral dimensions of the cell are approximately $30.5 \mathrm{~m}(100 \mathrm{ft})$ long by

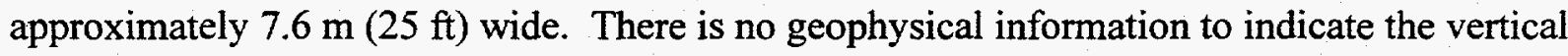
extent of the cell; therefore, the bottom of the cell is assumed to be approximately $3.0 \mathrm{~m}(10 \mathrm{ft})$

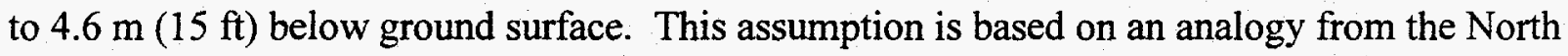
Disposal Trench (DOE/NV, 1996c).

Historical aerial photos were examined to identify the operational time frame of landfill cell A3-5. The landfill is clearly indicated as a single, linear, open cell containing unidentifiable debris on a 1962 aerial photo (see.Attachments A and C of Appendix A for a listing of aerial photographs and an operational time frame). The landfill cell appears to be related to a westward trending succession of north-south oriented landfills that were excavated and subsequently filled with debris and trash during the early years of the Area 3 Compound. The A3-5 landfill postdates the A3-3 and A3-6 landfills and represents the western-most extension of the series of landfills. Based on the approximate age of the photo, 1962 (see Attachment A of Appendix A for a listing of aerial photographs), the A3-5 landfill cell was in service during a period of expansion (inferred from SNL, 1992) of the Area 3 Compound. 


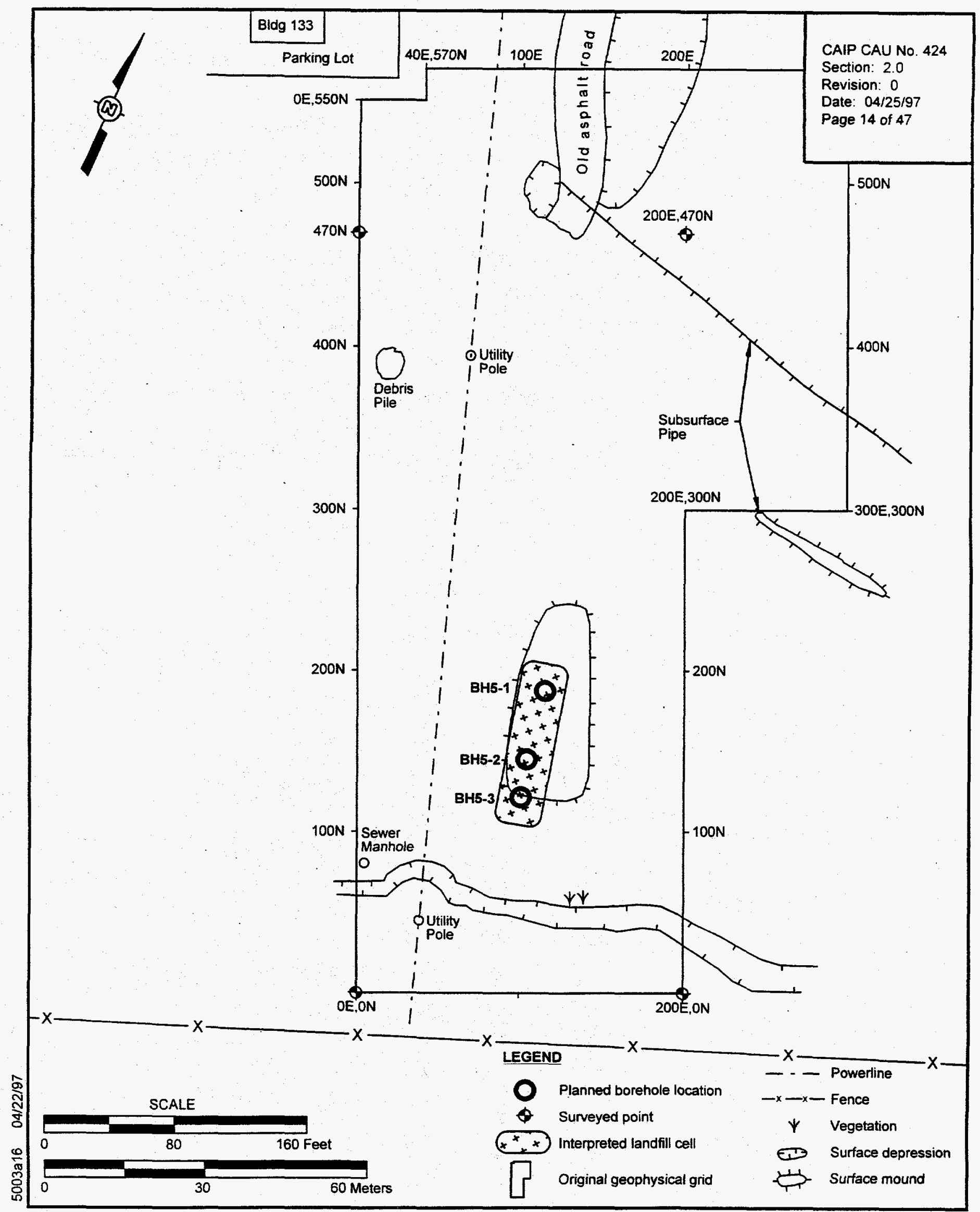

Figure 2-4

Site Layout and Planned Borehole Locations, Landfill A3-5 Area 3 Landfill Complex, Tonopah Test Range 


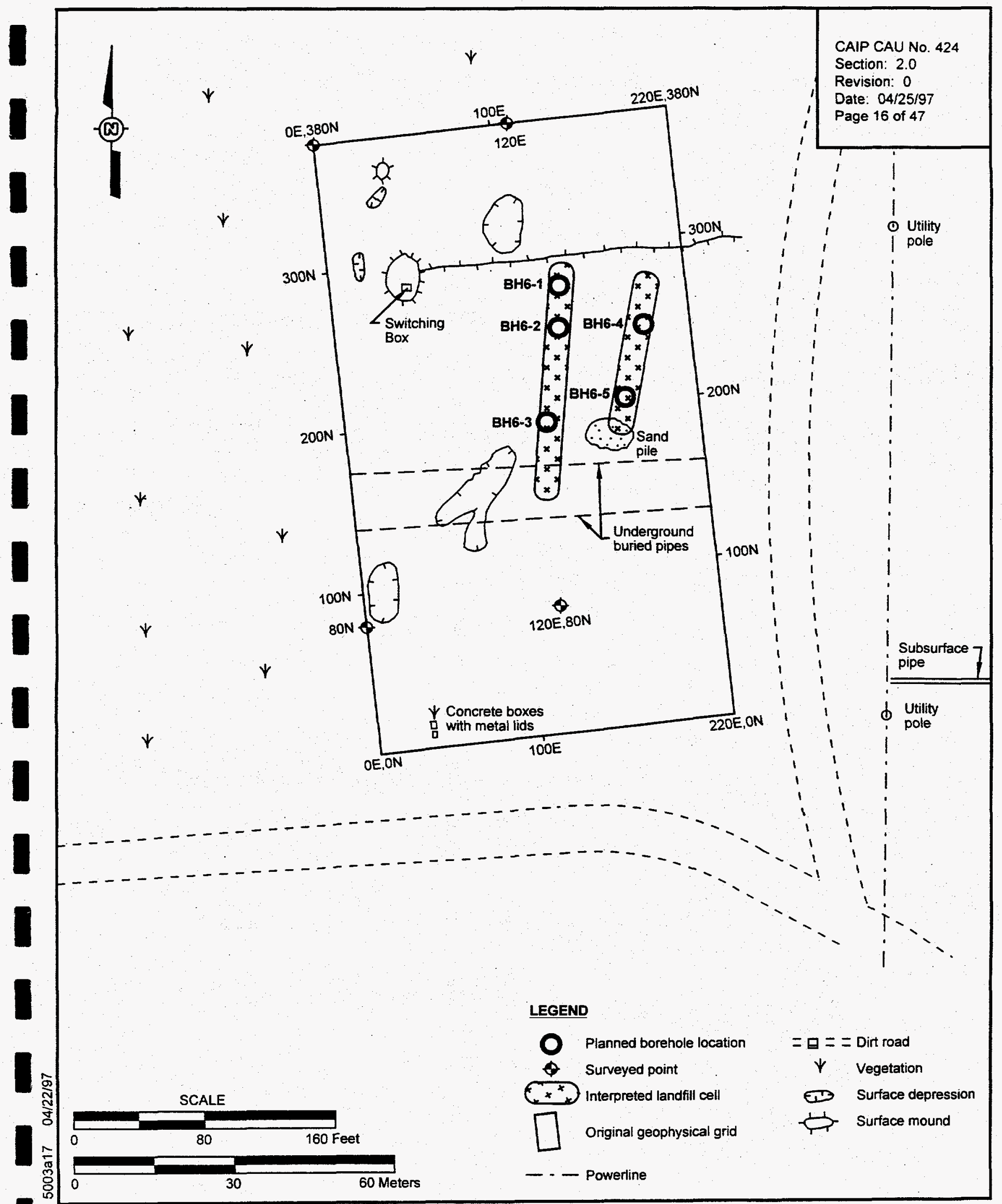

Figure 2-5

Site Layout and Planned Borehole Locations, Landfill A3-6 Area 3 Landfill Complex, Tonopah Test Range 


\subsubsection{Landfill A3-6 (CAS No. 03-08-006-A3-06)}

Landfill A3-6 was first identified from an historical aerial photograph taken in 1962

(see Attachment A of Appendix A for aerial photograph listing) and subsequently verified using surface geophysical methods (IT, 1996). The site is located approximately $150 \mathrm{~m}(492 \mathrm{ft})$ northwest of the west gate of the Area 3 Compound, approximately midway between the southeast corner of the Area 10 fenced perimeter and the west fence of the Area 3 compound (see Plate 1 for location and Figure 2-5 for site map). A small, slight depression on the ground surface corresponds with the interpreted location of the buried cells at the site. The geophysical interpretation reveals two, linear, subparallel, north-northeast trending cells in the subsurface (see Appendix $\mathrm{C}$ for an example of the geophysical results). The interpreted lateral dimensions indicate the cell lengths to be approximately $44.2 \mathrm{~m}(145 \mathrm{ft})$ and $32 \mathrm{~m}(105 \mathrm{ft})$; the cell widths appear to be similar at approximately $4.6 \mathrm{~m}(15 \mathrm{ft})$. There is no geophysical information to indicate the vertical extent of the cells; therefore, the base of the cells is assumed to be approximately $3.0 \mathrm{~m}(10 \mathrm{ft})$ to $4.6 \mathrm{~m}(15 \mathrm{ft})$ below ground surface. This assumption is based on an analogy from the North Disposal Trench at the Roller Coaster Lagoons (DOE/NV, 1996c).

Historical aerial photos were examined to identify the presence, location, and operational time frame of landfill cell A3-6 (see Attachments A and C of Appendix A for a listing of aerial photographs and an operational time frame). The outline of the landfill appears on an historical aerial photo taken sometime in 1962 (see Attachment A of Appendix A). On this photo, it appears to have been recently closed as indicated by a conspicuous, linear-shaped, north-south trending area of disturbed soil. The landfill cell is interpreted to be related to a westward trending succession of north-south oriented landfills that were excavated and subsequently filled with debris and trash during the early years of the Area 3 Compound. The A3-6 landfill appears to post-date the A3-3 landfill and pre-date the A3-5. It is believed that landfill A3-6 contains construction debris generated during the expansion activities (inferred from SNL, 1992) at the Area 3 Compound.

\subsubsection{Landfill A3-7 (CAS No. 03-08-007-A3-07)}

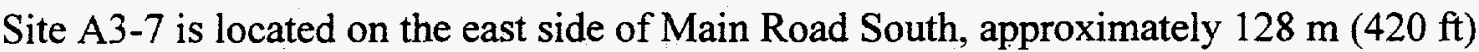
east-northeast of the Area 3 main gate (see Plate 1 for location and Figure 2-6 for site map). This site was originally identified as a possible landfill area based on a conspicuous area of disturbed soil observed on historical aerial photos (see Attachment A of Appendix A for aerial photograph listing). Results from recent geophysical surveys (IT,1996), however, do not support the likelihood that the disturbed soil represents a typical landfill complex. Magnetic anomalies and 


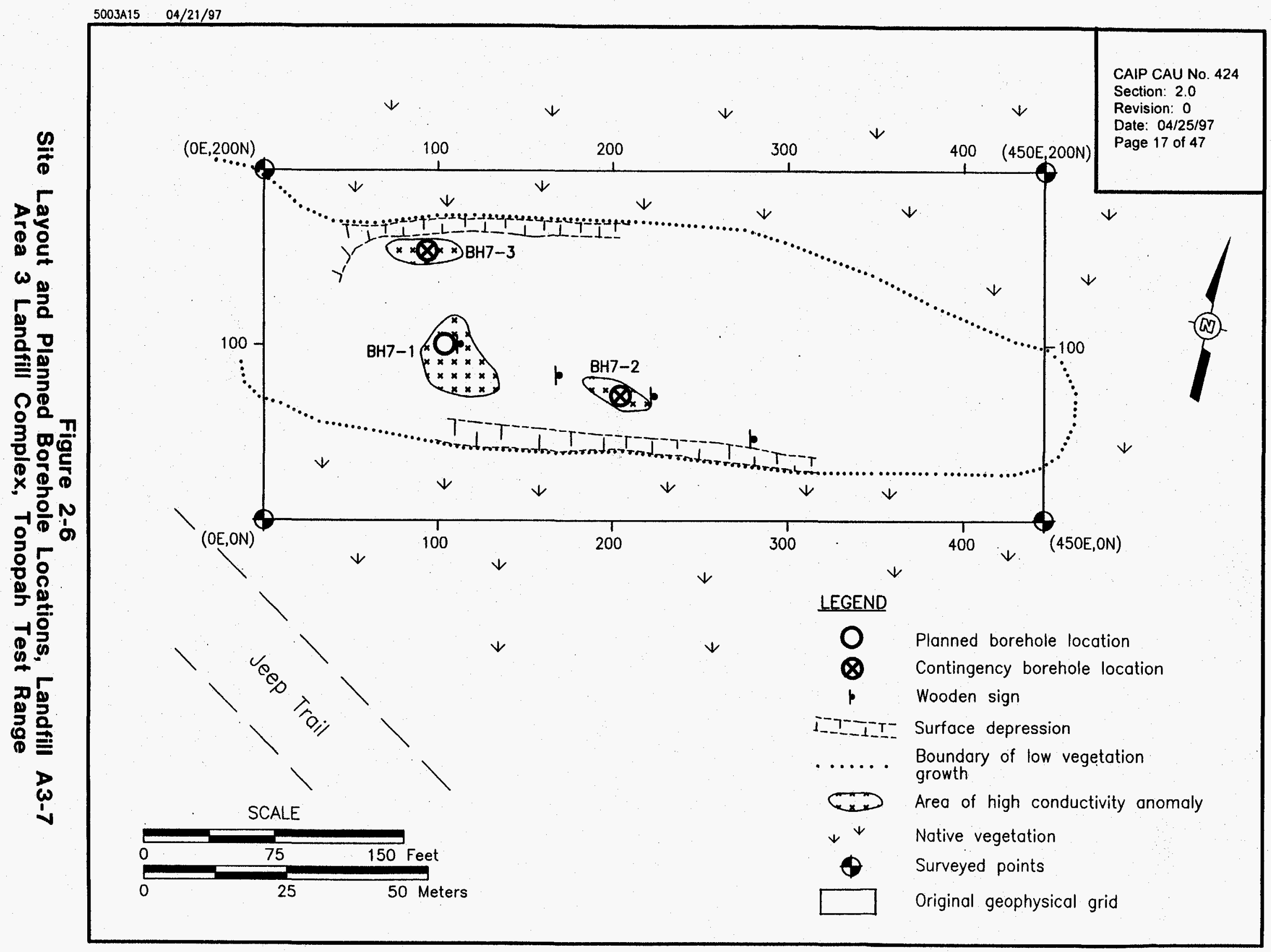


other distinguishing characteristics (i.e., oriented linear geometry) commonly associated with Area 3 landfill cells were not present within the area of disturbed soil. The geophysical data did contain three, oblong-shaped conductivity anomalies that coincide with the disturbed soil area. These anomalies are interpreted to be associated with soil or materials which become more conductive with depth. The largest conductivity anomaly is approximately $15 \mathrm{~m}(40 \mathrm{ft})$ along the axis and $10 \mathrm{~m}(33 \mathrm{ft})$ in diameter. An example of the geophysical survey results is included in Appendix C.

A review of the historical aerial photographs indicate that the disturbed soil area was originally cleared sometime before or during 1962 (see Attachment A of Appendix A for a listing of aerial photographs). Wooden signs, posted along the center of the disturbed soil area, are no longer legible but infer that material could be buried at the site. Although there is no clear explanation for the reason the area was cleared, the conductivity anomalies and presence of signs suggest intrusion and perhaps burial of nonmetallic materials (i.e., road rock salt [Quas, 1993]).

\subsubsection{Landfill A3-8 (CAS No. 03-08-008-A3-08)}

Landfill A3-8 is located approximately $185 \mathrm{~m}(607 \mathrm{ft})$ south-southwest of the southwest corner of the Area 3 Compound perimeter fence (see Plate 1 for site location). This site was identified from an oblique aerial photograph taken in 1962 (see Attachment A of Appendix A). The site was originally believed to be an east-west oriented trench visible in the photograph. The area identified from the aerial photograph has since been filled in, graded, and is currently being used as an equipment storage yard. Stored in this area are several boxcars used for equipment storage and miscellaneous items such as tires, spools of cable, concrete blocks, large gun turrets, and miscellaneous wood items.

A geophysical survey consisting of magnetic, electromagnetic, and Ground Penetrating Radar (GPR) was conducted in 1996 in this area around and between the rows of boxcars. The survey results identified metallic anomalies resembling covered landfill cells located south-southeast and north of the boxcars (IT, 1996) (see Appendix C for an example of the geophysical survey results). The GPR survey was conducted around, between, east, and southeast of the boxcars, and the results confirmed that an east-west trending trench does not exist below the boxcars as originally believed. After further inspection of the photograph, the shape of the east-west trench appears to have been designed for some purpose other than a landfill (i.e., has three vertical sides with a ramp down into it, similar to a truck loading ramp). The south-southeast anomalies appear to be three to four sub-parallel trenches elongated along a southwest-northeast axis with 
the western one or two trenches extending northeast under the southeastern most boxcars. Each trench is approximately $4.6 \mathrm{~m}(15 \mathrm{ft})$ wide by $57.9 \mathrm{~m}(190 \mathrm{ft})$ long (see Figure $2-7$ for site map). This set of anomalies is not the east-west oriented trench mentioned previously, but is located in the area of a southwest-northeast trending trench visible in the 1962 aerial photograph (see Attachment A of Appendix A).

The northern anomaly is located in an area north of stockpiled gravel (see Figure 2-7). The area has scattered gravel on it. The anomaly could be the result of mafic rocks; however, it is being included for investigation because the 1962 aerial photograph (see Attachment A of Appendix A) shows ground disturbance in this area as well. The anomaly north of the boxcars appears to be one buried cell elongated along a north-south axis and is approximately $15.2 \mathrm{~m}(50 \mathrm{ft})$ wide by $30.5 \mathrm{~m} \mathrm{(100} \mathrm{ft)} \mathrm{long.} \mathrm{There} \mathrm{is} \mathrm{no} \mathrm{geophysical} \mathrm{information} \mathrm{to} \mathrm{indicate} \mathrm{the} \mathrm{vertical} \mathrm{extent} \mathrm{of} \mathrm{the}$ any of the detected trenches; therefore, the bases of the trenches are assumed to be approximately $3.0 \mathrm{~m}(10 \mathrm{ft})$ to $4.6 \mathrm{~m}(15 \mathrm{ft})$ below ground surface. This assumption is based on an analogy from the North Disposal Trench at the TTR Roller Coaster Lagoons (DOE/NV, 1996c).

\subsection{Waste Inventory}

The available process knowledge is not sufficient to specify the waste inventory for each individual landfill cell. Therefore, the waste inventory will be discussed on a collective basis for all the landfill cells.

Information from interviews with former TTR workers (Appendix A, Section I.C) and analysis of historical photographs (see Attachments A and C of Appendix A for a listing of aerial photographs and an operational time frame) and TTR operations (DOE/NV, 1996a) indicate that municipal-type trash, including construction debris and office trash, constitute the primary components of the Area 3 landfills. Resource Conservation and Recovery Act (RCRA)-regulated constituents are not expected to be a primary component of the landfills because liquid drains were available in most of the buildings to segregate solid vs. liquid wastes (i.e., solvents) (DOE/NV, 1996a); improved waste management procedures were probably in place in the late 1980 s and 1990s; and there are no reports of hazardous wastes being disposed of in the landfills. 


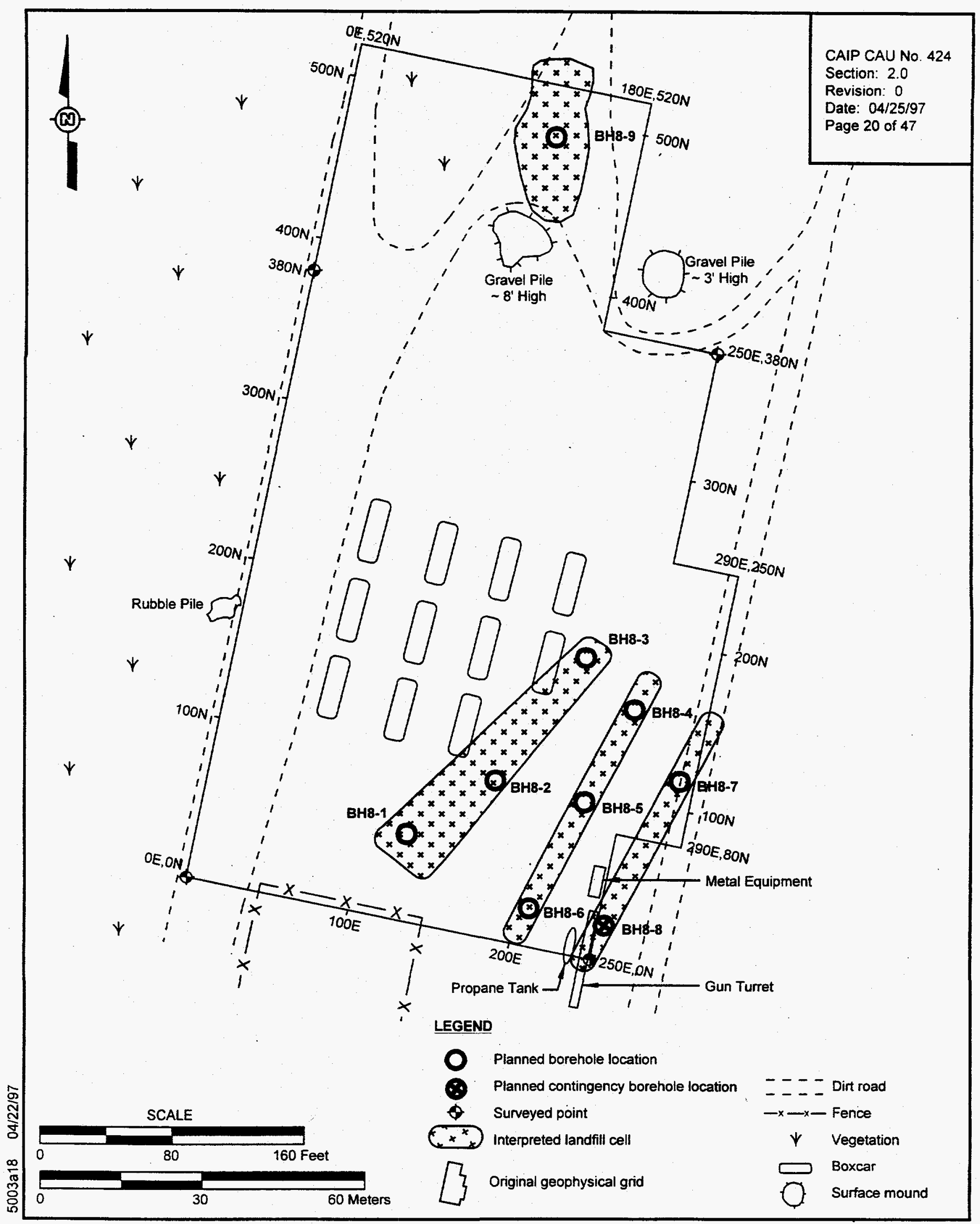

Figure 2-7

Site Layout and Planned Borehole Locations, Landfill A3-8 Area 3 Landfill Complex, Tonopah Test Range 
If, however, RCRA-regulated wastes are present in the landfill cells, they would probably be associated with the activities and operations that were conducted in the Area 3 shops (outlined in the DQOs [Appendix A]) and would be limited in volume (due to reasons stated in the previous paragraph).

Reports from TTR workers also indicate that small quantities of rat poison (Appendix A, Section I.C) and rock salt from road deicing activities (Quas, 1993) may be present in the Area 3 landfills. The potential also exists for small quantities of depleted uranium (DU) to be present in the landfills based on one personal interview (Appendix A, Section I.C). This possibility is deemed unlikely because, in a separate interview with a former worker, it was mentioned that radioactive material from tests of mock nuclear ordnance was routinely collected and buried near the point of impact on the target area (Karas, 1993a).

\subsection{Release Information}

Historic information indicates that the primary waste components buried in the landfill cells are probably solid, rather than liquid materials. These solid materials include construction debris, office trash, and other components of municipal-type trash.

There is no evidence to suggest that large volumes of liquids were disposed of in the landfill. cells. However, if any liquids have been disposed of in the landfills and/or have been released, they are probably in small amounts. The premise for this is based on the likelihood that large volumes of liquids would have been disposed of down the sewer system rather than transported to the landfills. Liquids typically associated with the various shops (see Attachment $E$ of Appendix A for list of TTR shops) that support TTR daily operations include waste oil, grease, paints, solvents, gasoline, diesel fuel, and cleaning supplies (Attachment D of Appendix A).

If contamination has been released in the landfill cells, the contaminant migration would probably be limited to within approximately the first $7.6 \mathrm{~m}(25 \mathrm{ft})$ below ground surface in the unsaturated soil, below the bottom of the cells. This premise is based on three points. First, there is a high likelihood that the alluvial soils have low unsaturated hydraulic conductivities; second, there is no driving force (i.e., low precipitation); and third, source material quantities are small if present. 


\subsection{Investigative Background}

There have been two geophysical surveys conducted around the Area 3 Compound to identify and delineate the landfill complexes. The first survey was conducted in July and November of 1993 (IT, 1997). The second survey was compitied in September of 1996 (IT, 1996). Both surveys provided data from which the landfill cell geometries were interpreted. One example of definitive geophysical data for each site is included as Appendix C. 


\subsection{Objectives}

The sampling objectives were determined using the DQO process outlined by the EPA in their Guidance for the Data Quality Objectives Process (EPA, 1994). The DQOs are qualitative and quantitative statements that specify the quality of the data required to support potential courses of action for the landfill cells. The DQOs were developed to clearly define the purpose(s) for which environmental data will be used and to design a data collection program that will satisfy these goals. One tool used in the DQO process is the formulation of site conceptual models.

\subsection{Conceptual Site Model}

A conceptual model has been developed to postulate exposure pathways from potential contaminant sources at the landfills: The model is based on assumptions and premises that were discussed during the DQO process and outlined in the DQO worksheet (Appendix A). If the conceptual model is proven incorrect from the results of environmental sampling, then NDEP will be notified and the site rescoped. The following summarizes the primary assumptions that were included in the DQOs (Appendix A) and considered in formulating the site conceptual model:

- The wastes disposed of in the landfills are nonhazardous, solid wastes similar to that found in municipal landfills. Construction debris and office trash constitute a majority of the waste volume based on interviews with former employees (Appendix A, Section I.C) and historical aerial photographs (see Attachment A of Appendix A for listing of aerial photographs).

- Construction material waste from the extensive building expansion that is inferred to have occurred in the early 1960s (SNL, 1992) probably accounts for a majority of the solid waste disposed of in the older landfill cells (A3-3, A3-5, A3-6, and A3-8).

- Improved waste management practices in the late 1980 s and early 1990 s limit the potential for hazardous materials in the later trenches (A3-1, A3-1a, and A3-4).

- The presence of sewer/septic system lines and underground discharge points in the Area 3 Compound reduce the possibility that liquids were disposed of in the landfills.

- There is no positive evidence verifying disposal of hazardous or RCRA materials in the landfill cells. 
- If hazardous materials were disposed of in the landfills, the Constituents of Concern would be based on the activities of the shops and facilities operating within the Area 3 Compound (Karas, 1993b) and their potential to contribute hazardous materials to the landfills.

- Future use of the area is likely to be similar to current use (remote locations or surface storage); however, Landfills A3-2, A3-3, A3-5, and A3-6 may be in the pathway for speculated future expansion.

- Groundwater is not thought to have been impacted because liquids were probably not disposed of in large quantities, if at all; depth to groundwater is extensive (greater than $91.1 \mathrm{~m}[300 \mathrm{ft}]$ [DOE/NV, 1996a]); and the environmental conditions at the site (i.e., arid climate, low permeabilities) are not conducive to downward migration.

- If contaminant migration is present, it will be limited to the soil beneath the landfill to a

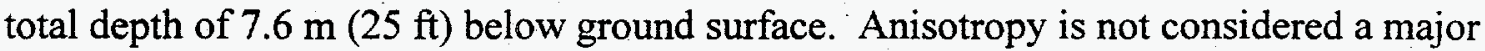
element for influencing migration.

- Excavation of contaminated material by site workers is the likely potential exposure pathway.

- The dry sonic drilling method is adequate to provide characterization sampling.

These assumptions were considered, and from them a conceptual model was created (Figure 3-1). It was conceptualized that the majority of the contents within the landfills is construction debris and office trash and that the primary contaminant source in the landfills would be from a small amount, if any, of solid and liquid materials generated from the maintenance shop activities in the Area 3 Compound and deposited in the landfills. The most likely area affected is located immediately beneath the trenches from approximately $3 \mathrm{~m}$ (approximate base of the landfills) to $7.6 \mathrm{~m}(10 \mathrm{ft}$ to $25 \mathrm{ft}$ ) below ground surface (Figure 3-2). In order to adequately assess the possibility of lateral migration (of possible contamination) due to anisotropy, soil characteristic information, including moisture content, will be collected during the investigation to determine if conditions exist that are conducive for lateral movement. If both contamination and anisotropic conditions are found to exist, NDEP will be notified and the project rescoped to account for lateral migration. 


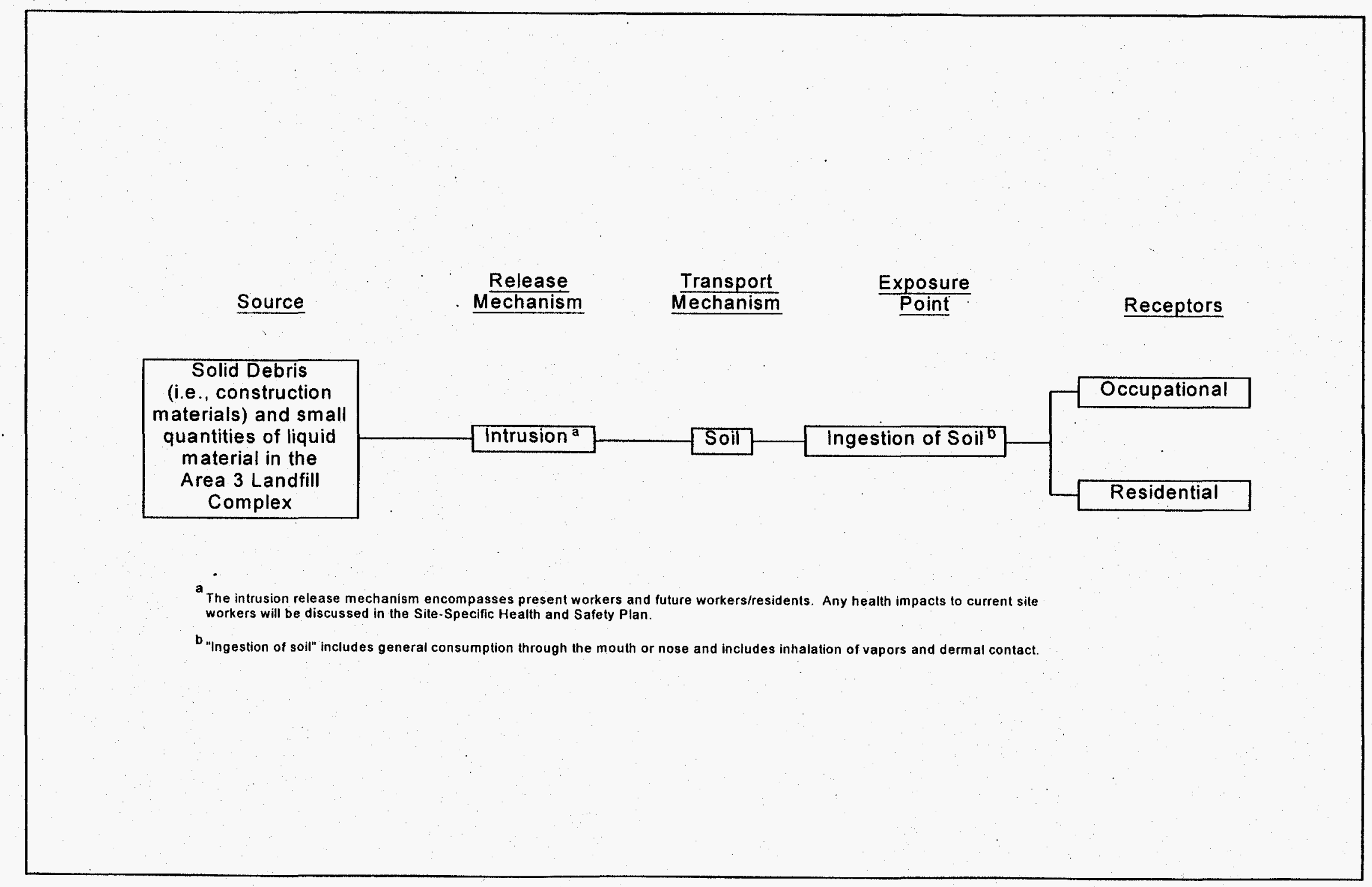

Figure 3-1

Conceptual Site Model for the Area 3 Landfill Complex 


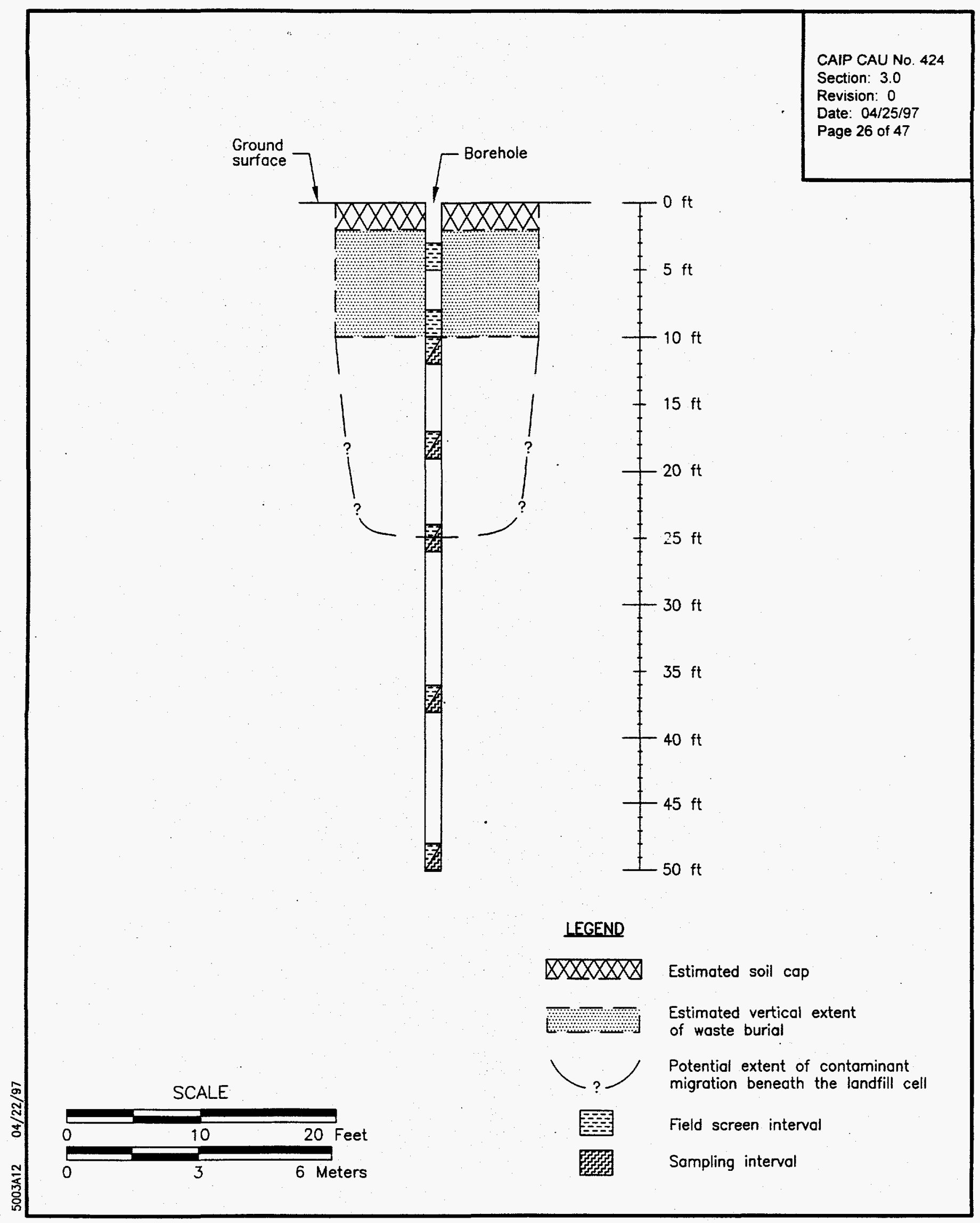

Figure 3-2

Conceptual Transverse Cross Sectional View of a

Typical Landfill Cell with Borehole at the Area 3 Landfill Complex 
The conceptual model indicates that the site has only a shallow soil source and one exposure route, ingestion of soil through the mouth or nose. Intrusion into the site (such as digging with a backhoe or drilling) could disturb the soil or unearth the waste and cause a release of contamination.

Site access is not restricted by fences or posted with signs, and the potential for inadvertent disturbance exists. If it is determined after sampling that groundwater may be impacted, the site may be rescoped, and the groundwater pathway will be investigated. The landfills are, however, not anticipated either to contain contaminants or to contain contaminants at concentrations greater than regulatory clean-up action levels; therefore, the likelihood of a significant groundwater impact is not anticipated. In addition, contamination, if present, is anticipated to be managed so that future migration of hazardous constituents is prevented.

\subsection{Contaminants of Potential Concern}

There is no evidence indicating disposal of hazardous or RCRA material in the landfills.

Potential types of contaminants that could be present are based on subjective process knowledge and inferred activities associated with the Area 3 Compound. Because the landfills operated at different times but had similar sources, all the landfills have the potential for the following contaminants of concern:

- Volatile organic compounds (VOCs)

- Semivolatile organic compounds (SVOCs)

- Inorganics (RCRA metals)

- Polychlorinated biphenyls (PCBBs)

- Pesticides - rat poison (Karas, 1993b)

- Total petroleum hydrocarbons (TPH) - oil filters (Karas, 1993b)

- Depleted Uranium (U $\mathrm{U}^{238}$ - (Karas, 1993c)

- Corrosives - batteries (Karas, 1993b; Karas 1993c)

\subsection{Preliminary Action Levels}

Preliminary action levels for both on-site field screening methods and off-site analytical methods will be used to determine the presence of contamination. All action levels were agreed upon during the DQO process. The following on-site action levels will be used:

- VOC screening levels at 20 parts per million (ppm) or 2.5 times background, whichever is higher 
- The analytical concentration of $100 \mathrm{ppm}$ TPH or a field screening concentration that is comparable to an analytical concentration of $100 \mathrm{ppm} \mathrm{TPH}$

- Radiation (alpha, beta/gamma) levels 2 times background levels

The preliminary action levels for the off-site laboratory analytical methods will be the values upon which decisions for future action for the landfills will be based. These preliminary action levels are as follows:

- EPA Region 9 Preliminary Remediation Goals (PRGs) (Smucker, 1996) or background concentrations (i.e., metals concentrations), whichever is higher, for initial site characterization. Risk-based levels based on modeling may be used as an alternative.

- 100 ppm TPH

- Background radiological levels or levels listed in the Offsite Radiation Exposure Review Project (ORERP), Phase II Soils Programs report (McArthur and Miller, 1989).

\subsection{Measurement Objectives}

Laboratory analysis of the soil samples will provide the means for a quantitative measurement of the potential contaminants of concern. The analytical methods and minimum reporting limits for each analyte are provided in Table $3-1$.

If environmental sample data indicate that no analytes are above the criteria presented in Table 3-1, then no further action or closure in place will be recommended. Modeling of the likelihood of future increases in contaminant concentrations may be required to assist in these recommendations and decisions. 
Table 3-1

Site Characterization Laboratory Analytical Requirements (Page 1 of 2)

\begin{tabular}{|c|c|c|c|c|c|}
\hline Analyte & Medium & $\begin{array}{l}\text { Analytical } \\
\text { Method }^{a}\end{array}$ & $\begin{array}{c}\text { Minimum } \\
\text { Reporting Limit }\end{array}$ & $\begin{array}{l}\text { Precision } \\
\text { (RPD) }\end{array}$ & $\begin{array}{c}\text { Accuracy }{ }^{b} \\
(\% R)\end{array}$ \\
\hline \multirow[t]{2}{*}{ Total VOCs } & Water & \multirow[t]{2}{*}{$8240^{c}$ or $8260^{c}$} & \multirow{2}{*}{$\begin{array}{l}\text { Analyte-specific } \\
\text { estimated } \\
\text { quantitation limits }^{d}\end{array}$} & 14 & $60-132$ \\
\hline & Soil & & & 24 & $59-172$ \\
\hline \multirow[t]{2}{*}{ Total SVOCs } & Water & \multirow[t]{2}{*}{$8270^{c}$} & \multirow{2}{*}{$\begin{array}{l}\text { Analyte-specific } \\
\text { estimated } \\
\text { quantitation limits }\end{array}$} & 50 & $5-230$ \\
\hline & Soil & & & 50 & $11-142$ \\
\hline $\begin{array}{l}\text { Total RCRA Metals } \\
\text { Arsenic } \\
\text { Barium } \\
\text { Cadmium } \\
\text { Chromium } \\
\text { Lead } \\
\text { Mercury } \\
\text { Selenium } \\
\text { Silver }\end{array}$ & Water & $6010 / 7470^{c}$ & $\begin{array}{c}10 \mu \mathrm{g} / \mathrm{L} \\
200 \mu \mathrm{g} / \mathrm{L} \\
5 \mu \mathrm{g} / \mathrm{L} \\
10 \mu \mathrm{g} / \mathrm{L} \\
3 \mu \mathrm{g} / \mathrm{L} \\
0.2 \mu \mathrm{g} / \mathrm{L} \\
5 \mu \mathrm{g} / \mathrm{L} \\
10 \mu \mathrm{g} / \mathrm{L}\end{array}$ & \multirow[t]{2}{*}{20} & \multirow[t]{2}{*}{$75-125$} \\
\hline $\begin{array}{l}\text { Arsenic } \\
\text { Barium } \\
\text { Cadmium } \\
\text { Chromium } \\
\text { Lead } \\
\text { Mercury } \\
\text { Selenium } \\
\text { Silver }\end{array}$ & Soil & $6010 / 7470^{c}$ & $\begin{array}{c}2 \mathrm{mg} / \mathrm{kg} \\
40 \mathrm{mg} / \mathrm{kg} \\
1 \mathrm{mg} / \mathrm{kg} \\
2 \mathrm{mg} / \mathrm{kg} \\
0.6 \mathrm{mg} / \mathrm{kg} \\
0.1 \mathrm{mg} / \mathrm{kg} \\
1 \mathrm{mg} / \mathrm{kg} \\
2 \mathrm{mg} / \mathrm{kg}\end{array}$ & & \\
\hline \multirow[t]{4}{*}{$\begin{array}{l}\text { Total Petroleum } \\
\text { Hydrocarbons }\end{array}$} & $\begin{array}{c}\text { Water } \\
\text { (gasoline) }\end{array}$ & \multirow[t]{4}{*}{8015 modified $^{c}$} & $1 \mathrm{mg} / \mathrm{L}$ & 20 & $25-145$ \\
\hline & $\begin{array}{l}\text { Water } \\
\text { (diesel) }\end{array}$ & & $1 \mathrm{mg} / \mathrm{L}$ & 20 & $25-145$ \\
\hline & $\begin{array}{c}\text { Soil } \\
\text { (gasoline) }\end{array}$ & & $1 \mathrm{mg} / \mathrm{kg}$ & 30 & $30-130$ \\
\hline & $\begin{array}{c}\text { Soil } \\
\text { (diesel) }\end{array}$ & & $30 \mathrm{mg} / \mathrm{kg}$ & 30 & $30-130$ \\
\hline \multirow{2}{*}{$\begin{array}{l}\text { Total } \\
\text { Pesticides/PCBs }\end{array}$} & Water & \multirow[t]{2}{*}{$8080^{c}$} & \multirow{2}{*}{$\begin{array}{l}\text { Analyte-specific } \\
\text { estimated } \\
\text { quantitation limits }\end{array}$} & 30 & $8-160$ \\
\hline & Soil & & & 50 & $8-139$ \\
\hline \multirow[t]{2}{*}{$\begin{array}{l}\text { Gamma } \\
\text { Spectroscopy }\end{array}$} & Water & $\begin{array}{c}\text { EPA } 901.1^{e} \text { or } \\
\text { LAL-91-SOP-0063i }\end{array}$ & \multirow{2}{*}{$\begin{array}{l}\text { Background levels } \\
\text { or } \\
\text { ORERPi }\end{array}$} & 20 & $80-120$ \\
\hline & Soil & $\begin{array}{l}\text { HASL } 300,4.5 .2 .3^{9} \text { or } \\
\text { LAL-91-SOP-0064 }\end{array}$ & & 20 & $80-120$ \\
\hline
\end{tabular}


Table 3-1

\section{Site Characterization Laboratory Analytical Requirements}

$$
\text { (Page } 2 \text { of 2) }
$$

\begin{tabular}{|c|c|c|c|c|c|}
\hline Analyte & Medium & $\begin{array}{l}\text { Analytical } \\
\text { Method }^{\mathrm{a}}\end{array}$ & $\begin{array}{c}\text { Minimum } \\
\text { Reporting Limit }\end{array}$ & $\begin{array}{l}\text { Precision }^{b} \\
\text { (RPD) }\end{array}$ & $\begin{array}{c}\text { Accuracy }^{\mathrm{b}} \\
(\% \mathrm{R})\end{array}$ \\
\hline \multirow{2}{*}{$\begin{array}{l}\text { Isotopic Uranium } \\
\left(U^{238}\right)\end{array}$} & Water & \multirow{2}{*}{$\begin{array}{l}\text { NAS-NS-3050 or } \\
\text { LAL-91-SOP-0108 }\end{array}$} & \multirow{2}{*}{$\begin{array}{l}\text { Background levels } \\
\text { or } \\
\text { ORERP }\end{array}$} & \multirow[t]{2}{*}{$25^{\prime}$ or 20} & \multirow{2}{*}{$\begin{array}{c}70-120 \text { or } \\
70-130\end{array}$} \\
\hline & Soil- & & & & \\
\hline \multirow{2}{*}{$\begin{array}{l}\text { Isotopic Plutonium } \\
\left(\mathrm{Pu}^{239 / 240}\right)\end{array}$} & Water & \multirow{2}{*}{$\begin{array}{l}\text { NAS-NS-3058 }{ }^{\mathrm{m}} \text { or } \\
\text { LAL- } 91-\text { SOP-0108 }\end{array}$} & \multirow{2}{*}{$\begin{array}{l}\text { Background levels } \\
\text { or } \\
\text { ORERP' }\end{array}$} & \multirow[t]{2}{*}{$25^{1}$ or 20} & \multirow{2}{*}{$\begin{array}{c}75-120^{\prime} \text { or } \\
80-120\end{array}$} \\
\hline & Soil & & & & \\
\hline
\end{tabular}

${ }^{a} \mathrm{QC}$ (water) samples are included in table.

${ }^{b}$ Precision and Accuracy requirements were obtained from the Resource Conservation and Recovery Act Industrial Sites Quality Assurance Project Plan, dated 1994 (DOE/NV, 1994b).

CEPA Test Methods for Evaluating Solid Waste, 3rd edition, Parts 1-4, SW-846 (EPA, 1992)

Estimated Quantitation Limit (EQL) as given in Method SW-846, U.S. EPA (EPA, 1992)

estandard Methods for the Examination of Water and Wastewater, American Public Health Association (APHA, 1992)

LAS Laboratory, 1996a, Standard Operating Procedures

${ }^{9}$ Environmental Measurements Laboratory Procedure Manual, HASL-300, U.S. Department of Energy (DOE, 1992a)

hLAS Laboratory, 1996b, Standard Operating Procedures

'Offsite Radiation Exposure Review Project (ORERP), Phase // Soils Program report (DOE/NV/10384-23) (McArthur and Miller, 1989)

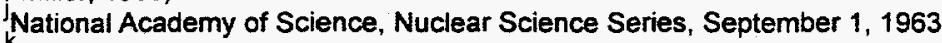

KLAS Laboratory, 1993, Standard Operating Procedures

Precision and Accuracy requirements were obtained from the Streamlined Approach for Environmental Restoration Plan, CAU No. 400: Bomblet Pit and Five Points Landfill (DOE/NV, 1996d).

$m$ National Academy of Science, Nuclear Science Series, September 1, 1962

$\begin{array}{ll}\text { VOC }=\text { Volatile organic compound(s) } & \text { SVOC }=\text { Semivolatile organic compound(s) } \\ \mathrm{mg} / \mathrm{kg}=\text { Milligram(s) per kilogram } & \text { PCB }=\text { Polychlorinated biphenyl(s) } \\ \mathrm{U}=\text { Uranium } & \mathrm{RPD}=\text { Relative Percent Difference } \\ \mathrm{Pu}=\text { Plutonium } & \% \mathrm{~F}=\text { Percent recovery } \\ \mathrm{RCRA}=\text { Resource Conservation and Recovery Act } & \mathrm{TBD}=\text { To be determined } \\ \mu \mathrm{g} / \mathrm{L}=\text { Microgram(s) per liter } & \mathrm{mg} / \mathrm{L}=\text { Milligram(s) per liter }\end{array}$




\subsection{Field Investigation}

This section of the CAIP contains the sampling approach for investigating the Area 3 Landfill Complex CASs. All sampling activities will be conducted in compliance with the Industrial Sites QAPP (DOE/NV, 1996b) and other applicable, approved procedures. Requirements for field and laboratory environmental sampling Quality Assurance and Quality Control are contained in the Industrial Sites QAPP (DOE/NV, 1996b) and Tables 3-1 and 4-1.

Table 4-1

Soil Engineering Analytical Requirements for Geotechnical Studies at the Area 3 Landfill Complex CASs

\begin{tabular}{|l|c|}
\hline \multicolumn{1}{|c|}{ Soil Engineering Analysis } & Method \\
\hline \hline Initial moisture content & ASTM D 2216 \\
\hline Dry bulk density & EM $^{\mathrm{b}}-1110-2-1906$ \\
\hline Calculated porosity & EM-1110-2-1906 \\
\hline Saturated/unsaturated hydraulic conductivity & ASTM D 5084 \\
\hline $\begin{array}{l}\text { Particle-size distribution (preferred method is hydrometer } \\
\text { distribution) }\end{array}$ & ASTM D 422 \\
\hline Water-release (retention) curve & ASTM D 3152 \\
\hline
\end{tabular}

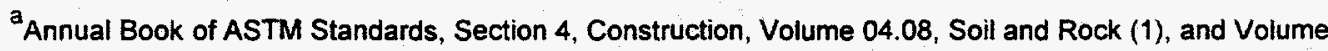
04.09, Soil and Rock (11), 1996.

bunited States Army Corps of Engineers (USACE), Engineer Manual 1110-2-1906, "Laboratory Soils Testing," Appendix II, 1970

ASTM $=$ American Society for Testing and Materials $E M$. = Engineering Manual

\subsection{Sampling Approach}

The sampling approach for the Area 3 Landfill Complex CASs was developed from the DQO process (Appendix A). The sampling plan will consist of drilling multiple boreholes to investigate the soil beneath the landfill cells and drilling three boreholes in undisturbed areas to obtain background data. Continuous field screening and environmental sampling will be conducted in the investigation, and the results will be included in the decision process.

The dry sonic drilling method will be used to advance the holes. The method provides a continuous core from the surface to total depth from which to collect environmental samples and 
examine the cell contents and the soil beneath the cell. The primary reasons the dry sonic drilling method was selected over other investigative methods (i.e., trenching, hollow-stem auger) are:

- Dry sonic drilling significantly reduces the volume of investigative-derived waste (IDW).

- Dry sonic drilling provides a vertical profile and high quality, relatively undisturbed samples.

- Dry sonic drilling provides faster drilling rates and can penetrate most landfill debris so that the soil immediately below the waste can be collected and analyzed.

All landfill cells comprising each CAS will be investigated individually. The planned borehole locations were selected based on geophysical anomalies recorded during the geophysical surveys conducted in 1993 and 1996 (IT, 1997; IT, 1996). These anomalies are assumed to correspond to areas of greater density of debris, which increases the likelihood of drilling through the cell (see Appendix A for other assumptions regarding the location of boreholes). The planned number of boreholes to be drilled and their locations are shown on the individual site maps presented in Section 2.0 and on Plate 1. These borehole locations are approximated and may be adjusted and/or additional locations may be added pending field observations (i.e., surface features).

The planned locations for the background boreholes are presented on Plate 1 and may also be adjusted based on field observations. The background borings were widely spaced to assess the background variability for radiological and inorganic parameters. The borings will be advanced to $7.6 \mathrm{~m}(25 \mathrm{ft})$.

Contingency borings have been proposed for Sites A3-1 and A3-8 because geophysical data indicate anomalies outside the interpreted trench area. These borings will be advanced if field screening results from the initial characterization drilling indicate excessive contamination or if the interpreted cell dimensions are found to be incorrect. Contingency borings are also planned for Site A3-7. These will be advanced to delineate the lateral extent if contamination is detected by field screening. The following sections discuss the field screening and sampling process. 


\subsubsection{Field Screening}

Field screening tests will be performed for all borings from the ground surface to total depth. The field screening methods will consist of headspace testing for VOCs, TPH screening, and radiological screening for alpha and beta/gamma emitters. Soil moisture characteristics will also be continuously measured using a Speedy Moisture Tester ${ }^{\mathrm{Tw}}$; however, this data will only be used for characterization purposes. The field screening data from the first three methods (VOC, TPH, and Radiological) will serve two primary purposes. First, the data will provide continuous environmental measurements of the cell contents (providing sufficient material is available to conduct the tests) and the soil beneath the cell for site characterization. Second, the data will provide a mechanism for guiding the investigation deeper, if necessary. If field screening results exceed the preliminary action levels listed in Section 3.3, then drilling will continue until two consecutive non-detect, or background, results are recorded.

Field screening will be performed at $1.5-\mathrm{m}(5-\mathrm{ft})$ intervals from the surface to approximately $7.6 \mathrm{~m}(25 \mathrm{ft})$. If drilling should need to continue past $7.6 \mathrm{~m}$, field screening will continue in $3.0-\mathrm{m}(10-\mathrm{ft})$ intervals to total depth. A conceptual cross section of the field screening intervals is presented in Figure 3-2.

\subsubsection{Sampling Criteria}

Soil samples for both laboratory analysis and field screening will be collected from all borings using either 5 - or $10-\mathrm{ft}$ long, stainless steel core barrel samplers. The borings designated for background sampling will be sampled at the $3.0-\mathrm{m}(10-\mathrm{ft})$ and $4.6-\mathrm{m}(15-\mathrm{ft})$ depths for radiological and total RCRA metals parameters only. Sample collection for the site characterization holes will be conducted in 1.5-m (5-ft) intervals; the first soil (not landfill contents) sample will be collected in the interval below the landfill bottom. Sample collection will continue to approximately $7.6 \mathrm{~m}(25 \mathrm{ft})$. If field screening results indicate that drilling should continue beyond $7.6 \mathrm{~m}$, then samples will be collected at $3.0-\mathrm{m}(10-\mathrm{ft})$ intervals to total depth. If contamination is detected by field screening, the vertical boundaries or the "bottom of contamination" will be established by two successive, negative field screening measurements, and environmental samples will be collected at these depths for laboratory confirmation. Figure 4-1 presents a generalized decision logic for sampling. A schematic of typical sample collection points is illustrated in Figure 3-2. 


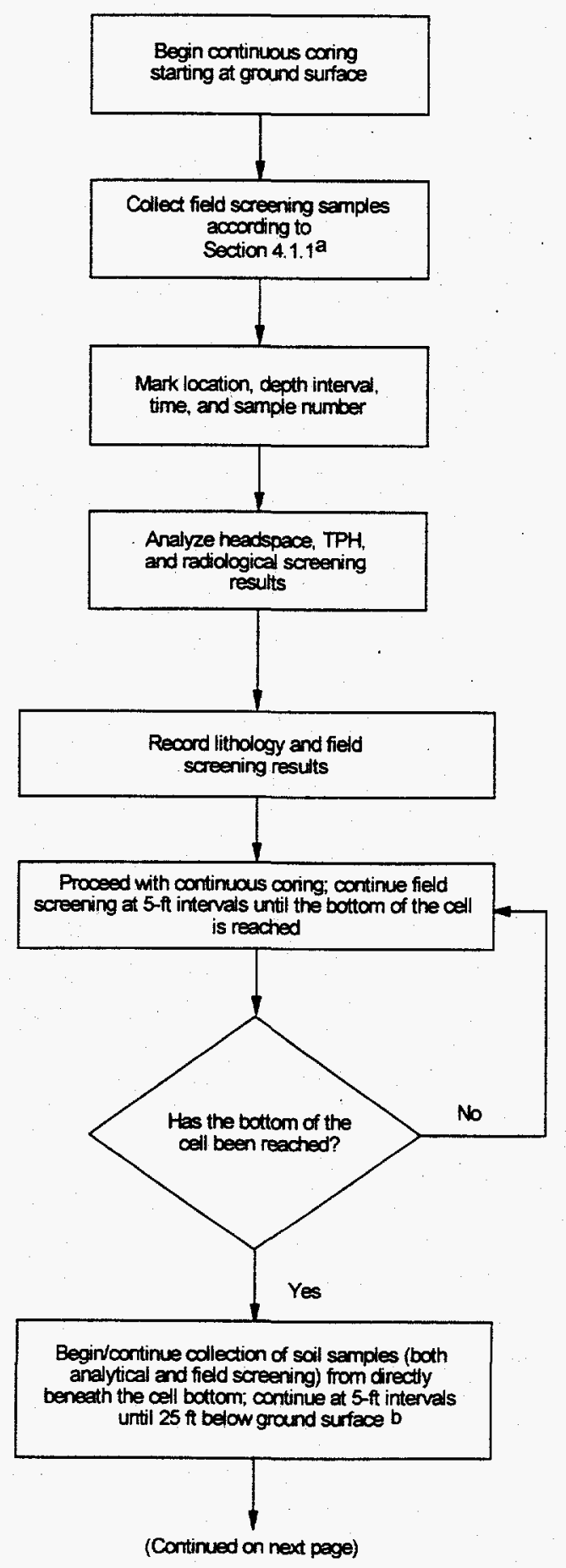

Figure 4-1

Generalized Decision Logic for Corrective Action Site Sampling (Page 1 of 2) 


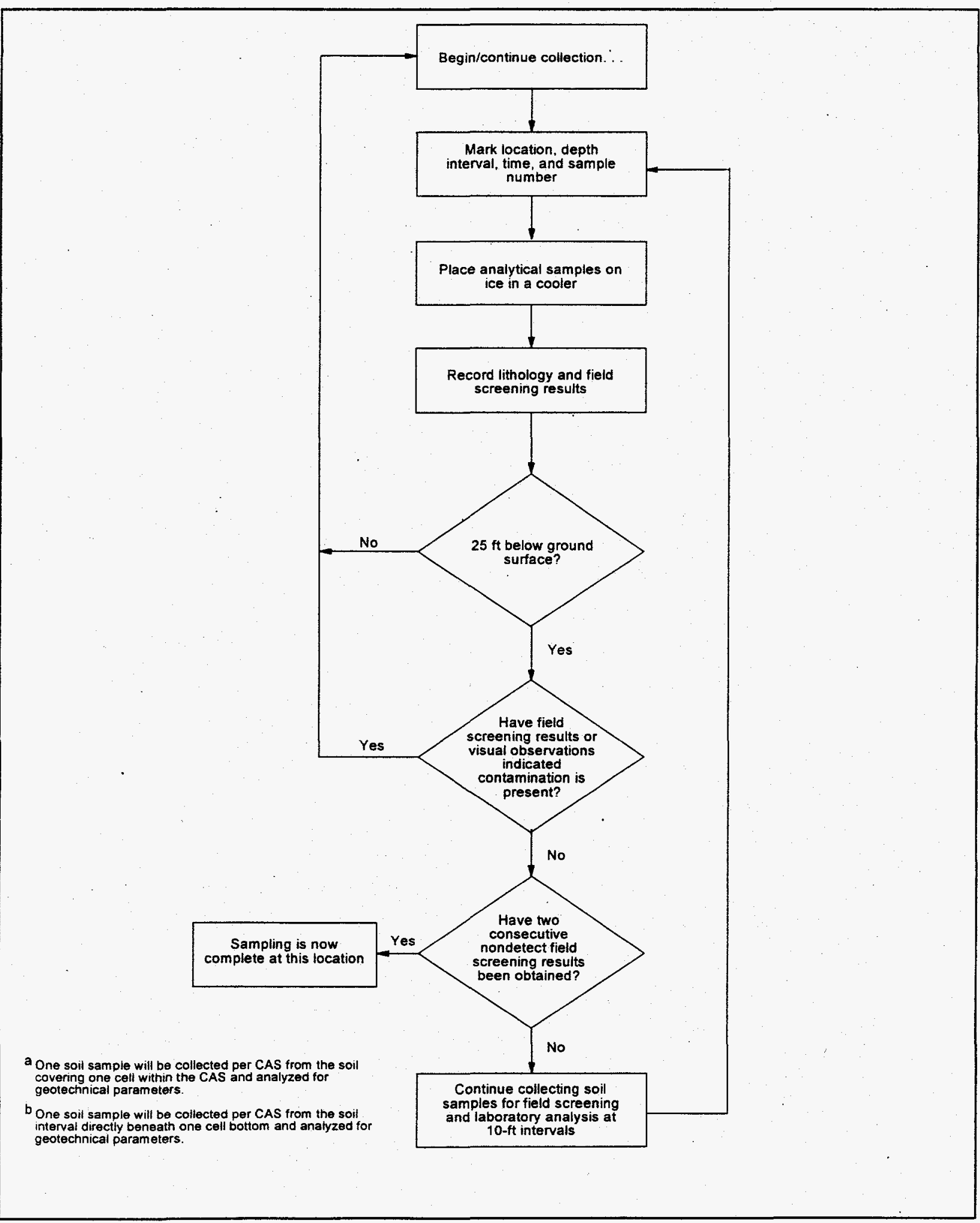

Figure 4-1

Generalized Decision Logic for Corrective Action Site Sampling

(Page 2 of 2) 
Soil samples will be collected from the bottom 0.6-m (2-ft) of each sample interval within the core barrel sampler. Figure 4-2 is a generalized schematic of a core barrel sampler and the sequence to be followed for sample collection. Beginning at the nose of the core barrel, the first two portions will be retained for total VOCs and TPH-gasoline analysis, respectively. The next portion of the core will be retained for VOC and TPH field screening. The forth portion will be retained for total nitroaromatic and nitroamines analysis. The fifth portion will be retained for total SVOCs, PCBs, TPH-diesel, and RCRA metals analysis. The sixth portion will be retained for gamma spectroscopy and isotopic uranium and isotopic plutonium analysis. Once the sample aliquots are collected for gamma spectroscopy and isotopic plutonium analysis, the remaining portion will be archived. The archived sample will be analyzed for isotopic uranium if the presence of uranium above background levels is detected from the gamma spectroscopy analysis. The remaining core will be used (and properly noted) if additional sample volume is needed for samples that are not sensitive to volatilization. The entire core will be field screened for alpha and beta/gamma radiological contamination during sample aliquot collection. Discretionary sampling points may also be selected for laboratory analysis based on a visual examination by the site supervisor/geologist. Selection criteria for discretionary samples could include:

- Moist or discolored zones

- Significant changes in soil grain size

- Increases in odor

Table 3-1 presents the analytical requirements for the Area 3 Landfill Complex samples.

One additional soil sample will be collected from the soil covering the cells (or cap) from one borehole per each CAS (there will be a total of 8 samples collected). To assess the geotechnical characteristics of the existing cap and the soil directly beneath the cell bottoms, this sample, plus the one collected at the cell bottom/natural soil interface from the same borehole, will be analyzed for soil engineering parameters in addition to the chemical parameters. Table 4-1 presents the soil engineering analysis to be used.

All equipment which contacts the soil shall be decontaminated in accordance with contractor's written and approved procedures consistent with the Environmental Restoration Division (ERD) Procedure ERD-05-701, "Sampling Equipment Decontamination," Rev. 0 (DOE/NV, 1994d), or as appropriate for special equipment being decontaminated (i.e., steam-cleaning core barrels). Clean core barrels shall be used for each sampling event. This will minimize the potential for 
Enlargement of core-barrel sampler.

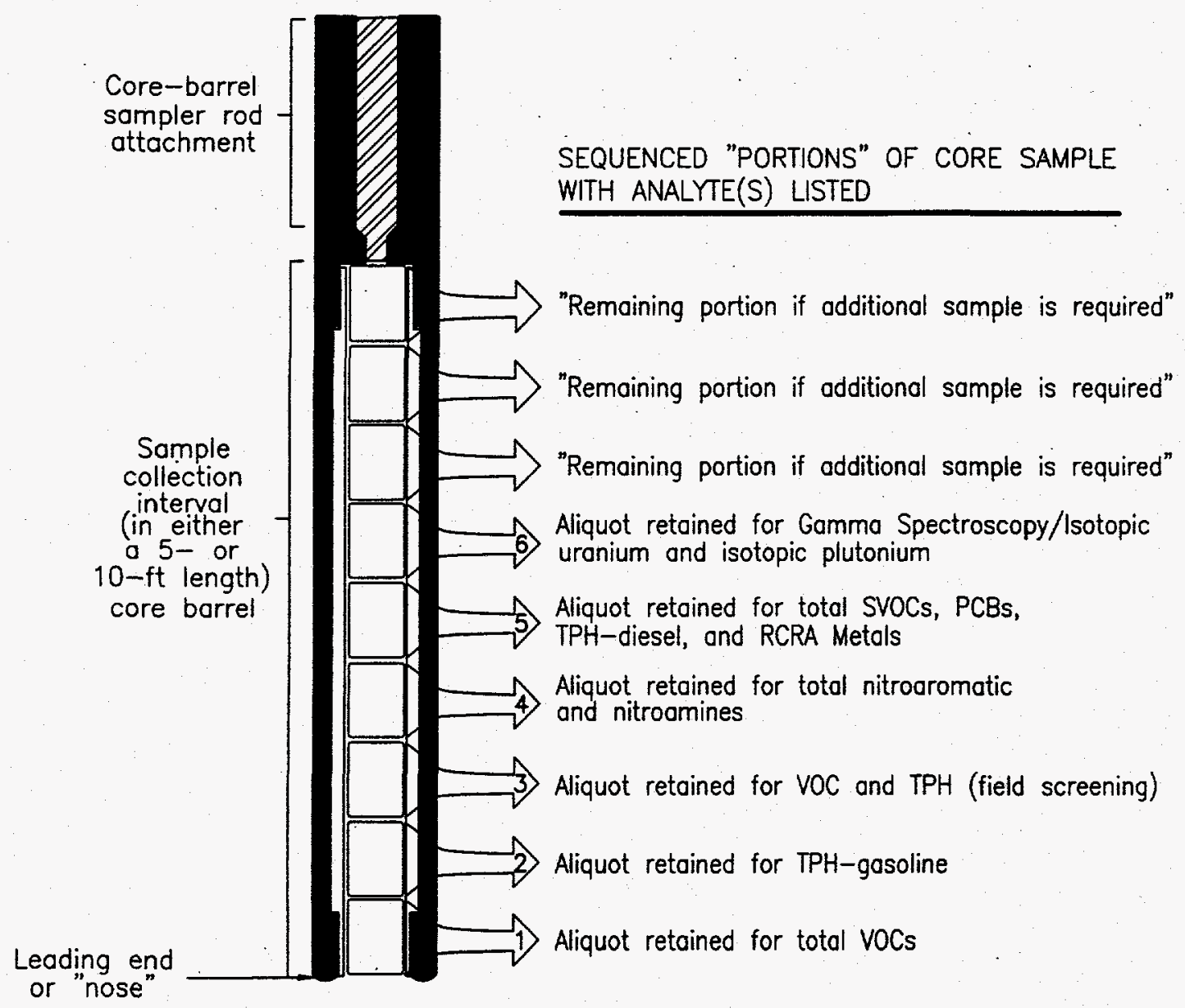

NOT TO SCALE

\section{NOTE}

1. This is an unlined core barrel.

2. Interval lengths for each aliquot ("portion")

will vary based on sample volume requirements. 
cross-contamination between sample locations. All samples collected for laboratory analysis will be grab samples of fresh media (rather than reusing the sample media used for screening).

Records will be kept of the soil description, field screening measurements, and all other relevant data. All pertinent and required sampling information (i.e., date, time, sample interval) shall be documented in accordance with the Industrial Sites QAPP (DOE/NV, 1996b). Approved contractor Chain of Custody procedures will be followed to assure the defensibility of the data.

\subsubsection{Stop Points for Notification}

The following represent specific stop points that were determined during the DQO process to provide guidance on unexpected situations that may arise during the field investigation:

- If field screening results indicate that contamination is more extensive than predicted (i.e., drilling advances to the saturated zone), the field investigation will stop, NDEP will be notified, and the site rescoped.

- If free liquids are encountered during the drilling operation, drilling will stop and NDEP will be notified for decision concurrence.

- If radiation is encountered above field screening action levels (i.e., two times background), drilling will stop; the NDEP will be notified; and the need to initiate a Radiological Work Permit will be assessed.

- If operations need to stop because of unexpected site conditions, NDEP will be notified.

- If drilling encounters bit refusal that precludes successful investigation of a cell, NDEP will be notified for decision concurrence.

- If conditions warrant changing the drilling method, NDEP will be notified and the investigation rescoped. 


\subsection{Waste Management}

There is no process knowledge that indicates hazardous (i.e., RCRA-regulated) or radioactive wastes were placed in the landfill. There is no record that indicates that chemicals or solvents were discarded in the landfill. Therefore, any potential hazardous wastes placed in the landfill would be characteristic, rather than listed, wastes. The soil will be field-screened, sampled, and analyzed to verify that this process knowledge is correct. Waste generated through sampling will be traceable to its source and to individual samples. Administrative controls (e.g., decontamination procedures, drilling method, and characterization strategies) will minimize waste generated during site characterization activities. Decontamination activities will be performed in accordance with approved procedures as specified in the field sampling instructions (to be written prior to commencement of field work) and will be designated according to the contaminants of concern present at the site.

If laboratory results indicate that the waste exhibits a hazardous characteristic, the waste will be managed as hazardous waste in accordance with RCRA (DOE/NV, 1994b). As soon as it is known that the waste is hazardous (i.e., through field screening or laboratory analyses), the waste will be managed as hazardous, with the 90 -day accumulation time limit starting when the waste is identified as hazardous. As soon as it is known that the waste is radioactive or mixed (i.e., through field screening or laboratory analyses), the waste will be managed in accordance with the Nevada Test Site Waste Acceptance Criteria (NTSWAC) (DOE/NV, 1996e) and the "Mutual Consent Agreement Between the State of Nevada and the U.S. Department of Energy for the Storage of Low-Level Land Disposal Restricted Mixed Waste" (NDEP, 1995), respectively. All waste types, if present, will be managed according to U.S. Department of Transportation (DOT) regulations as well.

\subsection{Waste Minimization}

The investigation activities have been designed to minimize the amount of IDW generated. Through the use of dry sonic drilling, the volume of soil cutting will be significantly minimized. Waste segregation will be applied to identified waste streams.

\subsection{Potential Waste Streams}

There are no records that indicate that chemicals or solvents were discarded in the landfills. The potential wastes found in the landfill are likely to be characteristic, rather than listed, wastes. 
The determination of whether the waste is characteristic or listed is based on the Code of Federal Regulations (CFR) Title 40 Part 261, "Identification and Listing of Hazardous Wastes" (CFR, 1996a). Process knowledge also indicates that there is very little reason to believe that hazardous (i.e., RCRA-regulated) or radioactive wastes were placed in the landfills. Based on this process knowledge, hazardous wastes, radioactive wastes, or mixed wastes are not anticipated to be generated. In the unlikely event that hazardous or radioactive waste is encountered, drilling will be stopped and NDEP will be notified. The reagents used in the TPH field screening methods will produce small quantities of hazardous wastes, and this small waste stream will be segregated and managed as follows:

- The waste shall be compatible with the container.

- The container shall be in good condition and free from corrosion and dents that impair the integrity of the container.

- At a minimum, the container shall be labeled with the following information:

- The words "Hazardous' Waste"

- A unique waste stream identification number

- All applicable EPA and state waste numbers and/or codes

- A description of the contents

- Contact name

Wastes generated during the investigation activities may include, but are not limited to, the following:

- Decontamination rinsate

- Contaminated disposable sampling equipment (e.g., plastic, paper, aluminum foil, and sample containers)

- Personal protective equipment

- Contaminated soil

- Soil contaminated by colorimetric TPH testing

- Contaminated core material 


\subsection{Waste Management}

Proper waste management consists of making a determination of waste status (i.e., RCRAhazardous) and management based on the waste determination. A waste determination will be made on the waste as presented in Section 5.3.1. The waste will then be managed according to the determination as discussed in Section 5.3.2.

\subsubsection{Waste Determination}

Solid materials other than soil wastes are waste only by virtue of contact with contaminated media. The same is true of decontamination rinsate. A waste determination on the soil cuttings will be made per boring according to sample results for that boring. Therefore, sampling and analysis of the IDW (including soil from the borings), separate from site characterization analyses, will not be required. The data generated as a result of site characterization will be used to assign the appropriate waste type (i.e., unregulated TPH, hazardous, low-level waste [LLW], or mixed) to the IDW. The action levels for IDW contaminants are presented in Table 5-1.

Table 5-1

Action Levels for IDW Contaminants

\begin{tabular}{||l|l|l|l||}
\hline \multicolumn{1}{|c|}{ Parameter } & \multicolumn{1}{|c|}{ Action Level } & \multicolumn{1}{c|}{ Source } & \multicolumn{1}{c|}{ Comments } \\
\hline \hline TPH $^{\mathrm{a}}$ & $100 \mathrm{ppm}^{\mathrm{b}}$ & NAC $^{\mathrm{c}} 459.9973$ & $\begin{array}{l}\text { Regulated by the } \\
\text { NDEP }^{\mathrm{d}}\end{array}$ \\
\hline $\begin{array}{l}\text { Total VOCs } \\
\text { pesticides, and } \text { RCRA }^{\mathrm{g}} \\
\text { metals }\end{array}$ & See note below & $40 \mathrm{CFR}^{\mathrm{h}} 261^{\mathrm{i}}$ & - \\
\hline Total PCBs & $50 \mathrm{ppm}$ & $\begin{array}{l}40 \text { CFR } 761.1(\mathrm{~b})^{\mathrm{k}} \\
\text { NAC } 444.940 \text { to } \\
444.9555\end{array}$ & $\begin{array}{l}\text { NDEP requires } \\
\text { manifesting as } \\
\text { hazardous waste for } \\
\text { shipping and disposal } \\
\text { purposes. }\end{array}$ \\
\hline Radiological & Isotope specific & NTS POC' & - \\
\hline
\end{tabular}

a Total petroleum hydrocarbons

Part(s) per million

Nevada Administrative Code (NAC)

Nevada Division of Environmental Protection

eVolatile organic compound(s)

'Semivolatile organic compound(s)

${ }^{9}$ Resource Conservation and Recovery Act h Code of Federal Regulations

CFR, 1996a

'Polychlorinated biphenyl(s)

kCFR, 1996a

Nevada Test Site Performance Objective for Certification of Radioactive Hazardous Waste (BN, 1995)

Note: Total VOCs, SVOCs, pesticides, and RCRA metal concentrations of the samples will be determined through laboratory analysis. The laboratory-derived concentrations for soil samples (milligram/kilogram [ $\mathrm{mg} / \mathrm{kg}]$ ) will be divided by a factor of 20 and compared to the toxicity characteristic (TC) limit (milligram/liter [mg/L]) for hazardous parameters. If the total value divided by 20 is greater than the TC limit, IDW associated with these samples will be considered hazardous waste. 


\subsubsection{Waste Management}

By adhering to administrative controls, sampling personnel will ensure that no additional contaminants are added to the waste. For administrative purposes, the waste will be managed as three waste streams (at least): soil, contaminated solid trash, and liquid wastes (such as decontamination rinsate). Each waste stream will be segregated, and additional segregation may occur within each waste stream. For example, soil cuttings will be segregated per boring; the soil waste and decontamination rinsate will be segregated; and liquid low-level or mixed wastes, if present, will be absorbed or solidified prior to disposal or storage.

Investigation-derived waste streams will be segregated and placed into waste containers such as DOT-compliant drums (i.e., borehole soil, contaminated personal protective equipment, and decontamination rinsates). The contents of each container will be recorded, and each container will be appropriately marked and labeled in accordance with RCRA and DOE requirements (40 CFR 262, 1997; 49 CFR 172, 1997). Wastes will be managed on site within the defined site boundaries until analytical results are received to determine the disposition of the waste. Access to wastes temporarily staged at the project site will be controlled through placing the waste within an access-controlled area. All waste containers (e.g., drums) will be covered and/or locked and appropriately labeled. Waste containers will be periodically inspected while awaiting laboratory results to ensure that the waste containers are not leaking or damaged.

If mixed waste is produced, the appropriate data on the status of the waste must also be obtained or developed in accordance with the Transuranic Waste Pad waste storage criteria (DOE Order 460.1A, 1996; DOE Order 5820.2A, 1995; DOE/NV, 1996e; NTS SOP 5409, 1993). The number of samples necessary to satisfy the various mixed waste management requirements (e.g., RCRA [DOE/NV, 1994b], NVO-325 [DOE/NV, 1992b]) will depend on the volume of IDW produced and/or the variability in the analytical values for the IDW produced. Investigation-derived waste will be disposed of appropriately depending on the type of contamination identified in the samples. 


\subsection{Time Frame and Records Availability}

\subsection{Time Frame}

Following approval of this CAIP, the following is a tentative schedule of activities (in working days):

- Day 0: Preparation for field work will begin.

- Day 45: The field work, including field screening and sampling, will begin.

- Day 80: The field work will be completed and samples shipped to the laboratory for analysis.

- Day 140: The quality-assured laboratory analytical sample data will be available for NDEP review.

- Day 290: The Corrective Action Decision Document (CADD) will be submitted to NDEP.

The following information will be reported in the CADD:

- Introduction, including purpose, scope, an FFACO cross-walk, and a discussion about the need for further action

- The results of the corrective action investigation

- A corrective measures study, including initial screening of alternatives, evaluation of alternatives, and comparison of alternatives

- The recommended alternative

\subsection{Records Availability}

Historic information and documents referenced in this plan are retained in IT Corporation project files in Las Vegas, Nevada, and can be obtained through written request to the DOE/NV Project Manager. 


\subsection{References}

APHA, see American Public Health Association.

American Public Health Association. 1992. Gross Alpha and Gross Beta Radioactivity, Standard Methods for the Examination of Water and Waste Water, 18th Edition.

Washington, DC.

ASTM, see American Society for Testing and Materials.

American Society for Testing and Materials. 1996. Annual Book of ASTM Standards, 04.08 and 04.09. Philadelphia, PA.

Bechtel Nevada. 1995. Nevada Test Site Performance Objective for Certification of Nonradioactive Hazardous Waste. Las Vegas, NV.

BN, see Bechtel Nevada.

CFR, see Code of Federal Regulations.

Code of Federal Regulations. 1996a. 40 CFR Part 261, "Identification and List of Hazardous Waste." Washington, DC: U.S. Government Printing Office.

Code of Federal Regulations. 1996b. 40 CFR Part 761.1(b), "Polychlorinated Biphenyls (PCBs) Manufacturing, Processing, Distribution in Commerce, and Use Prohibitions." Washington, DC: U.S. Government Printing Office.

Code of Federal Regulations. 1996c. 40 CFR.Part 262, "Protection of Human Subjects." Washington, DC: U.S. Government Printing Office.

Code of Federal Regulations. 1997a. 40 CFR Part 262, "Standards Applicable to Generators of Hazardous Waste." Washington, DC: U.S. Government Printing Office.

Code of Federal Regulations. 1997b. 49 CFR Part 172, "Hazardous Materials Table, Special Provisions, Hazardous Materials Communications, Emergency Response Information, and Training Requirements." Washington, DC: U.S. Government Printing Office.

DOE, see U.S. Department of Energy.

DOE/NV, see U.S. Department of Energy, Nevada Operations Office.

EPA, see U.S. Environmental Protection Agency. 
FFACO, see Federal Facility Agreement and Consent Order.

Federal Facility Agreement and Consent Order. 1996. Agreed to by the State of Nevada, the U.S. Department of Energy, and the U.S. Department of Defense.

IT, see IT Corporation.

IT Corporation. 1996. Geophysical Survey Field Data for Area 3 Landfill Cells A3-3, A3-5, A3-6, A3-7, and A3-8, Tonopah Test Range, November.

IT Corporation. 1997. Initial Surface Geophysical Survey Report for the Tonopah Test Range Environmental Restoration Sites, ITLV10972--93. Las Vegas, NV.

Karas, P. 1993a. Transcripts of TTR ER interview between Gary West (Former TTR Range Operations Supervisor), R. Dubiskas (IT), and P. Karas (CDM Federal), 8 June. Las Vegas, NV.

Karas, P. 1993b. Transcripts of TTR ER interviews between Robert Statler (Former TTR Range Manager), R. Dubiskas (IT), D. Howard (RSN), and P. Karas (CDM Federal), 28 June. Las Vegas, NV.

Karas, P. 1993c. Transcripts of TTR ER interviews between Robert Statler (Former TTR Range Manager), J. Quas (REECo), S. Galvin (REECo), R. Dubiskas (IT), D. Howard (RSN), and P. Karas (CDM Federal), 6 July. Las Vegas, NV.

LAS Laboratories, Inc. 1993. "Sample Preparation, Nuclide Separation and Analysis," Standard Operating Procedure LAL-91-SOP-0108. Las Vegas, NV.

LAS Laboratories, Inc. 1996a. "Sample Preparations and Analysis for Gamma Activity in Aqueous Samples," Standard Operating Procedure LAL-91-SOP-0063. Las Vegas, NV.

LAS Laboratories, Inc. 1996b. "Sample Preparation and Analysis for Gamma Activity in Solids," Standard Operating Procedure LAL-91-SOP-0064. Las Vegas, NV.

McArthur, R. D., and F.L. Miller, Jr. 1989. Offsite Radiation Exposure Review Project (ORERP), Phase II Soils Programs, DOE/NV/10384-23. Las Vegas, NV: Desert Research Institute.

NAS, see National Academy of Science.

NAC, see Nevada Administrative Code.

National Academy of Science. 1962. Nuclear Science Series. 
National Academy of Science. 1963. Nuclear Science Series.

Nevada Administrative Code. 1990. NAC444.940-444.9555. Carson City, NV.

Nevada Administrative Code. 1996. NAC459.9973. Carson City, NV.

NDEP, see Nevada Division of Environmental Protection.

Nevada Division of Environmental Protection. 1995. "Mutual Consent Agreement Between the State of Nevada and the Department of Energy for the Storage of Low-Level Land Disposal Restricted Mixed Waste." Transmittal from P. Liebendorfer (NDEP) to D. Elle (DOE/NV), 7 June. Carson City, NV.

Quas, J. 1993. Notes from meeting with Randy Dubiskas (IT) and Ed Mignardot for IT Corporation, 27 July.

SNL, see Sandia National Laboratories.

Sandia National Laboratories. 1992. Tonopah Test Range Facility Reports, 1709TTR. Las Vegas, NV.

Smucker, S. J., U.S. Environmental Protection Agency. 1996. Transmittal from S.I Smucker to PRG Table Mailing List. Subject: Region 9 Preliminary Remediation Goals (PRGs), 1 August. San Francisco, CA.

USACE, see U.S. Army Corps of Engineers.

United States Army Corps of Engineers. 1970. "Laboratory Soils Testing." Engineering Manual 1110-2-1906, Appendix II. Washington, DC.

U.S. Department of Energy. 1988. Order 8520.2A, Radioactive Waste Management, Washington, DC.

U.S. Department of Energy. 1992a. Environmental Measurements Laboratory Procedures Manual, HASL-300, 27th Edition, Volume 1. New York, NY.

U.S. Department of Energy. 1992b. Nevada Test Site Defense Waste Acceptance Criteria, Certification, and Transfer Requirements, NVO-325, Rev. 1. Las Vegas, NV:

U.S. Department of Energy, Nevada Operations Office.

U.S. Department of Energy. 1993. "Management of Hazardous Materials and Hazardous Wastes," NTS SOP-5409. 
U.S. Department of Energy, 1996. Order 460.1A, Packaging and Transportation Safety. Washington, DC.

U.S. Department of Energy, Nevada Operations Office. 1994a. Project Management Plan, Rev. 0. Las Vegas, NV.

U.S. Department of Energy, Nevada Operations Office. 1994b. Resource Conservation and Recovery Act Industrial Sites Quality Assurance Project Plan, Nevada Test Site, Nevada, Rev. 0. Las Vegas, NV.

U.S. Department of Energy, Nevada Operations Office. 1994c. Environmental Restoration Project Health and Safety Plan, Rev. 1. Las Vegas, NV.

U.S. Department of Energy, Nevada Operations Office. 1994d. "Sampling Equipment Decontamination," ERD-05-701, Rev. 0. Las Vegas, NV.

U.S. Department of Energy, Nevada Operations Office. 1996a. Corrective Action Unit Work Plan, Tonopah Test Range, Nevada. Las Vegas, NV.

U.S. Department of Energy, Nevada Operations Office. 1996b. Resource Conservation and Recovery Act Industrial Sites Quality Assurance Project Plan, Nevada Test Site, Nevada, DOE/NV--372. Las Vegas, NV.

U.S. Department of Energy, Nevada Operations Office. 1996c. Corrective Action Investigation Plan: Roller Coaster Lagoons and North Disposal Trench, Tonopah Test Range, DOE/NV-425. Las Vegas, NV.

U.S. Department of Energy, Nevada Operations Office. 1996d. Streamlined Approach for Environmental Restoration Plan, CAU No. 400: Bomblet Pit and Five Points Landfill, Tonopah Test Range, DOE/NV--424. Las Vegas, NV.

U.S. Department of Energy, Nevada Operations Office. 1996e. Nevada Test Site Waste Acceptance Criteria, NTSWAC, Rev. 0. Las Vegas, NV.

U.S. Environmental Protection Agency. 1992. Test Methods for Evaluating Solid Waste, Physical/Chemical Methods, SW-846, 3rd Edition, PB89-148076. Washington, DC.

U.S. Environmental Protection Agency. 1994. Guidance for the Data Quality Objectives Process, EPA QA/G-4. Washington, DC. 
CAIP CAU No. 424

Section: Appendix A

Revision: 0

Date: 04/25/97

Page $i$ of $i i i$

\section{Appendix A}

(Data Quality Objective Worksheet) 


\section{Table of Contents}

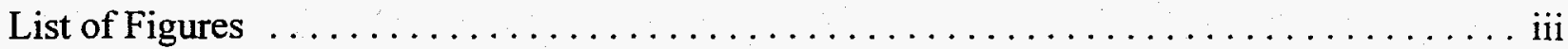

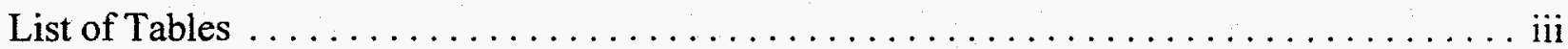

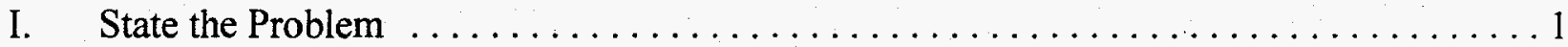

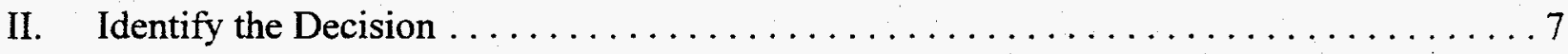

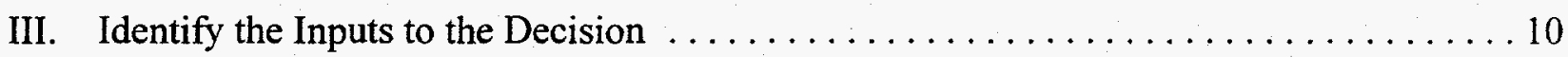

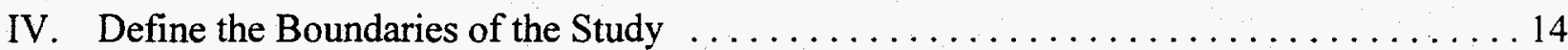

V. Develop a Decision Rule - Define a Logical Basis for Choosing Among Alternative Actions ..................................... 16

VI. Specify Acceptable Limits on Decision Errors - Specify Decision Error Limits Based on the Consideration of the Consequences of Making an Incorrect Decision

VII. Optimize the Design - Outline a Sampling Design, Specifying the Operational Details of the Sampling Plan which Falls within the Project's Constraints

VIII. References ............................................... 33

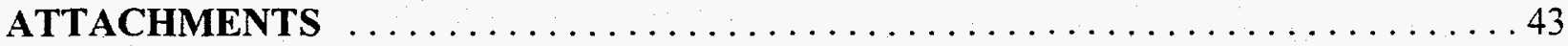

Attachment A - Area 3 Landfill, Historical Aerial Photos $\ldots \ldots \ldots \ldots \ldots \ldots \ldots . \ldots . \ldots 4$

Attachment B - Map of Landfill Cells . ............................ 46

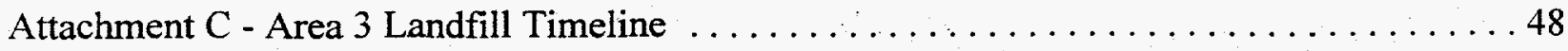

Attachment D - Chemical, Biological, and Radiological Hazards at Building

Structures Inspected at Sandia National Laboratories, Tonopah Test Range . . . . . . . . 50

Attachment E - Tonopah Test Range, Area 3, Building Year Built Report $\ldots \ldots \ldots \ldots \ldots 60$

Attachment F - FY 97 Industrial Sites Schedule CAU 424 - Area 3 Landfill ............. 64

Attachment $G$ - Drilling/Investigation Options for Area 3 Landfill Complex $\ldots \ldots \ldots \ldots 66$ 


\section{List of Figures}

Number

Title

Page

Figure 1 Proposed Boring Locations, Area 3 Landfill Cells A3-1, A3-1a, and A3-2 . . . . 35

Figure 2 Proposed Boring Locations, Area 3 Landfill Cell A3-3 . . . . . . . . . 36

Figure 3 Proposed Boring Locations, Area 3 Landfill Cell A3-4 . . . . . . . . . 37

Figure 4 Proposed Boring Locations, Area 3 Landfill Cell A3-5 . . . . . . . . . . 38

Figure 5 Proposed Boring Locations, Area 3 Landfill Cell A3-6 . . . . . . . . . . . 39

Figure 6 Proposed Boring Locations, Area 3 Landfill Cell A3-7 . . . . . . . . . . 40

Figure 7 Proposed Boring Locations, Area 3 Landfill Cell A3-8 . . . . . . . . . 41

Figure 8 Landfill Cell Grid Map, Proposed Background Boring Locations . . . . . . . . . 42

\section{List of Tables}

Title

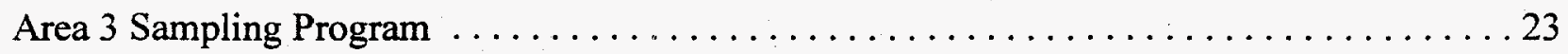



AREA 3 LANDFILL CHARACTERIZATION EFFORT

Notes from the DQO Scoping Meetings Conducted on November 20 and 26 and December 11, 1996.

These notes are based on the "Strawman" outline provided for the meetings by IT and on the discussions held by the core decision team and the scoping team members. The notes follow the outline of the DQO guidance (EPA, 1994). The steps systematically build on the data acquired during background research for the Corrective Action Investigation Plan (CAIP). Copies of the background data are in IT project files. To view the operational details of the sampling plan, see Step VII of this worksheet.

\section{State the Problem}

A. Summarize the contamination problem - combine the relevant background information into a concise description of the problem to be resolved.

Problem to be Resolved

Determine whether solid waste in trenches has contaminated or has the potential to contaminate underlying soil or groundwater to the extent that it is a hazard to potential receptors. The extent to which these materials may have impacted surrounding and underlying soil and/or groundwater is currently not known, but it must be determined in order to close the site under Nevada Division of Environmental Protection (NDEP) and DOE requirements per the Federal Facility Agreement and Consent Order (FFACO).

B. Identify the members of the Scoping Team:

1. Scoping Team:

DOE/NV

Kevin Cabble

Lori Arent

Gloyd Green

IT Corp.

Kenneth Beach

Randy Dubiskas

Brad Schier

Mark Unruh

Cheryl Rodriguez

Syl Hersh

Jeanne Wightman
NDEP

Paul Liebendorfer

Karen Beckley

Bechtel

Dave Madsen

Steve Nacht 
2. Core Decision Team:

Kevin Cabble

Paul Liebendorfer

Karen Beckley

Randy Dubiskas

Cheryl Rodriquez

Mark Unruh

Dave Madsen

3. Primary Decision Makers:

Kevin Cabble

Paul Liebendorfer

Karen Beckley

C. Develop/Refine the Conceptual Model.

1. List sources of historic data associated with previous data collection activities.

a. Initial Surface Geophysical Survey Report for the Tonopah Test Range Environmental Restoration Sites (IT, 1997)

b. Geophysical survey data generated from IT Corporation (IT) field activities conducted at landfill cells A3-3, A3-5, A3-6, and A3-8, Tonopah Test Range (TTR), November 1996 (IT, 1996)

c. Vintage aerial photographs of the Tonopah Test Range in ITLV (IT Corporation, Las Vegas) files (see Attachment A)

d. Process knowledge in the form of personnel interviews conducted with former TTR workers (Karas, 1993 (a) and (b); Phelan, 1988; Quas, 1993; West, 1987)

e. Inspection of Building Structures at Sandia National Laboratories, Tonopah Test Range, August, 1994 (ITLV 3232TTR) (IT, 1994)

f. Tonopah Test Range Facility Reports (ITLV 1709 TTR) (SNL, 1992)

g. 1993 Site Environmental Report, Tonopah Test Range, Tonopah, Nevada (Culp et al., 1994)

h. Corrective Action Unit Work Plan, Tonopah Test Range, Rev. 0 (DOE/NV--443) (DOE/NV, 1996a) 
i. Environmental Assessment, Tonopah Test Range, Tonopah, Nevada (ERDA, 1975)

j. Federal Facility Preliminary Assessment Review. Tonopah Test Range, Nye County, Nevada (Ecology and Environment, Inc., 1989)

k. Corrective Action Investigation Plan: Roller Coaster Lagoons and North Disposal Trench, Tonopah Test Range, Revision 1 (DOE/NV, 1996b)

\section{List known or suspected sources of contamination.}

The Area 3 Landfill CAU is comprised of eight separate CASs with varying waste disposal times. Attachment B, the site map, shows the eight CASs. The attached timeline (Attachment $C$ ) shows the approximate time that wastes were disposed of in the trenches. The timeline was prepared using observations from the aerial photographs listed in Attachment A.

The eight CASs are treated in the DQO exercise as separate study areas. Evidence for the contents of the waste trenches includes:

a. Construction debris from site operations is suspected on the basis of interviews and aerial photographs.

b. Descriptions of processes/activities in buildings serving as potential waste sources (from the site inspection report and as-built drawings). Attachment D describes the hazardous materials observed in each building in 1994. There.is some potential for these buildings to have contributed hazardous materials to the Area 3 trenches. However, improved waste management procedures in the late 80 s and early 90s limited the potential for hazardous materials in the later trenches.

The "Building Year Built Report" (Attachment E) lists the date of construction for buildings in Area 3. Assuming that operations in 1994 were similar to those in 1980 , a partial list of buildings with the potential to contribute hazardous materials to the Area 3 trenches includes:

Paint, Carpenter, Plumbing Shop

Electrical Maintenance

Welding, Sheet Metal Shop

Tire Shop

Photo Shop

Equipment Maint. Machine Shop

Radio Shop
Heavy Duty Repair Shop

Automotive Maintenance

Weapons Cleaning

Weapons Maintenance

Generator Shop

Battery Storage 
Note: The mention of laboratories on the list (Attachment E) refers to electronic laboratories, not biological or chemical.

Due to the presence of sewer/septic system lines and underground discharge points associated with most of the buildings in question, it is assumed that wastes were segregated into solid vs. liquid waste types. The solid waste was disposed of in the landfill cells while the liquids were disposed of in the sewer/septic systems and underground discharge points (see "Uncertainties" below).

c. Office and sanitary trash - process knowledge (Quas, 1993)

d. Low-level radioactive waste in the form of depleted uranium fragments (Karas, 1993a)

e. Uncertainties:

The list of potential contaminants is based on the assumption that 1994 processes were similar to earlier hazardous materials used at the site. Some of the inherent uncertainties include:

(1) Quantities - Solid waste quantities can be roughly estimated by the volume of the trenches, but there is no way of estimating what percentage is hazardous.

(2) Physical State - Most of the hazardous materials listed in the building descriptions are in liquid form. It is not likely that large amounts of liquid wastes were disposed of in the trenches, it would have been more convenient for workers to dispose of liquids in the sewer system.

\section{List types of contaminants and affected media.}

All the landfills are currently closed. Aerial photographs indicated they were closed by covering with clean fill. Therefore, the affected media at the site will be subsurface soils around and below the landfills. It is assumed that the wastes disposed of in the landfills are nonhazardous solid wastes similar to wastes in municipal or Department of Defense landfills. There is no evidence verifying disposal of hazardous materials. Potential types of contaminants that could be present are based on the sources listed in the previous section (C.2). Because the landfills operated at different times, but all had similar sources, all the landfills have the potential for the contaminants in the following list. 
(See Attachment $\mathrm{D}$ for building inspection results)
a. VOCs
b. RCRA metals - lead, etc.
c. SVOCs
d. Radionuclides - depleted uranium (DU)
e. PCBs
f. TPH
g. Pesticides - rat poison (Karas, 1993b)
h. Corrosives (batteries) - (Karas, 1993b) - likely neutralized

\section{List known or potential routes of migration.}

a. Primary Model

(1) Infiltration and concentration of potential contaminants into the soil directly below the landfill

(2) Minor lateral migration (due to anisotropy) of potential contaminants in the form of leachate into the soil

(3) Infiltration limited to less than 25 feet of vertical and 10 feet of lateral migration

b. Alternate Model

(1) Infiltration, as described in C.4.a.(1) and C.4.a.(2) above, greater than 25 feet of vertical migration

(2) If migration is greater than approximately 300 feet, potentially contaminated groundwater

\section{List known human and environmental receptors.}

a. On-site personnel - potential for inadvertent intrusion

b. Plants and animals - minimum potential/exposure

c. Future land use impacts

d. Groundwater impacts - very low potential, liquids disposed in building-specific drains/septic systems. 


\section{Define the exposure pathway(s).}

1. Define the exposure pathway(s).

a. Ingestion or inhalation of soil, after excavation, is considered to be the most likely exposure pathway.

b. Exposure potential related to groundwater contamination is considered possible but highly unlikely because the groundwater is estimated to be deeper than $91 \mathrm{~m}$ $(300 \mathrm{ft})$ below the site.

\section{Define the current and future land use.}

a. Current - unimproved surface. Surrounding land use varies according to the particular landfill site. The following summarizes the current status of each site:

A3-1 = Situated in a remote area removed from buildings and activity

A3-2 = Located in a semiremote area near a former, frequently traveled road; recently the road was barricaded for no access. Up until at least 1988 , the site was used as a surface storage area.

A3-3 = Located (mostly) inside the current Area 3 compound; day-to-day operations are conducted in the immediate vicinity.

A3-4 = Located in a semiremote area, near and below (in part), a heavily trafficked, improved road. Recent surface storage use appears to be encroaching site.

A3-5 = Located in a fairly remote corner of the Area 10 compound. Heavily trafficked, improved road in the vicinity.

A3-6 = Located between the Area 3 and Area 10 compounds. Area recently used as a surface storage area.

A3-7 = Located in an area removed from buildings and activity. Heavily trafficked, improved road in the vicinity.

A3-8 = Located in an area currently being used to store boxcars, spools of wire, generators, and tires. Note: Landfill Cell A3-8 was identified from an historical aerial photo. Based on the photo, the cell is located beneath four rows of boxcars, 12 boxcars total. A geophysical survey consisting of both electromagnetic and ground penetrating radar (GPR) surveys was performed around and between the boxcars. Results indicated metallic anomalies (potential landfill cell/s) located southeast and north of the boxcars. There was metallic interference from the boxcars. GPR, however, confirmed that anomalies located within the boxcar area are limited to the southeast corner. After further inspection of the historical aerial photo, the shape of what was believed to be the landfill cell appears to be shaped for some other purpose (i.e., a truck loading ramp). 
b. Future - likely to be similar to current use; however, A3-2, A3-3, and A3-6 are in the likely pathways for possible future expansion of the Area 3 Compound. The A3-5 site may become incorporated into possible airport expansion.

3. Define applicable or relevant and appropriate requirements (ARARs) or preliminary remediation goals (PRGs). The primary ARARS for the landfill are Chapter 444 Solid Waste Disposal (NAC 444.7481) and 40 CFR Subtitle D.

Other action levels to be considered in order to designate screening levels to establish stop points for the characterization activities include:

- EPA Region 91996 PRGs for hazardous, metallic, and PCB constituents

- NDEP action level for TPH (100 ppm)

- Background radiological levels or levels listed in the Offsite Radiation Exposure Review Project (ORERP), Phase II Soils Programs report (DOE/NV/10384-23) (McArthur and Miller, 1989).

\section{Develop the exposure scenario.}

a. Excavation of contaminated material

b. Migration of potential contaminants into groundwater is unlikely to occur due to the extensive depth to groundwater estimated at $103 \mathrm{~m}$ to $120 \mathrm{~m}$ (338 $\mathrm{ft}$ to $394 \mathrm{ft}$ ) in this area.

\section{E. Specify the available resources.}

1. Specify monetary budget for the field investigation.

The amount will be determined based on budgetary constraints; however, allocations should be sufficient to address each site.

2. Define relevant time constraints.

See Attachment F.

II. Identify the Decision

A. Select the appropriate decision for the current phase of the site assessment process.

It is assumed that the wastes disposed of in the landfills are nonhazardous solid wastes similar to wastes in municipal or Department of Defense landfills. There is no evidence 
indicating disposal of hazardous materials. However, characterization of the wastes is not possible because solid wastes are very heterogeneous. Therefore, the assessment will focus on the surrounding soils, and wastes will not be sampled. The key decision is whether potential contamination has migrated from the cells not what the contents of the cells are.

1. Contaminant Identification - Determine, with a Yes or No answer, whether "regulated" contaminants (constituents of concern [COCs]) are present in the area surrounding (beneath) the cells. Contents of the cells will not be investigated through sampling.

2. Action level exceedance - If "regulated" contaminants are present, determine with a Yes or No answer, whether contamination exceeds EPA Region 9 PRGs, RCRA TC hazardous waste screening levels, background radiological levels or levels listed in the ORERP report (DOE/NV/10384-23) (McArthur and Miller, 1989), and the NDEP TPH action level of $100 \mathrm{ppm}$.

3. Contaminant migration - If "regulated" contaminants exceed screening levels, determine with a Yes or No answer whether regulated contaminant concentrations exceed or have the potential to exceed the spatial boundaries proposed in the conceptual model for the site.

\section{B. Identify alternative action that may be taken based on the findings of the field investigation - select the actions that will be taken based on the outcome of the field investigation that corresponds with the selected decision.}

Any alternatives will be approved by the core decision team. Alternative actions could include:

- Closure in place without further action - if contaminants are not found in the area surrounding the landfill and if it can be demonstrated that no leachate generation or migration will take place in the future

- Preparation of a Corrective Action Decision Document (CADD) which compares alternative corrective actions and selects the most appropriate corrective action - if contaminants are found above regulatory levels at the landfill. Potential remedies the CADD could address are also closure in place with or without monitoring, clean closure, or waste treatment.

- Rescoping of the characterization - if the contaminant migration exceeds the spatial boundaries and impacts groundwater 


\section{Identify relationships among decisions.}

\section{Prioritize decisions}

From highest to lowest sequence:

$$
\text { IIA. } 1>\text { IIA. } 2>\text { IIA. } 3
$$

\section{Determine the logical sequence of actions.}

1. Contaminant Identification

a. ("No" answer) Recommend that the site or the current study area is not contaminated (and will not be contaminated in the future) and that further assessment (at this location) is not necessary. This may require modeling or monitoring to provide assurance over the required time.

b. ("Yes" answer) Recommend that the current study area is contaminated and further assessment (at this location) may be warranted (i.e., determine if action levels have been exceeded). If so, go to Action 2.

2. Action Level Exceedance

a. ("No" answer) Recommend that the site or the current study area is not contaminated above applicable screening levels (and will not be contaminated further) and that further assessment (at this location) is not necessary. This may require modeling or monitoring to provide assurance over the required time.

b. ("Yes" answer) Recommend that the current study area is contaminated above applicable screening levels and further assessment (at this location) may be warranted. If so, go to Action 3.

\section{Contaminant Migration}

a. ("No" answer) Recommend that the regulated contaminant concentrations do not exceed the proposed spatial boundaries, the conceptual model does not need to be modified, and that further assessment (at this location) is not necessary. This may require modeling or monitoring to provide assurance over the required time.

b. ("Yes" answer) Recommend that the regulated contaminant concentrations exceed the proposed spatial boundary, and the model must then be modified and further assessment is required to evaluate the new (alternate) model. If so rescope for monitoring wells and/or other alternate methods presented in Attachment G. 


\section{Identify the Inputs to the Decision}

\section{A. Identify the information inputs needed to resolve the decision.}

\section{Prepare a list of all of the data needed to resolve the decision.}

a. Contaminant Identification:

- Laboratory analyses of soils directly beneath and field screening of the soils within the landfill for the parameters listed in I.C.3

- Analysis of soil gas beneath the landfill - only if laboratory analytical results detect contamination

- Soil moisture content directly below the landfill

- Soil physical characteristics (hydrological and geotechnical)

- Capacity for waste to generate leachate in the future

b. Action Level Exceedance:

Laboratory analyses of soils directly beneath and field screening of the soils within the landfill for the parameters listed in I.C.3

c. Contaminant Migration:

- Boundaries of contaminant migration from field screening and/or analyses of soils for the parameters listed in I.C. 3

- Capacity for migration to continue in the future

d. Waste Management:

Process knowledge indicates that there is no reason to believe that hazardous (i.e., RCRA-regulated) or radioactive wastes were placed in the landfill. There is no record that indicates that chemicals or solvents were discarded in the landfill. Therefore, any potential hazardous wastes placed in the landfill would be characteristic, rather than listed, wastes. The soil will be field-screened, sampled, and analyzed to verify that this process knowledge is correct. Waste generated through sampling will be traceable to its source and to individual samples. Should laboratory results indicate that the waste exhibits a hazardous characteristic, the waste will be managed as hazardous waste in accordance with RCRA. As soon as it is known that the waste is hazardous (i.e., through field screening or laboratory analyses), the waste will be managed as hazardous with the 90-day accumulation time limit starting when the waste is identified as hazardous. As soon as it is known that the waste is radioactive (i.e., through field screening or laboratory analyses), the waste will be managed in accordance with the Nevada Test Site Waste Acceptance Criteria (NTSWAC) (Rev. 0), September, 1996. As soon as it is known that the waste is a mixed waste (i.e., through field screening or laboratory analyses), the waste will be managed in accordance with the "Mutual Consent Agreement Between The State Of Nevada And The Department Of 
Energy For The Storage of Low-Level Land Disposal Restricted Mixed Waste" (6/95).

\section{Indicate how to generate the necessary data (e.g., sampling} modeling, etc.).

a. Contaminant Identification (Options):

- Laboratory analyses of soils directly beneath and field screening of the soils within the landfill for the parameters listed in I.C.3 - soil sampling and analysis

- Analysis of soil gas beneath the landfill - soil gas sampling and analysis - only if laboratory analytical results detect contamination

- Soil moisture content directly below the landfill - field screening

- Soil physical characteristics (hydrological and geotechnical) - soil sampling and analysis or in situ testing

- Capacity for waste to generate leachate in the future - water balance/leachate generation modeling. Review of historic information: vintage photos, Area 3 building inventory and build dates, hazard analysis of Area 3 facilities, contaminant types, soil characteristics, nearby well records, groundwater maps, etc.

b. Action Level Exceedance:

Same as above.

c. Contaminant Migration:

- Boundaries of contaminant migration from indicator parameters and/or analyses of soils for the parameters listed in I.C.3 - soil sampling and analysis and/or field screening

- Capacity for migration to continue in the future - contaminant distribution modeling

d. Waste Management:

Analytical results and field screening results will be used to determine if the waste is nonhazardous - soil sampling and analysis and/or field screening

B. Identify sources for each environmental input and list those inputs that are obtained through environmental measurements - identify existing sources of information that can support the decision.

See Attachment G.

C. Determine the basis for establishing contaminant-specific action level(s) list the possible basis for establishing the action level (e.g., regulatory threshold, risk or exposure assessment, technological limits, reference based, standards, etc.). 


\section{General:}

Establishment of risk-based levels through the implementation of RCRA, CERCLA, and/or ASTM risk assessment techniques, as necessary and/or appropriate.

\section{Background levels:}

Establish background levels for RCRA metals, DU/PU isotopes, and moisture prior to drilling investigation holes. (Typical TTR background levels for specific metals are presented in Culp et al, 1994.)

\section{Screening for the contaminant boundary:}

EPA Region 9 PRGs, RCRA TC hazardous waste screening levels, and NDEP TPH action level (100 ppm). Radionuclides - background radiological levels or levels listed in the ORERP report (DOE/NV/10384-23) (McArthur and Miller, 1989) for evaluation of laboratory analysis data.

\section{Solid waste regulations:}

In accordance with the techniques listed above, the State of Nevada (NAC 444.7481) will allow the suspension of requirements for monitoring groundwater (the primary ARAR) if the owner or operator can demonstrate that there is no potential for migration of hazardous constituents from that unit to the uppermost aquifer during the life of the unit, including the period of closure and postclosure. The demonstration must be certified by a qualified ground-water scientist and approved by the solid waste management authority. The demonstration must be based upon:

(a) Measurements collected at specific field sites and the sampling and analysis of physical, chemical and biological processes affecting the fate and transportation of contaminants; and

(b) Predictions of the fate and transportation of contaminants which are based on the maximum possible rate of the migration of the contaminants and $a$ consideration of the impacts on public health and safety and the environment.

\section{Waste Management:}

Listed wastes - presence above detection limits for designation (i.e., as hazardous waste) and concentrations above the LDR levels for disposal

Characteristic wastes - concentrations above the TC levels for designation and disposal 


\section{Identify potential sampling approaches and appropriate analytical methods.}

Biased samples will be collected from drillhole locations determined by geophysical anomalies. The samples will be selected from each drillhole at set intervals (5 or $10 \mathrm{ft}$ intervals) or if continuous field screening results indicate the presence of contamination. Field screening will include the following: TPH testing, VOA screening, moisture testing, and radiological screening. Soil samples collected from beneath the landfill cell will be collected as described below under sampling.

\section{Sampling:}

Sampling through subsurface drilling. The contents of each landfill cell (as determined through field screening and visual observations) and the unsaturated interval below will be investigated with multiple drilling locations from the surface to approximately 25 feet minimum and two consecutive non-detects (detections not above background levels) with field screening methods.

\section{Analytical:}

Parameters selected based on process knowledge and requirements specified by the NDEP for "full suite" analysis:

Total VOCs - SW-846 (EPA, 1992) 8240

Total SVOCs - SW-846 (EPA, 1992) 8270

Total RCRA metals - SW-846 (EPA, 1992) 6010/7470

Total petroleum hydrocarbons - gasoline, diesel, and oil fractions - SW-846 (EPA, 1992) 8015 modified

PCB/Pesticides - SW-846 (EPA, 1992) 8080

Gamma spectroscopy -HASL 300 4.5.2.3 (DOE, 1992)

Isotopic uranium and plutonium - National Academy of Sciences, Nuclear Science Series (NAS -NS)-3050 and -3058, respectively

(TC [SW-846 1311] analyses will be performed on samples if waste is determined to be RCRA)

The following laboratory contaminants (constituents) are commonly detected in analytical sample results and may appear in sample results for these activities.

For VOCs:

Acetone

Methylene chloride

MEK

Toluene 
For SVOCs:

Phthalate esters (i.e., bis[2-ethylhexyl]phthalate)

An off-site, fixed-base laboratory may be used for the following soil engineering analysis:

Initial moisture content

Dry bulk density

Calculated porosity

Saturated/unsaturated hydraulic conductivity

Particle size distribution - preferred method is hydrometer distribution

Water release (retention) curve

or in situ testing may be performed for soil characteristics.

\section{Define the Boundaries of the Study}

\section{A. Define the geographic areas of the field investigation}

1. Define the domain or geographic area within which all decisions must apply (in some cases this may be defined by the Operable Unit). Each landfill cell (i.e., A3-1, A3-2, etc) will be treated as an independent study area. The study area is defined by the plan view of the associated geophysical anomalies plus $3 \mathrm{~m}(10 \mathrm{ft})$ on each side as a buffer zone. The studies may be performed simultaneously at the cells for economies of scale, but the decision process will be applied separately for each cell.

2. Specify the characteristics that define the population of interest. Alluvial sediments in the unsaturated zone

3. When appropriate, divide the population into strata that have relatively homogeneous characteristics.

The site (cell) can be divided into three strata: (1) soils, surface (landfill cell surface) to 25 feet below ground surface (the area most likely to be impacted by potential contamination); (2) unsaturated soil deeper than 25 feet (less likely to be contaminated due to limited precipitation, lack of liquids disposal at landfills, and high evapotranspiration); and (3) groundwater.

The sampling operation for strata 1 (the first $25 \mathrm{ft}$ ) will consist of obtaining/logging field screening results from within the landfill down to the bottom of the landfill $(0 \mathrm{ft}$ to approximately $15 \mathrm{ft}$ ) and sample collection every $5 \mathrm{ft}$ from the bottom of the landfill to $25 \mathrm{ft}$ below ground surface. 
After 25 feet, strata 2, the sampling interval will be decreased to 10 -foot intervals to the total depth. Total depth will be determined by the collection of two consecutive non-detects (detections not above background levels) with field screening methods.

If contaminants extend to groundwater, the DQOs and project will be rescoped by the core decision team.

\section{Define the scale of decision making.}

The scale of decision making will be based on the strata into which the site has been divided and the length of time required by ARARs. Precision of the migration into the first strata will be determined within the 5-foot intervals, and modeling will be used to predict future migration potential. The lower strata will be determined within 10-foot intervals.

\section{B. Define the temporal boundaries of the decision.}

\section{Determine the time frame to which the study data apply.}

The beginning of the time frame for each landfill cell is the date the cell was originally opened (see the Timeline - Attachment C). Study data will include process knowledge to include all available validated (i.e., source of information can be traced and verified) documentation regardless of age of information.

The end of the time frame will be contingent on the decision regarding closure status (i.e., No Further Action, clean closure, or closure in place with postclosure monitoring [ 30 years] or monitoring waivers). The NDEP will be notified if the schedule has been negatively impacted beyond recovery. The NDEP will also be notified weekly on the Daily Summary (generated during field activities) whether the project is on schedule or not.

\section{Determine when to collect data.}

Seasonal variations are not expected to affect data quality or representativeness, and activities can be conducted as scheduled. Soil gas monitoring will be affected by diurnal variations and should be designed accordingly.

Characterization activities will be conducted only during favorable weather conditions (i.e., no rain, no significant wind); however, engineering controls may be used to improve conditions.

C. Identify any practical constraints on data collection.

- Testing operations (TTR security constraints)

- Meteorological

- Health and safety 


\section{Develop a Decision Rule - Define a Logical Basis for Choosing Among Alternative Actions}

A. Specify the parameter that characterizes the population of interest. Leachate within unsaturated alluvial soils $25 \mathrm{ft}$ beneath and within $10 \mathrm{ft}$ horizontally from the sides of the landfill cells.

B. Specify the action level or preliminary action level for the decision. The action levels trigger the "yes" decisions described in Step II, and they include:

\section{On-site field screening methods (if on-site screening methods are} used)

- Radiation levels 2 times background levels

- VOC screening (20 ppm or 2.5 times background, whichever is greater)

- TPH above $100 \mathrm{ppm}$ from a field screening method that can obtain a comparable reading or above the field screening level that is comparable to an analytical concentration of $100 \mathrm{ppm} \mathrm{TPH}$

\section{Off-site - Analytical (laboratory)}

- Contaminant concentrations above the EPA Region 9 PRGs or background, whichever is higher, for initial site screening and characterization and above risk-based levels (modeling - which may be different)

- Laboratory TPH concentrations above $100 \mathrm{ppm}$

- Application of background radiological levels or levels listed in the ORERP report (DOE/NV/10384-23) (McArthur and Miller, 1989) for evaluation of laboratory analysis data

C. Develop the decision rule - Combine the outputs of the previous DQO steps into "if ... then ..." decision rules that include the parameters of interest, the action levels, and the alternative actions.

\section{Contaminant Identification:}

If the field screening and verification samples (laboratory analyses) do not detect potential contaminants above preliminary action levels, then recommend that the current study area (cell) is not contaminated (and will not be contaminated in the future) and that further assessment (at this location) is not necessary. This may require modeling or monitoring to provide assurance over the required time. 


\section{DATA QUALITY OBJECTIVES WORKSHEETS}

If the field screening and verification samples (laboratory analyses) detect potential contaminants, then further assessment (at this location) may be warranted (i.e., determine if action levels have been exceeded). If so, go to action level exceedance assessment.

\section{Action Level Exceedance:}

If the verification samples (laboratory analyses) do not detect potential contaminants above action levels and modeling shows no future increase in concentrations, then recommend that the current study area is not contaminated above applicable levels (and will not be contaminated further) and that further assessment (at this location) is not necessary. This may require modeling or monitoring to provide assurance over the required time.

If the verification samples (laboratory analyses) detect contaminants above action levels or modeling shows future increase in concentrations above action levels, then recommend that the current study area is or may be contaminated above applicable levels and further assessment (at this location) may be warranted. If so, go to contaminant migration assessment.

\section{Contaminant Migration:}

If the verification samples (laboratory analyses) do not detect potential contaminants above action levels beyond the boundaries, recommend that the regulated contaminant concentrations do not exceed the proposed spatial boundaries, the conceptual model does not need to be modified, and that further assessment (at this location) is not necessary. Prepare a CADD for site closure.

If the verification samples (laboratory analyses) detect contaminants above action levels beyond the boundaries, recommend that the regulated contaminant concentrations exceed the proposed spatial boundary and the model must then be modified and further assessment is required to evaluate the new (alternate) model. If so, rescope for monitoring wells, and/or other alternate methods presented in Attachment G.

\section{Specify Acceptable Limits on Decision Errors - Specify Decision Error Limits Based on the Consideration of the Consequences of Making an Incorrect Decision}

Because the sampling approach relies entirely on biased samples, no statistical analysis is proposed. If statistical analysis can be performed, the following will be applied to the decision process. 
A. Determine the upper and lower bounds for the parameter of interest using relevant historical site data.

In the unlikely event the contaminants are present, they are expected to be similar to leachate compositions from municipal solid waste landfills.

B. Define both types of decision errors and identify the potential consequences of each.

1. Using the actions, action level, and decision rule(s), define both types of decision errors.

The two types of decision errors are paired results of the decisions discussed above.

a. Contaminant Identification:

(1) "Regulated" contaminants are determined not to be present when they really are.

(2) "Regulated" contaminants are determined to be present when they really are not.

b. Action Level Exceedance:

(1) "Regulated" contaminants do not exceed action levels when they really do.

(2) "Regulated" contaminants exceed action levels when they really do not.

c. Contaminant Migration:

(1) "Regulated" contaminants are not migrating when they really are.

(2) "Regulated" contaminants are migrating when they really are not.

d. For each set of decision errors described above, the worst-case consequences are that waste constituents will, unintentionally, be left in place. The lesser error will cause resources to be expended unnecessarily.

\section{Establish the true state of nature for each decision error.}

a. Contaminant Identification - If regulated contaminants are present, they will be within the current study areas.

b. Contaminant characterization - The contamination exceeds or will exceed EPA Region 9 PRGs, background radiological levels or levels listed in the ORERP report (DOE/NV/10384-23) (McArthur and Miller, 1989) and the NDEP TPH action level $(100 \mathrm{ppm})$ applicable to the site or the current study area under investigation.

c. Contaminant migration - Regulated contaminant concentrations exceed or will exceed the spatial boundaries proposed in the conceptual model for the site. 
3. Define the true state of nature for the more severe decision error as the baseline condition or the null hypothesis $\left(H_{0}\right)$ and define the true state of nature for the less severe decision error as the alternative hypothesis $\left(H_{a}\right)$.

a. Contaminant Identification:

(1) $\mathrm{H}_{0}-$ Regulated contaminants are or will be present within the current study areas.

(2) $\mathrm{H}_{\mathrm{a}}$ - Regulated contaminants are not and will not be present within the current study areas.

b. Action Level Exceedance:

(1) $\mathrm{H}_{0}$ - The contamination exceeds or will exceed EPA Region 9 PRGs, background radiological levels, or levels listed in the ORERP report (DOE/NV/10384-23), (McArthur and Miller, 1989) and the NDEP TPH action level of $100 \mathrm{ppm}$.

(2) $\mathrm{H}_{\mathrm{a}}$ - The contamination does not and will not exceed EPA Region 9 PRGs, background radiological levels, or levels listed in the ORERP report (DOE/NV/10384-23), (McArthur and Miller, 1989) and the NDEP TPH action level of $100 \mathrm{ppm}$.

c. Contaminant Migration:

(1) $\mathrm{H}_{\mathrm{o}}$ - Regulated contaminant concentrations exceed or will exceed the spatial boundaries proposed in the conceptual model for the site.

(2) $\mathrm{H}_{\mathrm{a}}$ - Regulated contaminant concentration do not and will not exceed the spatial boundaries proposed in the conceptual model for the site.

\section{Assign the terms "false positive" and "false negative" to the proper decision errors.}

a. Contaminant Identification:

(1) False positive - "Regulated" contaminants are not and will not be present within the current study areas when they really are.

(2) False negative - "Regulated" contaminants are or will be present within the current study areas when they really are not.

b. Contaminant Characterization:

(1) False positive - "Regulated" contaminants do not exceed action levels when they really do.

(2) False negative -"Regulated" contaminants exceed action levels when they really do not. 
c. Contaminant Migration:

(1) False positive - "Regulated" contaminant concentrations do not and will not exceed the spatial boundaries proposed in the conceptual model for the site when they really do and will.

(2) False negative - "Regulated" contaminant concentrations exceed or will exceed the spatial boundaries proposed in the conceptual model for the site when they really do not and will not.

C. Specify a range of possible parameter values where the consequences of decision errors are relatively minor (the gray region) - identify the range of points on the false negative side of the action level where the consequences of making a decision errors are relatively minor: This range establishes the gray region.

Not applicable, the biased sampling approach is not suitable for statistical analysis. However, the gray area will be those samples just above detection limits or background levels, whichever is higher, for the contaminant identification decision. For the action level exceedance and the contaminant migration decisions, the gray area will be those results very close to the action levels.

D. Assign probability values to points above and below the action level that reflect the acceptable probability for the occurrences of decision errors.

Because the sampling approach relies entirely on biased samples, no statistical analysis is proposed. If statistical analysis can be performed (e.g., gridded sampling results), the probability values will be established at a 95 percent confidence level above and below the gray area.

\begin{tabular}{|c|c|c|c|c|}
\hline $\begin{array}{c}\text { True } \\
\text { Concentration }\end{array}$ & Correct Decision & Type of Error & $\begin{array}{c}\text { Tolerable } \\
\text { Probability of } \\
\text { Incorrect Decision }\end{array}$ & $\begin{array}{c}\text { Level of } \\
\text { Confidence }\end{array}$ \\
\hline \hline$<80 \%$ action level & Not exceeded & False Negative & $5 \%$ & $95 \%$ \\
\hline $\begin{array}{c}80 .-100 \% \text { action } \\
\text { level }\end{array}$ & Not exceeded & False Negative & Gray Region & Gray Region \\
\hline$>100 \%$ action level & Does exceed & False Positive & $5 \%$ & $95 \%$ \\
\hline
\end{tabular}

E. Check for consistency - check the limits on decision errors to ensure that they accurately reflect the decision maker's concerns about the relative consequences for each type of decision error. 


\section{DATA QUALITY OBJECTIVES WORKSHEETS}

No statistical analysis is proposed. If statistical analyses are performed, the limits will also require formal approval during the internal and NDEP review process.

\section{Optimize the Design - Outline a Sampling Design, Specifying the Operational Details of the Sampling Plan which Falls within the Project's Constraints}

Note: The information presented within this section is the result of discussions held between both the core decision team members and the scoping team members on December 11, 1996. Discussions were based on the subsections of Step VII.

The sampling approaches for individual Area 3 subareas (CASs) are presented in the Area 3 Sampling Program table. Recommended boring locations and rationale are described and the boring locations are shown in Figures 1 through 8 . Each boring will be screened and sampled for the parameters described in Steps III.D. and V.B. The borings will be sampled at intervals described in IV.A.3.

\section{Key Assumptions:}

- The cells were normally excavated by bulldozer or similar earthmoving equipment and are, therefore, about 12 to 15 feet wide and 100 to 150 feet long with relatively steep, linear sides and at least one end (or both) is gradually sloped, ramped.

- The cells are assumed to be 12 to $15 \mathrm{ft}$ in depth based on the depth of the Roller Coaster Lagoon Trench (DOE/NV, 1996b). The deepest area of the trench is expected to be the middle third of the trench.

- We have more control on the width of the cells than the length. Using the 12-to 15-foot assumptions, the geophysics appear to be accurate within about 7 to 10 feet on each side because the anomalies are about 30 to 40 feet wide.

- On the magnetic field plots, the anomalies represent magnetic materials (steel, iron, or mafic rocks) and do not necessarily give an accurate indication of the size of the object. Generally, the more distinct the anomaly, the greater the quantity.

- On the conductivity plots, the distinct anomalies generally represent manmade, conductive media (metallic debris), but anomalies can also represent natural conditions (moisture, salts, muds).

- Multiple cell landfills are generally excavated parallel to subparallel. 
- The locations described in the Area 3 Sampling Program table may need to be adjusted in the field based on additional field observations.

Note:

- The metallic anomalies being investigated will be designated on site figures included in the Corrective Action Investigation Plan (CAIP) to show the area under investigation. One black and white copy of the geophysical data used to interpret the locations for the trenches/borings will be included in the CAIP, per site.

- The operational details and assumptions of the selected design will be contained in the sampling and analysis section of the CAIP.

- Work will be conducted on those sites with contingency borings (A3-1, A3-7, and A3-8) first so that lab data can be obtained prior to drilling demobilization. 


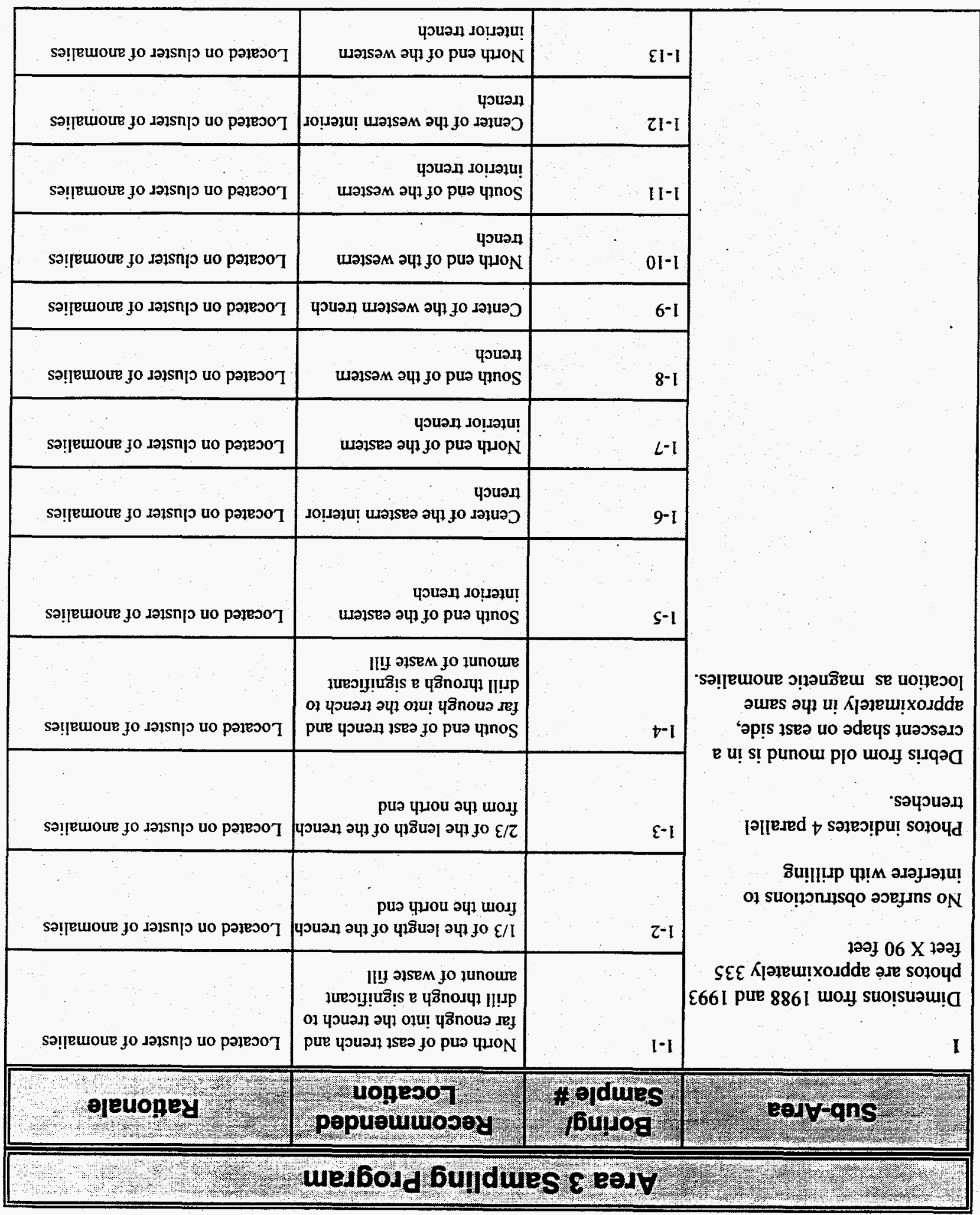




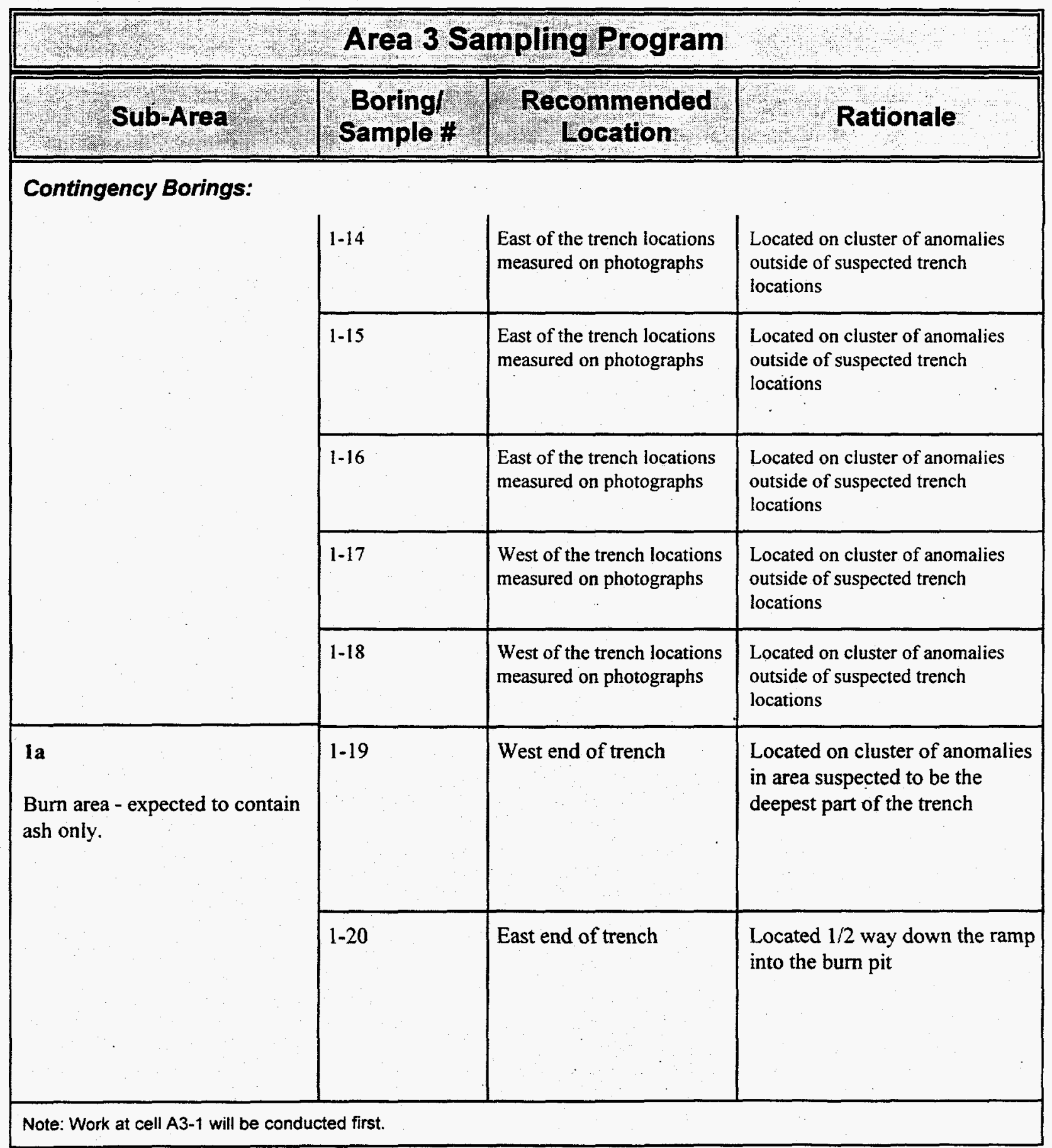




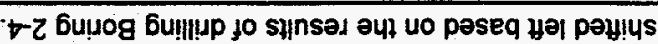

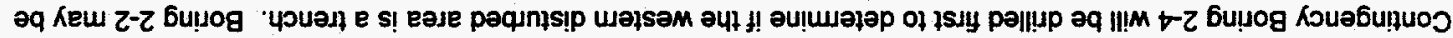

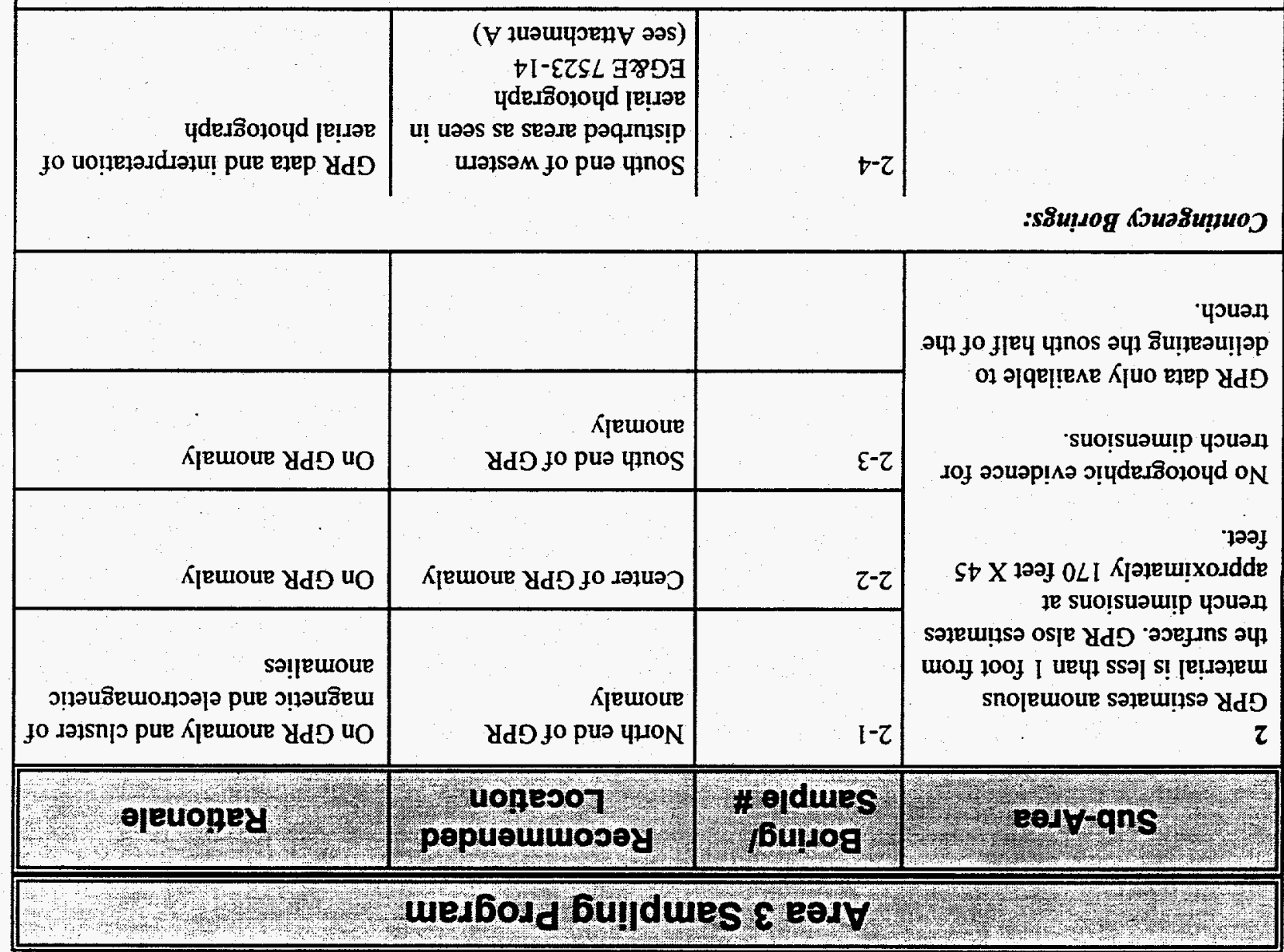




\begin{tabular}{|c|c|c|c|}
\hline \multicolumn{4}{|c|}{\begin{tabular}{|l|l|} 
Area 3 Sampling Program \\
\end{tabular}} \\
\hline $\begin{array}{c}\text { Sub-area } \\
\end{array}$ & $\begin{array}{l}\text { Boring } \\
\text { Sample } 7\end{array}$ & $\begin{array}{l}\text { Recommended } \\
\text { focation }\end{array}$ & Rationale \\
\hline \multirow{4}{*}{$\begin{array}{l}3^{a} \\
\text { Pipes and fence obscure the } \\
\text { geophysical data. } \\
\text { The fence is the only surface } \\
\text { obstruction which might } \\
\text { interfere with drilling, but the } \\
\text { subsurface pipe must be avoided. }\end{array}$} & $3-1$ & $\begin{array}{l}\text { North end of the west } \\
\text { trench }\end{array}$ & Located on anomaly group \\
\hline & $3-2$ & $\begin{array}{l}\text { North side of fence which } \\
\text { bisects the trench }\end{array}$ & $\begin{array}{l}\text { Located on magnetic anomaly } \\
\text { only }\end{array}$ \\
\hline & $3-3$ & $\begin{array}{l}\text { South side of fence which } \\
\text { bisects the trench }\end{array}$ & Located on anomaly group \\
\hline & $3-4$ & $\begin{array}{l}\text { South end of the west } \\
\text { trench }\end{array}$ & Located on anomaly group \\
\hline \multirow{3}{*}{$\begin{array}{l}\text { No photographic evidence for } \\
\text { trench location and size. }\end{array}$} & $3-5$ & $\begin{array}{l}\text { North end of the east } \\
\text { trench }\end{array}$ & Located on anomaly group \\
\hline & $3-6$ & Center of the east trench & Located on anomaly group \\
\hline & $3-7$ & $\begin{array}{l}\text { South end of the east } \\
\text { trench }\end{array}$ & Located on anomaly group \\
\hline \multirow{2}{*}{$\begin{array}{l}\text { Southeastern Subarea } \\
\text { Subsurface pipe partially } \\
\text { obscures anomaly and may } \\
\text { interfere with drilling. } \\
\text { No photographic evidence }\end{array}$} & 3-8 & $\begin{array}{l}\text { Northeast portion of } \\
\text { possible pits }\end{array}$ & $\begin{array}{l}\text { Located on conspicuous } \\
\text { anomaly group }\end{array}$ \\
\hline & $3-9$ & $\begin{array}{l}\text { Southwest portion of } \\
\text { possible pits }\end{array}$ & $\begin{array}{l}\text { Located on conspicuous } \\
\text { anomaly group }\end{array}$ \\
\hline$e:{ }^{a} n$ & & pits. & \\
\hline
\end{tabular}


DATA QUALITY OBJECTIVES WORKSHEETS

\begin{tabular}{|c|c|c|c|}
\hline \multicolumn{4}{|c|}{ 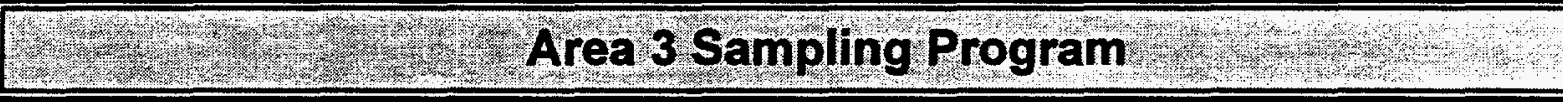 } \\
\hline Sub-Area & $\begin{array}{l}\text { Boringl } \\
\text { Sample } 4\end{array}$ & $\begin{array}{l}\text { Recommended } \\
\text { Location }\end{array}$ & Rationale \\
\hline \multirow{8}{*}{$\begin{array}{l}4 \\
\text { Vintage photos indicate trench } \\
\text { dimensions. } \\
\text { Access road is to the north, and } \\
\text { the ramp will be on the north for } \\
\text { both trenches. }\end{array}$} & $4-1$ & $\begin{array}{l}\text { North end of the western } \\
\text { trench }\end{array}$ & Located on anomaly cluster \\
\hline & $4-2$ & $\begin{array}{l}1 / 3 \text { of the way from the } \\
\text { north end of the western } \\
\text { trench }\end{array}$ & Located on anomaly cluster \\
\hline & $4-3$ & $\begin{array}{l}\text { Center of the western } \\
\text { trench }\end{array}$ & Located on anomaly cluster \\
\hline & 4-4 & $\begin{array}{l}2 / 3 \text { of the way from the } \\
\text { north end of the western } \\
\text { trench }\end{array}$ & Located on anomaly cluster \\
\hline & $4-5$ & $\begin{array}{l}\text { South end of the western } \\
\text { trench }\end{array}$ & Located on anomaly cluster \\
\hline & $4-6$ & $\begin{array}{l}\text { Approximate center of the } \\
\text { eastern trench }\end{array}$ & Located on anomaly cluster \\
\hline & $4-7$ & $\begin{array}{l}\text { South end of the eastern } \\
\text { trench }\end{array}$ & Located on anomaly cluster \\
\hline & 4-8 & $\begin{array}{l}\text { Northeast of the trenches } \\
\text { near the road }\end{array}$ & Located on anomaly cluster \\
\hline
\end{tabular}




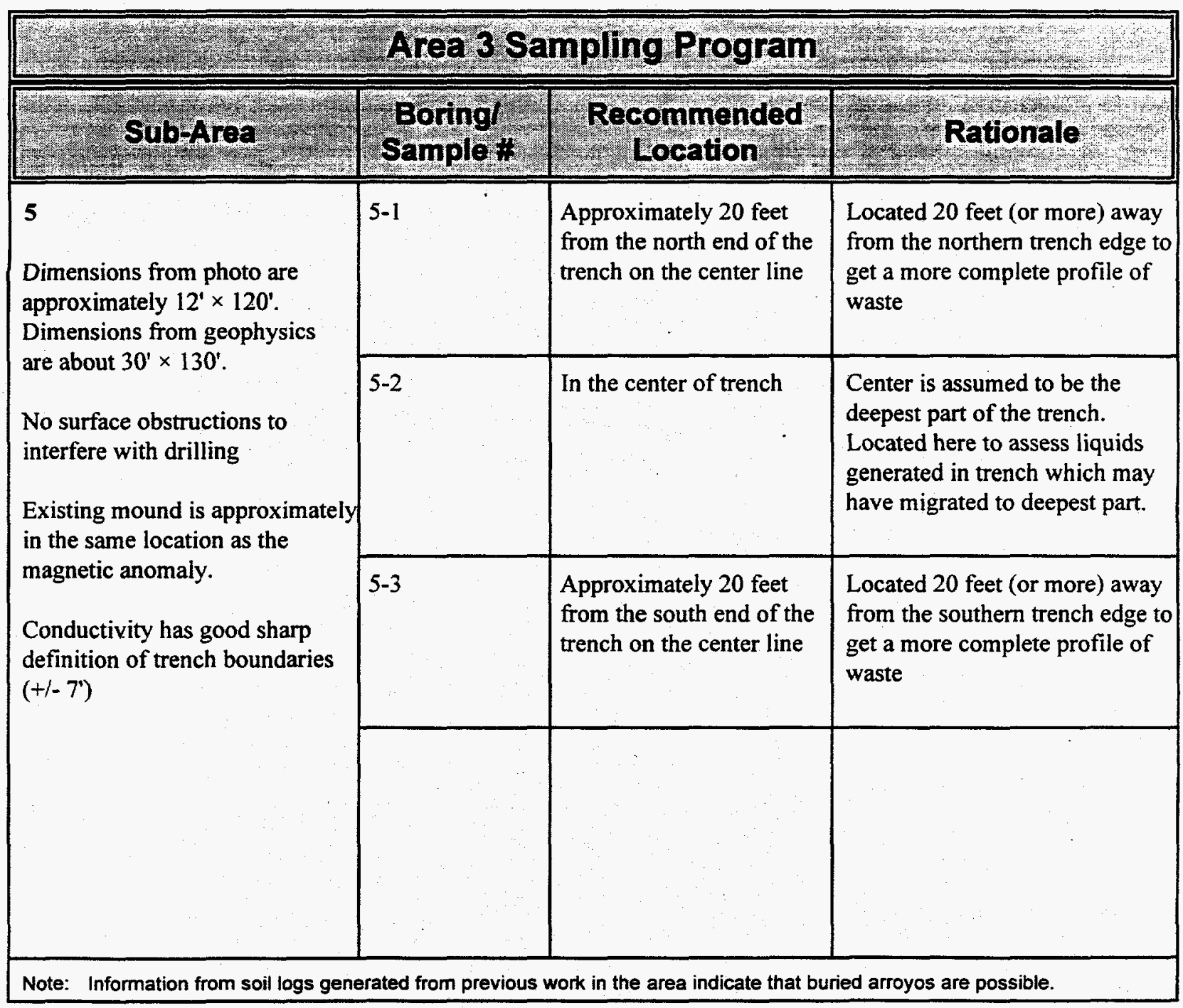




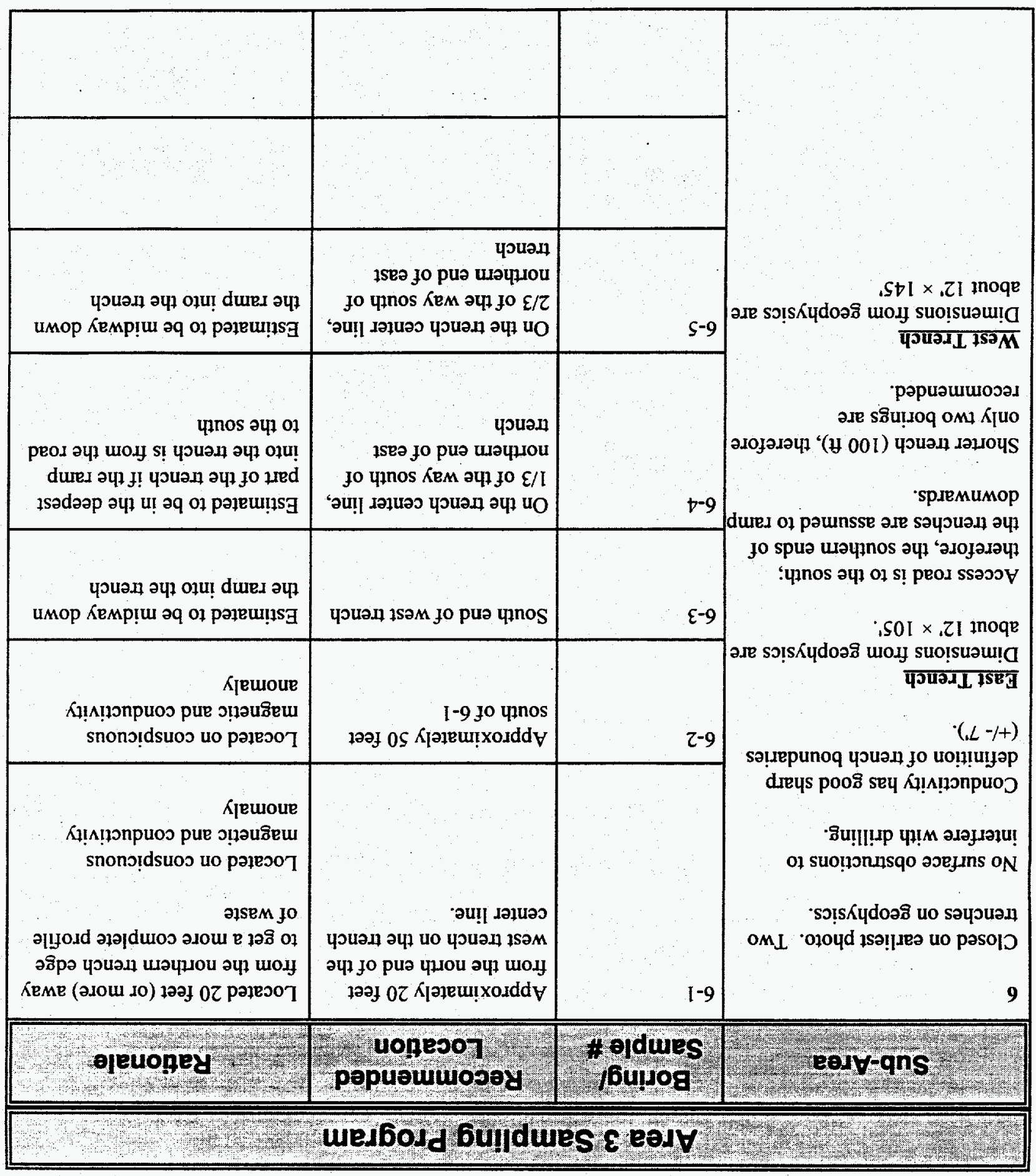




\begin{tabular}{|c|c|c|c|}
\hline \multicolumn{4}{|c|}{ Area 3 Sampling Program } \\
\hline Sub-Aroa & $\begin{array}{l}\text { Boring } \\
\text { Samplet }\end{array}$ & $\begin{array}{l}\text { Recommended } \\
\text { trocationt }\end{array}$ & Rationale \\
\hline $\begin{array}{l}7 \\
\text { Key assumptions about trench } \\
\text { dimensions do not hold for this } \\
\text { subarea. }\end{array}$ & $7-1$ & $\begin{array}{l}\text { Center of conductivity } \\
\text { anomaly }\end{array}$ & $\begin{array}{l}\text { Located in center of } \\
\text { conductivity anomaly to assess } \\
\text { material type and composition }\end{array}$ \\
\hline $\begin{array}{l}\text { subarea. } \\
\text { No magnetic anomalies } \\
\text { observed. Disturbed area on } \\
\text { surface only, approximately } \\
100 \mathrm{ft} \times 300 \mathrm{ft} \\
\text { No surface obstructions to } \\
\text { interfere with drilling }\end{array}$ & Contingency & orings: & $\begin{array}{l}\text { No hazardous materials } \\
\text { expected. Contingency borings } \\
\text { recommended for use in } \\
\text { determining margins of anomaly } \\
\text { in case } 7-1 \text { encounters } \\
\text { contaminated materials. }\end{array}$ \\
\hline $\begin{array}{l}\text { Conductivity plots show broad } \\
\text { area of higher conductivity } \\
\text { anomaly estimated to be at } \\
\text { depth. }\end{array}$ & $7-3$ & TBD & $\begin{array}{l}\text { No hazardous materials } \\
\text { expected. Contingency borings } \\
\text { recommended for use in } \\
\text { determining margins of anomaly } \\
\text { in case } 7-1 \text { encounters } \\
\text { contaminated materials. }\end{array}$ \\
\hline & & & \\
\hline
\end{tabular}




\section{DATA QUALITY OBJECTIVES WORKSHEETS}

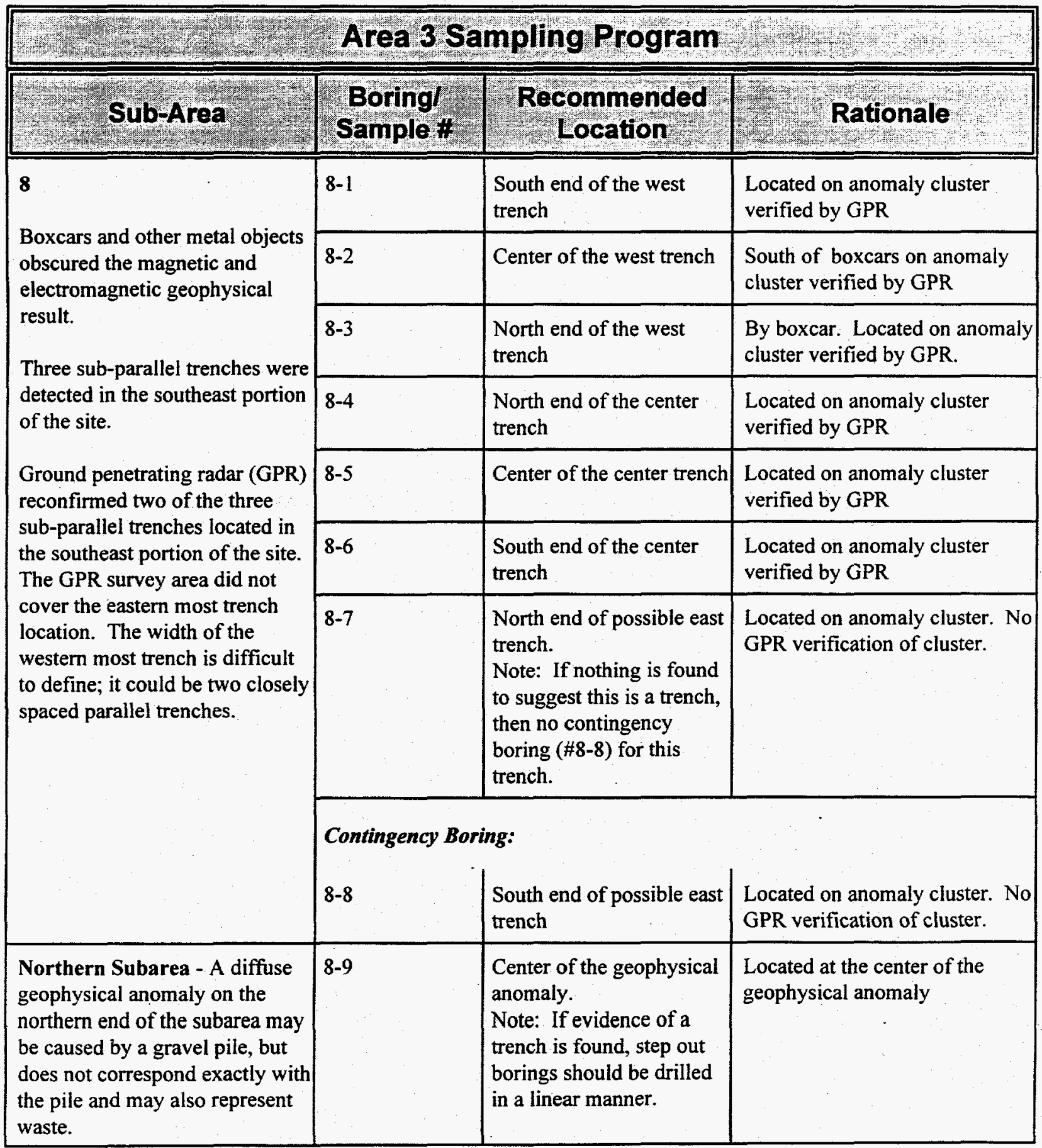




\begin{tabular}{|c|c|c|c|}
\hline Sub-Aroa & Sample & $\begin{array}{l}\text { Recommended } \\
\text { Location }\end{array}$ & Wationale \\
\hline \multirow{4}{*}{$\begin{array}{l}\text { Background } \\
\text { Borings are located in } \\
\text { undisturbed areas, are widely } \\
\text { spaced to assess background } \\
\text { variability, and should represent } \\
\text { as many subareas as possible. } \\
\text { Care will be taken in the field to } \\
\text { drill in undisturbed areas. } \\
\text { Borings may be moved up to } \\
100 \mathrm{ft} \text { from positions shown on } \\
\text { map. } \\
\text { Samples for metals and rad will } \\
\text { be taken at } 10 \text {-foot and } 15 \text {-foot } \\
\text { intervals to assess approximately } \\
\text { the same depths as the landfill } \\
\text { cell bottoms. }\end{array}$} & B-1 & $\begin{array}{l}\text { Approximately } 500 \text { feet } \\
\text { west of Subarea } 2\end{array}$ & $\begin{array}{l}\text { Centrally located between } \\
\text { Subareas } 1,2,5 \text {, and } 6 \text {. In } \\
\text { similar topography, away from } \\
\text { major drainage which might } \\
\text { bias metals results. }\end{array}$ \\
\hline & B-2 & $\begin{array}{l}500 \text { feet south and } 200 \\
\text { feet west of the center of } \\
\text { Subarea } 6\end{array}$ & $\begin{array}{l}\text { Centrally located between } \\
\text { Subareas } 5,6 \text { and } 8\end{array}$ \\
\hline & B-3 & $\begin{array}{l}160 \text { feet north-northwest } \\
\text { of the center of Subarea } 7\end{array}$ & $\begin{array}{l}\text { Adjacent to Subarea } 7 \text { which is } \\
\text { isolated on the east side of } \\
\text { Area } 3\end{array}$ \\
\hline & & & \\
\hline \multicolumn{4}{|c|}{$\begin{array}{l}\text { Note: If something is found in these borings and/or backgrounds vary significantly, then additional background borings will be } \\
\text { needed. } \\
\text { See Figure } 8 \text { for approximate background boring locations. }\end{array}$} \\
\hline
\end{tabular}




\section{DATA QUALITY OBJECTIVES WORKSHEETS}

\section{References}

Culp, T., D. Howard, Y..McClellan. 1994. 1993 Site Environmental Report Tonopah Test Range, Tonopah, Nevada, SAND94-1292. Las Vegas, NV.

DOE, see U.S. Department of Energy.

DOE/NV, see U.S. Department of Energy, Nevada Operations Office.

Ecology and Environment, Inc. 1989. Federal Facility Preliminary Assessment Review, Tonopah Test Range, Nye County, Nevada, 31 August. Las Vegas, NV. (Attached to a memorandum from Richard F. Sena [US DOE/AL] to Al Chernoff [US DOE/AL], MSD dated 1990.)

EG\&G Energy Measurements. 1980-1993. Aerial photographs from EG\&G/EM Remote Sensing Laboratory archives, Perf. Numbers 3310-20, 4107-4, 5065-17, 5438-52, 5376-47, 5957-23, 7523-14. Las Vegas, NV.

EPA, see U.S. Environmental Protection Agency.

ERDA, see U.S. Energy Research \& Development Administration.

IT, see IT Corporation.

IT Corporation. Pre-1962, 1962. Aerial photographs contained in ITLV Project files, Library Reference Numbers 5489, 5490, 5488.

IT Corporation. 1994. Inspection of Building Structures at Sandia National Laboratories/Tonopah Test Range, ITLV 3232TTR, August. Las Vegas, NV.

IT Corporation. 1996. Geophysical Survey Field Data for Area 3 Landfill Cells A3-3, A3-5, A3-6, A3-7, and A3-8, Tonopah Test Range, November.

IT Corporation. 1997. Initial Surface Geophysical Survey Report for the Tonopah Test Range Environmental Restoration Sites, DOE/NV/10972-93. Las Vegas, NV.

Karas, Paul. 1993a. Transcripts of TTR ER Interviews between Robert Statler (Former TTR Range Manager), J. Quas (REECo), S. Galvin (REECo), R. Dubiskas (IT), D. Howard (RSN), and P. Karas (CDM Federal), 19 May. Las Vegas, NV. 
Karas, Paul. 1993b. Transcripts of TTR ER Interviews between Robert Statler (Former TTR Range Manager), R. Dubiskas (IT), D. Howard (RSN), and P. Karas (CDM Federal), 28 June. Las Vegas, NV.

McArthur, R. D. and Miller, F.L., Jr. Desert Research Institute. University of Nevada Las Vegas. 1989. Offsite Radiation Exposure Review Project (ORERP), Phase II Soils Programs, DOE/NV/10384-23. Las Vegas, NV.

Phelan, J. M. 1988. Transmittal to Distribution regarding Environmental Restoration Program status for satellite facilities, 17 May. Las Vegas, NV.

SNL, see Sandia National Laboratories.

Sandia National Laboratories. 1992. Tonopah Test Range Facility Reports, ITLV 1709TTR. Las Vegas, NV.

Quas, John. 1993. Meeting with Randy Dubiskas and Ed Mignardot for IT Corporation, 27 July.

U.S. Department of Energy. 1992. Environmental Measurements Laboratory Procedure Manual, HASL-300, 27th Edition, Volume 1. New York, NY.

U.S. Department of Energy Nevada Operations Office. 1996a. Corrective Action Unit Work Plan, Tonopah Test Range, Nevada. Las Vegas, NV.

U.S. Department of Energy Nevada Operations Office. 1996b. Corrective Action Investigation Plan: Roller Coaster Lagoons and North Disposal Trench, Tonopah Test Range, Revision 1. Las Vegas, NV.

U.S. Energy Research \& Development Administration. 1975. Environmental Assessment Tonopah Test Range Tonopah, Nevada. Las Vegas, NV.

U.S. Environmental Protection Agency. 1992. Test Methods for Evaluating Solid Waste, Physical/Chemical Methods, SW-846, PB89-148076. Washington; DC.

U.S. Environmental Protection Agency. 1994. Guidance for the Data Quality Objectives Process (EPA QA/G4). Washington, DC.

West, Gary. 1987. Meeting notes between G. West (SNL), C. Lang (SNL), and J. St Clair (SNL), August. Las Vegas, NV. 


\section{DATA QUALITY OBJECTIVES WORKSHEETS}

Figure 2

Proposed Boring Locations, Area 3 Landfill Cell A3-3

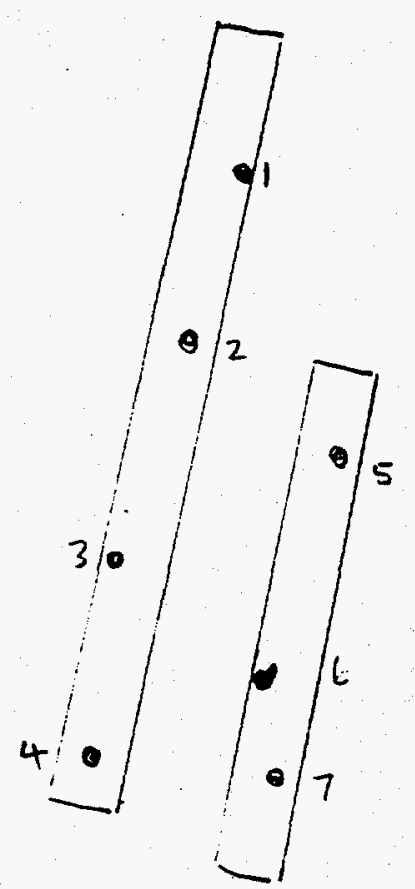

KEY

-1 PROPOIER BORANG LOCATION

\section{A3-3}

Poss. pits

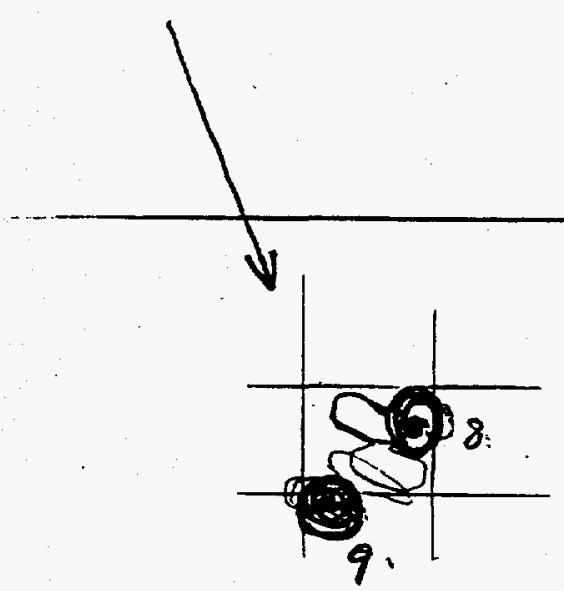

306

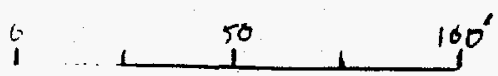

FIGURE 2

Proposed BorING LOCATIONS

Area 3 LANDATLL CELL A3-3 
CAIP CAU No. 424

Section: Appendix A

Revision: 0

Date: $04 / 25 / 97$

Page 37 of 68

DATA QUALITY OBJECTIVES WORKSHEETS

Figure 3

Proposed Boring Locations, Area 3 Landfill Cell A3-4

A-y Prop. Lac.

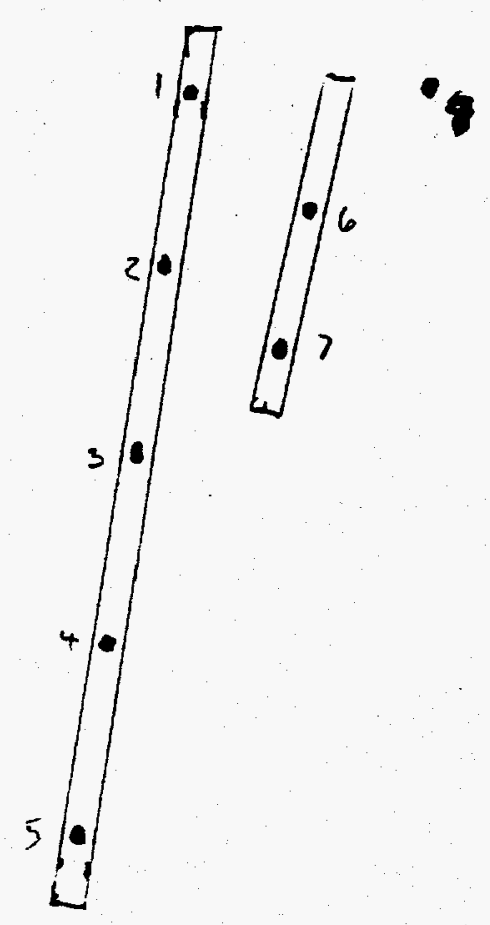

Source: DOE NV, 1994

KEY

PRoposed Boring LOCATION

Figure 3

Proposed Boreas Locations

area 3 landfill Cell A3-4 
Figure 4

Proposed Boring Locations, Area 3 Landfill Cell A3-5

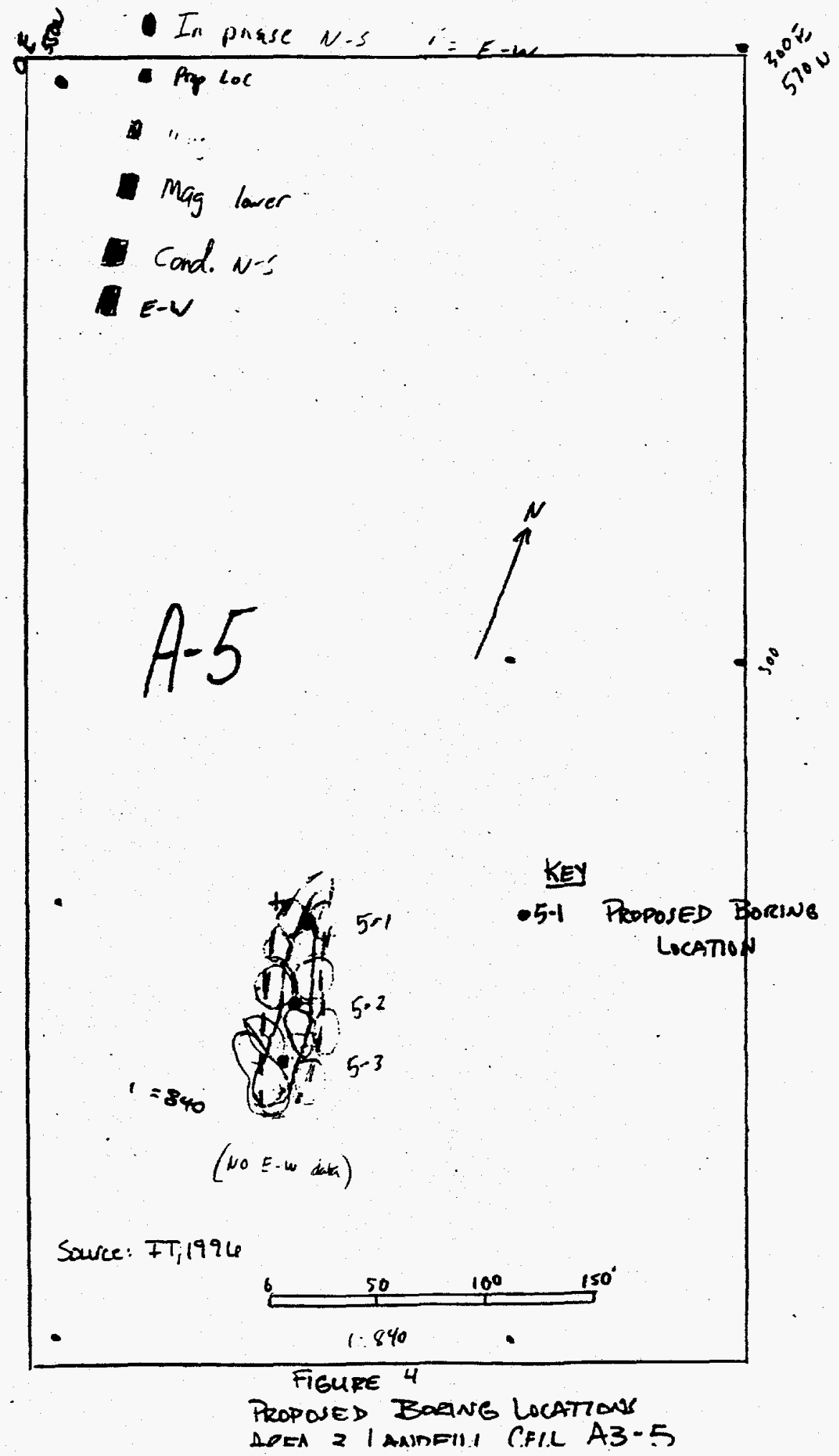


CAIP CAU No. 424

Section: Appendix A

Revision: 0

Date: $04 / 25 / 97$

Page 39 of 68

DATA QUALITY OBJECTIVES WORKSHEETS

Figure 5

Proposed Boring Locations, Area 3 Landfill Cell A3-6

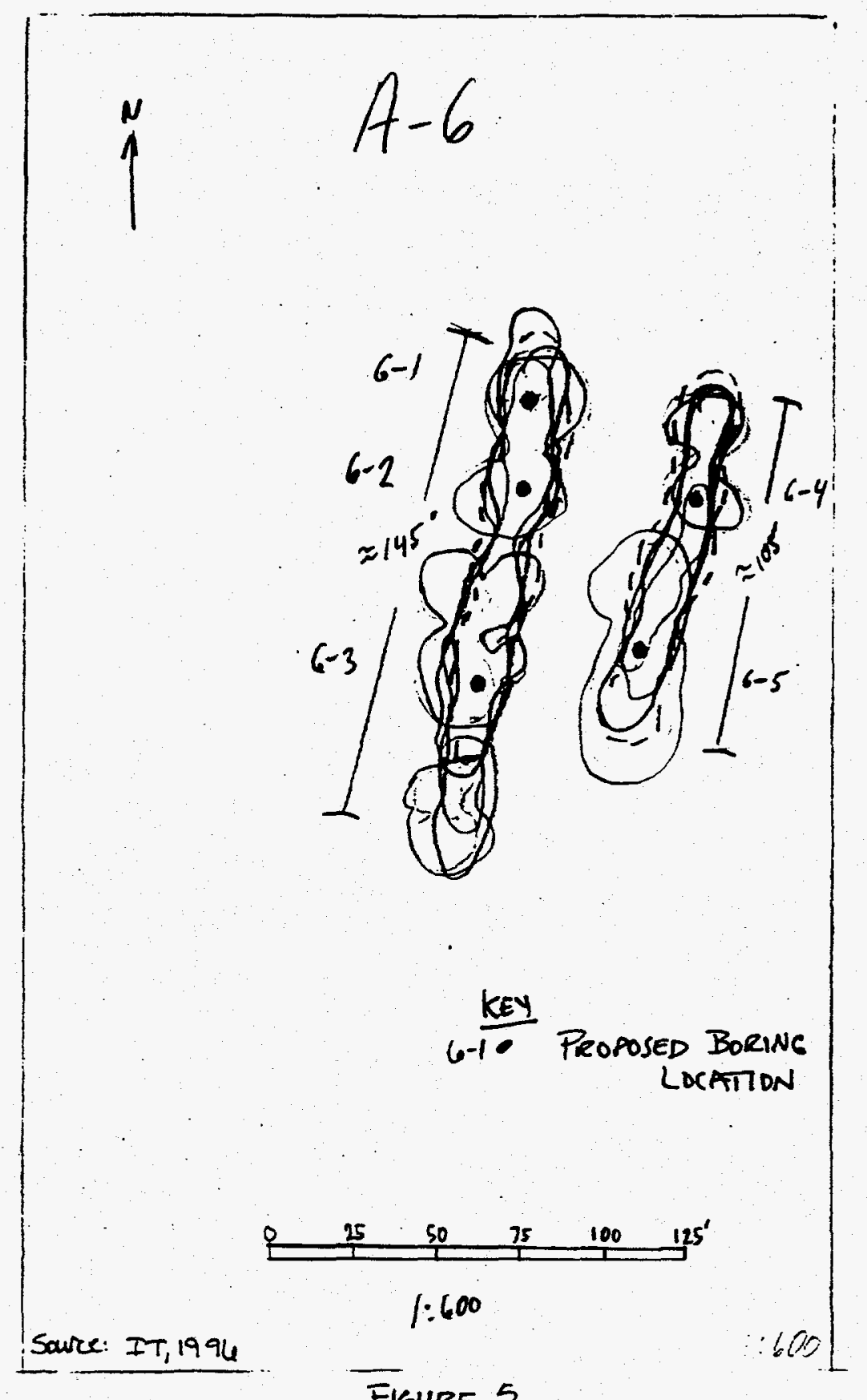

FIGURE 5

Proposed Born g LocatioNs

area 3 Landfill cell A3-6 
Figure 6

Proposed Boring Locations, Area 3 Landfill Cell A3-7

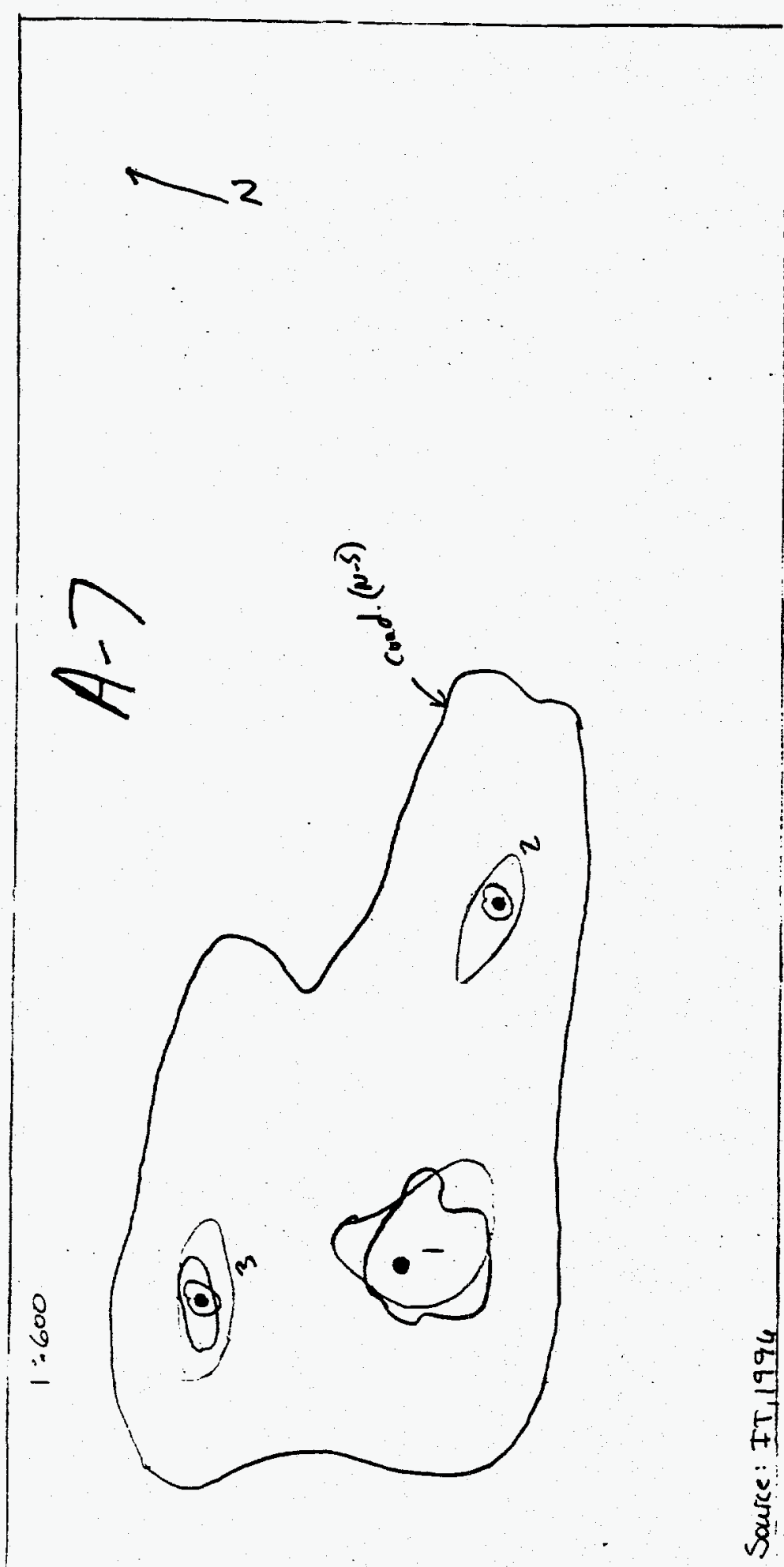

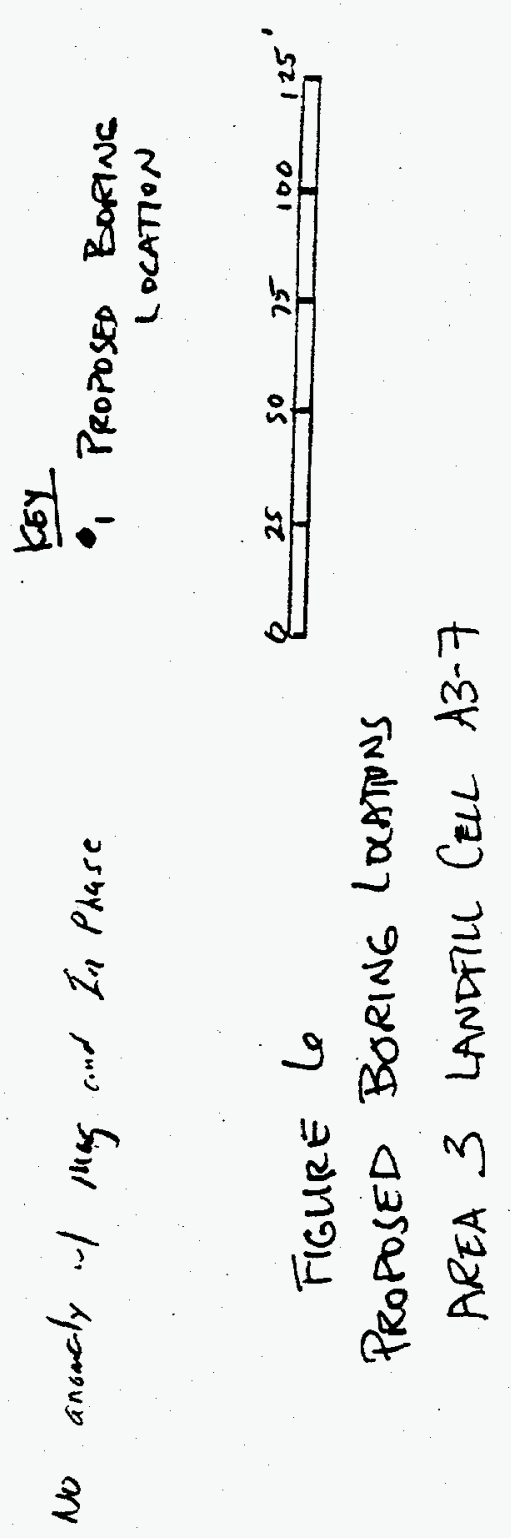




\section{DATA QUALITY OBJECTIVES WORKSHEETS}

Figure 7

Proposed Boring Locations, Area 3 Landfill Cell A3-8

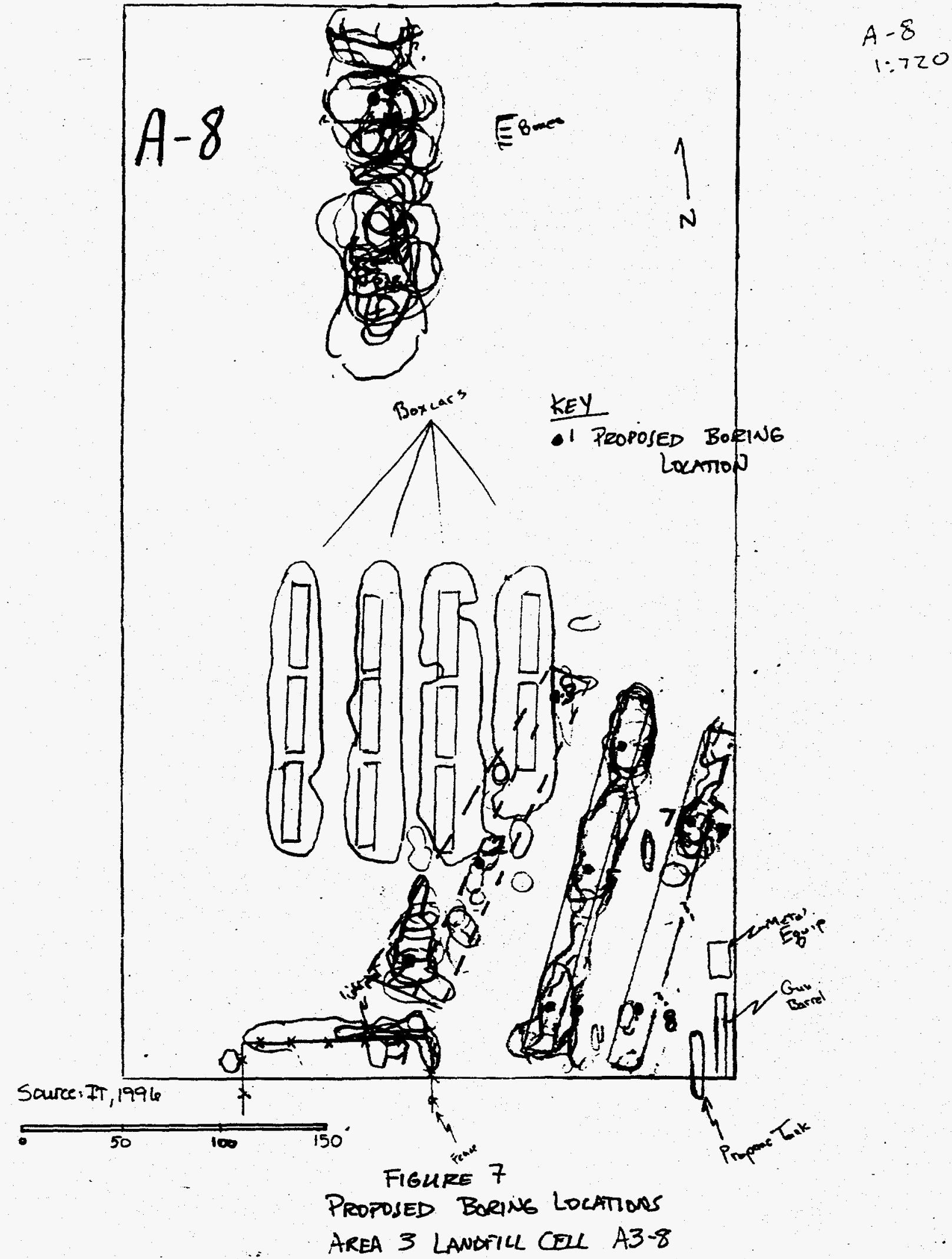




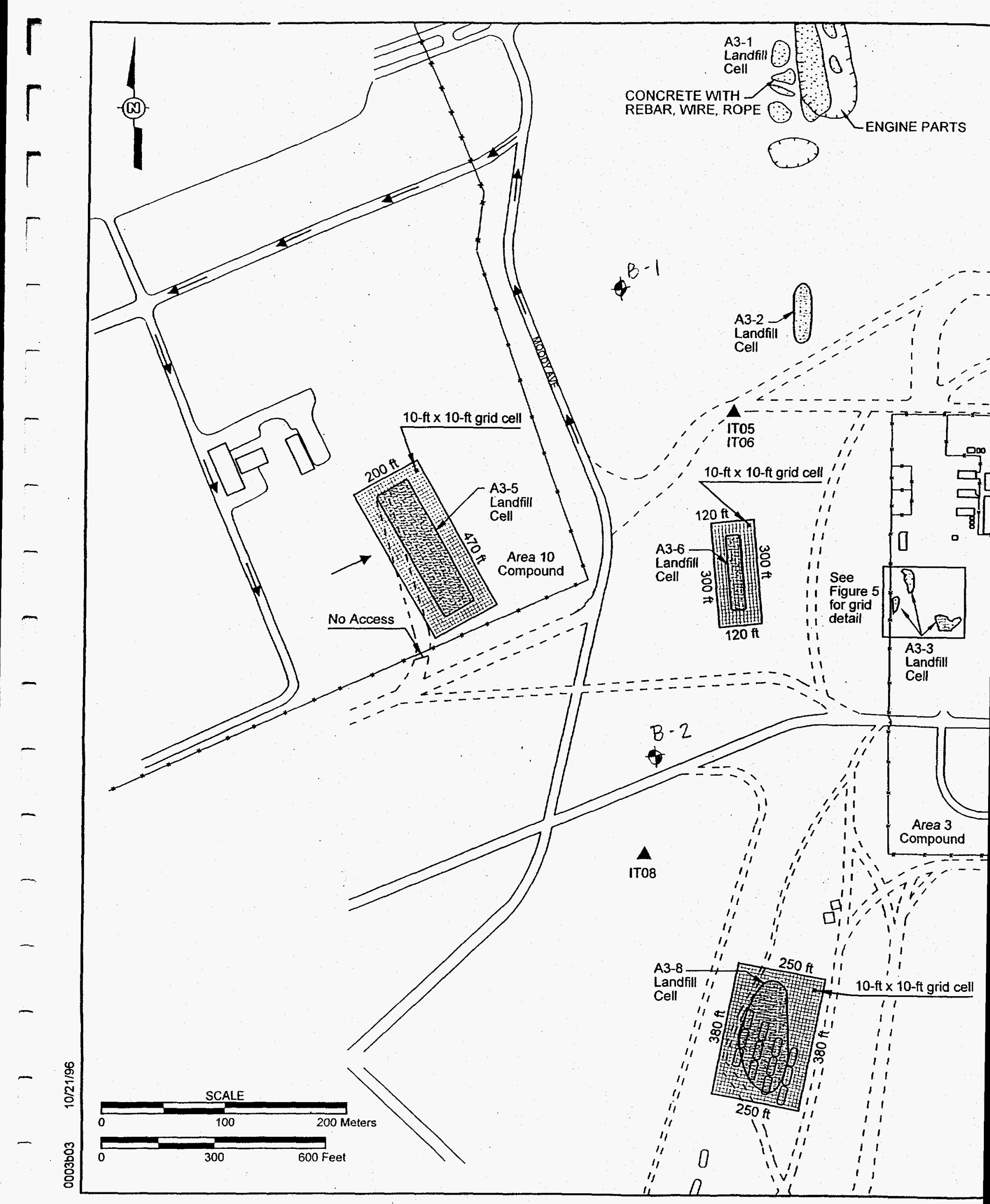




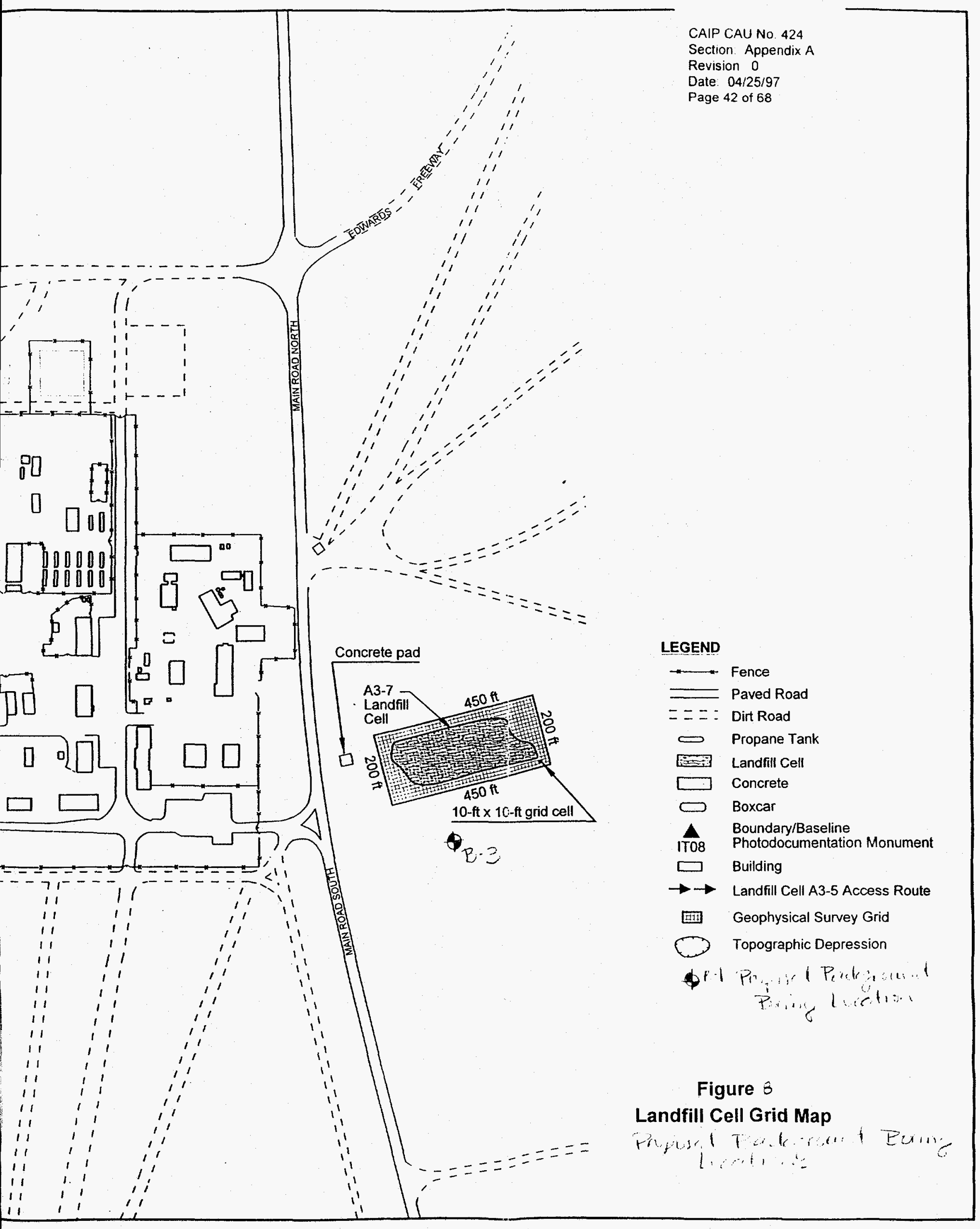




\section{ATTACHMENTS}




\section{ATTACHMENT A}

\section{Area 3 Landfill, Historical Aerial Photos}


DATA QUALITY OBJECTIVES WORKSHEETS

\section{Attachment A}

\section{Area 3 Landfill Historical Aerial Photos}

\begin{tabular}{|c|c|}
\hline Aerial Photo Number & Year Flown \\
\hline \hline ITLV 5489, 5490 & Pre-1962 \\
\hline ITLV 5488 & 1962 \\
\hline EG\&G 3310 - 20 & 1980 \\
\hline EG\&G 4107 - 4 & 1982 \\
\hline EG\&G 5065-17 & 1985 \\
\hline EG\&G 5438 - 52, 5376-47 & 1986 \\
\hline EG\&G 5957-23 & 1988 \\
\hline EG\&G 7523-14 & 1993 \\
\hline
\end{tabular}

References:

EG\&G - Photos from EG\&G archives, Las Vegas, NV (number indicates the perf. and frame number).

ITLV - Photos from IT Corporation Library, Las Vegas, NV (number indicates the library reference number). 
Page 46 of 68

\section{ATTACHMENT B}

\section{Map of Landfill Cells}




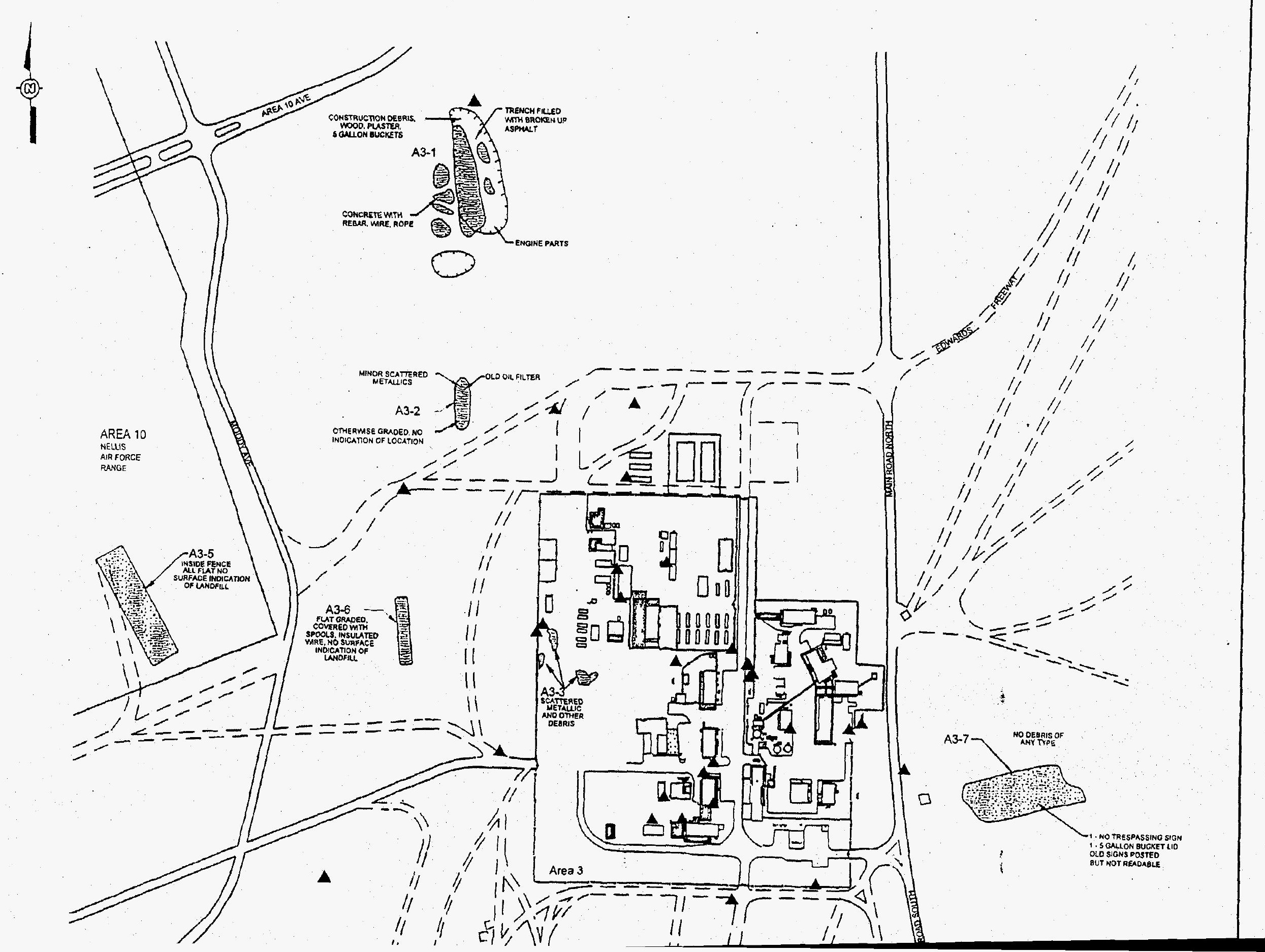




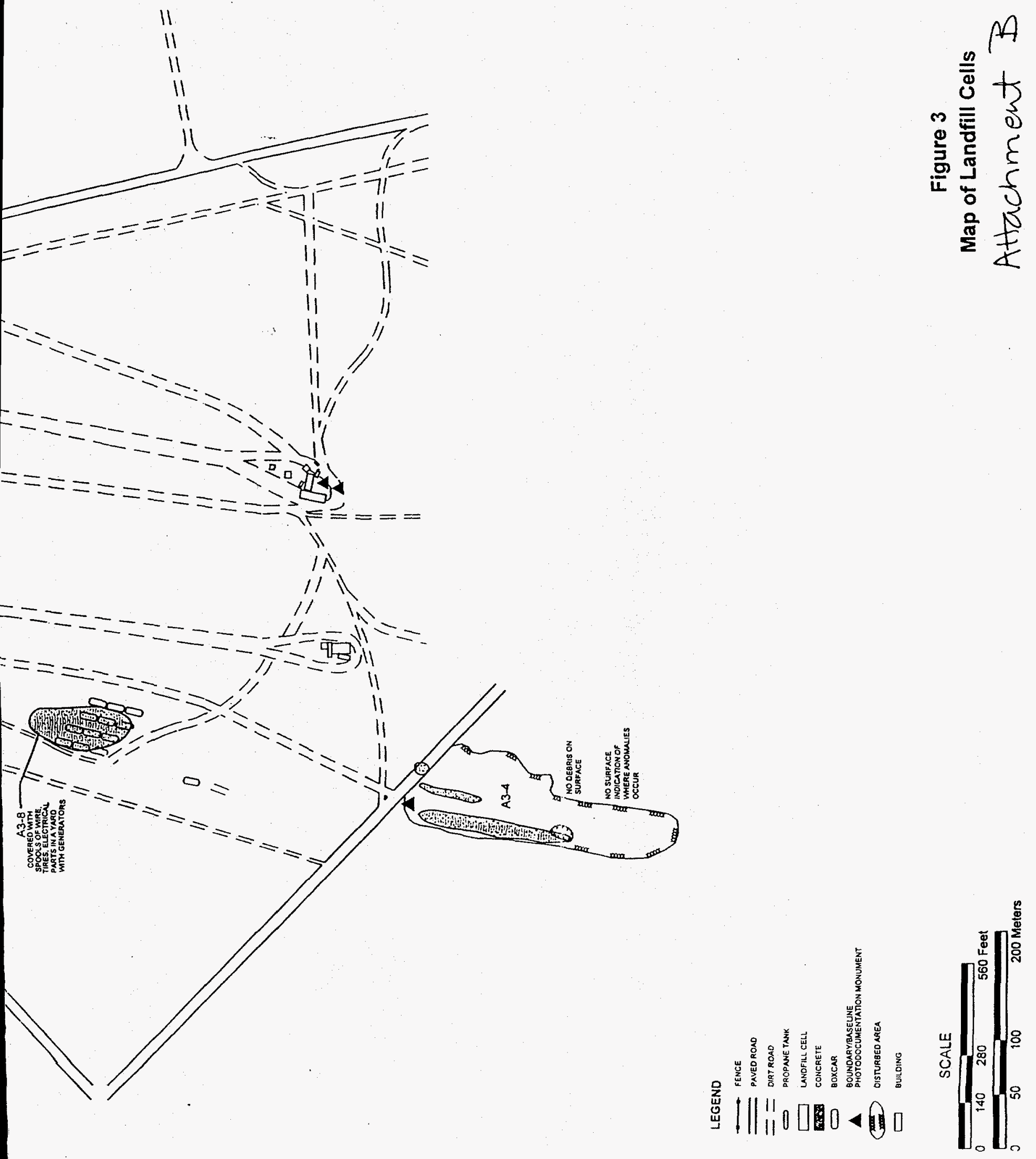




\section{ATTACHMENT C}

\section{Area 3 Landfill Timeline}




\section{Attachment C}

Area 3 Landfill Timeline

Page 49 of 68

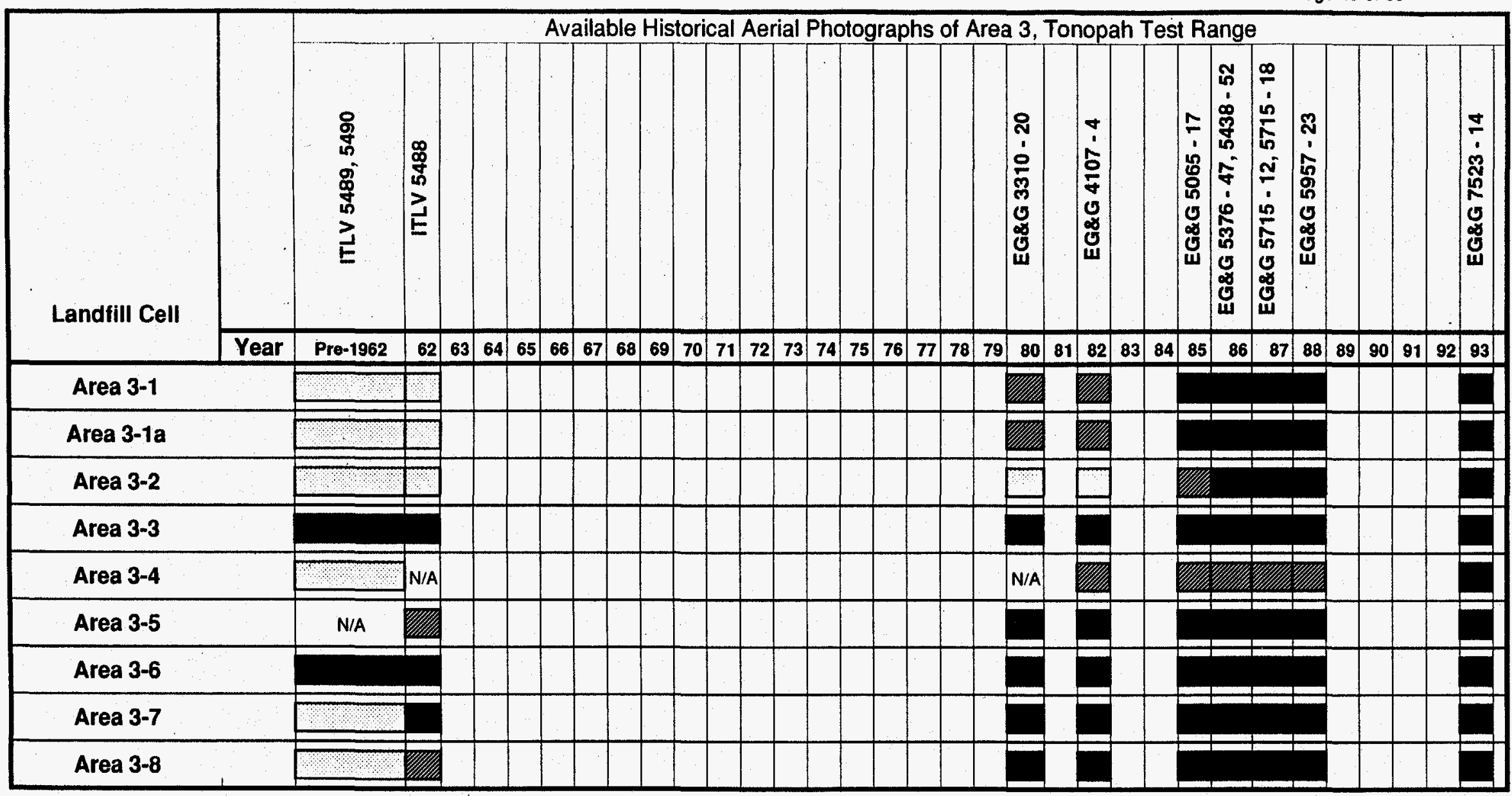

EXPLANATION:

$\mathrm{N} / \mathrm{A}=$ Cell not observable on photo.

Cell open on photo.

$=$ Cell closed on photo.

$\square=$ Cell not excavated at this time

\section{REFERENCES:}

EG\&G= Photos from EG\&G archives, Las Vegas, NV (number indicates perforation and frame)

ITLV = Photos from IT Corporation Library, Las Vegas, NV (number indicates library reference number) 


\section{ATTACHMENT D \\ Chemical, Biological, and Radiological Hazards at Building Structures Inspected at Sandia National Laboratories, Tonopah Test Range}

(This document has been reprinted as it was received in the ITLV office) 


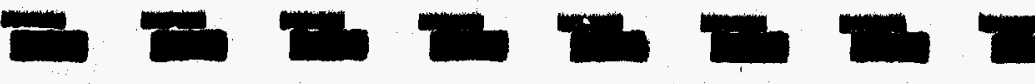 \\ DATA QUALITY OBJECTIVES WORKSHEETS}

Table 2

Chemical, Biological, and Radiological Hazards at Building Structures Inspected at Sandia National Laboratories/Tonopah Test Range
CAIP CAU No. 424

Section: Appendix A

Revision: 0

Date: $04 / 25 / 97$

Page 51 of 68

\begin{tabular}{|c|c|c|c|c|c|c|c|c|c|c|c|}
\hline \multirow{2}{*}{$\begin{array}{l}\text { Building } \\
\text { No. }\end{array}$} & \multirow[b]{2}{*}{ Building Name } & \multirow[b]{2}{*}{$\mathrm{PHA}^{\mathrm{a}}$} & \multirow[b]{2}{*}{$\mathrm{Cl} \cdot 93^{\mathrm{b}}$} & \multirow{2}{*}{$\begin{array}{l}\text { Asbestos } \\
\text { Materials }\end{array}$} & \multicolumn{2}{|c|}{ Chemicals Used ${ }^{d}$} & \multicolumn{2}{|c|}{$\begin{array}{l}\text { Chemicals Documented in Past } \\
\text { Inspections }\end{array}$} & \multirow{2}{*}{$\begin{array}{l}\text { Stained } \\
\text { Area }\end{array}$} & \multirow{2}{*}{$\begin{array}{l}\text { Radioactive } \\
\text { Materials }^{k}\end{array}$} & \multirow{2}{*}{$\begin{array}{c}\text { Other' } \\
\text { Materials }\end{array}$} \\
\hline & & & & & Type ${ }^{\theta}$ & Qty! & Type & Qty. & & & \\
\hline $02-00$ & Askania tower & & & Unknown & & & & & & & \\
\hline $02-01$ & ME-16 shelter & $Y$ & & & & & & & & & \\
\hline $02-50$ & Intrusion lab & $Y$ & $Y$ & $\begin{array}{l}\text { Ceiling, floor } \\
\text { tiles, roof }\end{array}$ & $\begin{array}{c}\text { Oil/grease, } \\
\text { paint, solvents }\end{array}$ & $<1$ qt. & $\begin{array}{c}\text { Oil/grease, } \\
\text { solvents } \\
\text { Nitrogen }\end{array}$ & $\begin{array}{l}2 \text { gals. } \\
250 \mathrm{cf} \text {. }\end{array}$ & & & AST/UST \\
\hline $03-00$ & Antenna tower & $Y$ & & & & & \begin{tabular}{|c|} 
Corrosives, \\
oil/grease, solvents \\
Solder \\
Helium
\end{tabular} & $\begin{array}{c}2 \text { gals. } \\
2 \text { lbs } \\
2 \text { bottles }\end{array}$ & & & \\
\hline $03-02$ & $\begin{array}{l}\text { Carpenter shop } \\
\text { storage }\end{array}$ & & & & & & & & & & \\
\hline $03-03$ & $\begin{array}{l}\text { Telescope parts } \\
\text { storage }\end{array}$ & & & & & & & & & & \\
\hline $03-04$ & $\begin{array}{l}\text { Telescope parts } \\
\text { storage }\end{array}$ & . & & & $\begin{array}{c}\text { Oil/grease, } \\
\text { paint, solvents }\end{array}$ & $<1 \mathrm{qt}$. & & & & & \\
\hline 03-05 & Cable shop storage & & & & & & & & & & \\
\hline $03-06$ & $\begin{array}{l}\text { Plumbing supply } \\
\text { storage }\end{array}$ & & 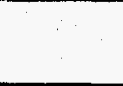 & Floor tiles & & & & & & & \\
\hline $03-07$ & $\begin{array}{l}\text { Plumbing supply } \\
\text { storage }\end{array}$ & & $\bar{Y}$ & & Oil/grease & 15 gals. & Oil/grease & 4 gals. & Oil/grease & & \\
\hline $03-08$ & Open pipe shed & & $Y$ & & $\begin{array}{l}\text { Cleaning } \\
\text { acids, } \\
\text { oil/grease }\end{array}$ & 30 gals. & $\begin{array}{c}\text { Corrosives, } \\
\text { oil/grease, } \\
\text { solvents } \\
\end{array}$ & 50 gals. & Oil/grease & & AST/UST \\
\hline 03-09 & Open storage shed & & & & & & & & & & \\
\hline $03-10$ & $\begin{array}{l}\text { Paint supplies } \\
\text { storage }\end{array}$ & & $\bar{Y}$ & Tiles in storage & $\begin{array}{c}\text { Oil/grease, } \\
\text { paint, solvents }\end{array}$ & $>55$ gals. & Paints, solvents & $>55$ gals. & & & \\
\hline $03-11$ & $\begin{array}{l}\text { Paint supplies } \\
\text { storage }\end{array}$ & & $Y$ & & Paint, solvents & $>55$ gals. & Paints, solvents & $>55$ gals. & $\begin{array}{c}\text { Not } \\
\text { identifiable }\end{array}$ & & \\
\hline
\end{tabular}

Source : IT, 1994

Fiefer to foolnotes at end of table. 
Table 2 (Continued)

Page 52 of 68

Chemical, Biological, and Radiological Hazards at Building Structures Inspected at Sandia National Laboratories/Tonopah Test Range

\begin{tabular}{|c|c|c|c|c|c|c|c|c|c|c|c|}
\hline \multirow{2}{*}{$\begin{array}{l}\text { Building } \\
\text { No. }\end{array}$} & \multirow[b]{2}{*}{ Building Name } & \multirow[b]{2}{*}{$\mathrm{PHA}^{\mathrm{a}}$} & \multirow[b]{2}{*}{$\mathrm{Cl} ' 93^{\mathrm{b}}$} & \multirow{2}{*}{$\begin{array}{l}\text { Asbestos }^{c} \\
\text { Materials }\end{array}$} & \multicolumn{2}{|c|}{ Chemicals Used ${ }^{d}$} & \multicolumn{2}{|c|}{$\begin{array}{c}\text { Chemicals Documented in Past } \\
\text { Inspections }\end{array}$} & \multirow{2}{*}{$\begin{array}{l}\text { Stained } \\
\text { Areal }\end{array}$} & \multirow{2}{*}{$\begin{array}{c}\text { Radioactive } \\
\text { Materialsk }^{k}\end{array}$} & \multirow{2}{*}{$\begin{array}{c}\text { Other' } \\
\text { Materials }\end{array}$} \\
\hline & & & & & Type ${ }^{\circ}$ & Qty! & Type $e^{h}$ & Qty! & & & \\
\hline $03-12$ & $\begin{array}{l}\text { Steam cleaner } \\
\text { storage }\end{array}$ & & & Wall & Gasoline & 5 gals. & & & & & ASTNUST \\
\hline $03-13$ & $\begin{array}{l}\text { Steam cleaner } \\
\text { storage }\end{array}$ & & & & & & & . & & & \\
\hline $03-14$ & Radio shop storage & $\mathbf{Y}$ & $Y$ & & & & $\begin{array}{l}\text { Adhesives/ } \\
\text { sealants }\end{array}$ & $73 \mathrm{lbs}$ & & & \\
\hline 03-15 & $\begin{array}{l}\text { Radio shop supply } \\
\text { storage }\end{array}$ & $Y$ & & & & & & & & & \\
\hline $03-16$ & Ice machine shelter & $Y$ & & Wall & & & & & & & \\
\hline 03.17 & $\begin{array}{l}\text { Electrical parts } \\
\text { storage }^{\mathrm{m}}\end{array}$ & & & Roof & & & & & & & $\cdot$ \\
\hline $03-18$ & AS! storage shed & $Y$ & & Wall & & & & & & & \\
\hline $03-20$ & $\begin{array}{l}\text { Weapons } \\
\text { maintanance facility }\end{array}$ & $\bar{Y}$ & $\mathrm{Y}$ & Floor tiles & & & $\begin{array}{c}\text { Adhesives/ } \\
\text { sealants; } \\
\text { oil/grease, } \\
\text { solvents }\end{array}$ & 5 gals. & & & \\
\hline $03-21$ & $\begin{array}{l}\text { Electrical parts/rope } \\
\text { storage }\end{array}$ & & & & & & & & & & \\
\hline $03-22$ & $\begin{array}{l}\text { Electrical parts } \\
\text { storage }\end{array}$ & & & & & & . & & & & \\
\hline $03-23$ & $\begin{array}{l}\text { Electrical parts } \\
\text { storage }\end{array}$ & & & Floor tiles & & & & & & & \\
\hline $03-24$ & Battery storage & & & - & & & & & $\begin{array}{c}\text { Not } \\
\text { identifiable }\end{array}$ & & \\
\hline $03-25$ & H.D. parts storage & & & Wall & & & & & $\begin{array}{c}\text { Not } \\
\text { identifiable }\end{array}$ & & \\
\hline
\end{tabular}


Table 2 (Continued)

Chemical, Biological, and Radiological Hazards at Building Structures Inspected at Sandia National Laboratories/Tonopah Test Range
CAIP CAU No. 424

Section: Appendix A

Revision: 0

Date: $04 / 25 / 97$

Page 53 of 68

\begin{tabular}{|c|c|c|c|c|c|c|c|c|c|c|c|}
\hline \multirow{2}{*}{$\begin{array}{c}\text { Building } \\
\text { No. }\end{array}$} & \multirow[b]{2}{*}{ Building Name } & \multirow[b]{2}{*}{$\mathrm{PHA}^{\mathrm{a}}$} & \multirow[b]{2}{*}{$\mathrm{Cl} \cdot 93^{b}$} & \multirow{2}{*}{$\begin{array}{l}\text { Asbestos } \\
\text { Materials }\end{array}$} & \multicolumn{2}{|c|}{ Chemicals Used } & \multicolumn{2}{|c|}{$\begin{array}{l}\text { Chemicals Documented in Past } \\
\text { Inspections } 9\end{array}$} & \multirow{2}{*}{$\begin{array}{c}\text { Stained } \\
\text { Area }\end{array}$} & \multirow{2}{*}{$\begin{array}{c}\text { Radioactive } \\
\text { Materials }\end{array}$} & \multirow{2}{*}{$\begin{array}{c}\text { Other' } \\
\text { Materials }\end{array}$} \\
\hline & & & & & Type & Qty! & Type ${ }^{h}$ & Qty. & & & \\
\hline $03-26$ & H.D. parts storage & . & & & & & & & $\begin{array}{c}\text { Not } \\
\text { identifiable } \\
\end{array}$ & & \\
\hline $03-27$ & Battery storage & & & & & & & & & . & \\
\hline 03.28 & CP guard house & $Y$ & $\bar{r}$ & $\begin{array}{l}\text { Ceiling, floor } \\
\text { tiles, roof, wall }\end{array}$ & & & & & & & \\
\hline 03.29 & Generator storage & & . & Floor tiles & & & & & & & \\
\hline $03-30$ & Kitchen storage & $Y$ & & & & & Nitrogen & $250 \mathrm{cf}$. & & & \\
\hline $03-31$ & Water tower & & . & & & & & & & & \\
\hline $03-32$ & Water tank & & & & & & & & & & \\
\hline $03-33$ & Water tank & & & & & & & & & & \\
\hline 03.34 & Pump house & $Y$ & $Y$ & & Propane & $>55$ gals. & Gasoline & $>55$ gals & & & $\begin{array}{l}\text { ASTNUST, } \\
\text { Transformer }\end{array}$ \\
\hline $03-36 \mathrm{C}$ & $\begin{array}{l}\text { Iron worker's } \\
\text { storage }\end{array}$ & & & Floor tiles & & & & & & & \\
\hline 03-36D & $\begin{array}{l}\text { Iron worker's } \\
\text { storage }\end{array}$ & & & & & & & & & & lead bricks \\
\hline $03-36 R$ & Storage shed & & & & $\begin{array}{l}\text { Cleaning } \\
\text { supplies }\end{array}$ & $<1 \mathrm{qt}$. & & & & & \\
\hline $03-37$ & Kitchen storage & & & & & & & & Oil/grease & & \\
\hline 03-39 & Oil storage & & & & & & & & & & Batteries \\
\hline $03-40$ & Bulk shredder & $Y$ & & & & & & & & & \\
\hline 03.41 & $\begin{array}{l}\text { Facility storage } \\
\text { shed }\end{array}$ & . & $Y$ & $\begin{array}{l}\text { Floor tiles, } \\
\text { ventilation } \\
\text { system }\end{array}$ & & & Starting fluid & $>55$ gals & . & & \\
\hline
\end{tabular}


Table 2 (Continued)

Chemical, Biological, and Radiological Hazards at Building Structures Inspected at

\section{Sandia National Laboratories/Tonopah Test Range}

\begin{tabular}{|c|c|c|c|c|c|c|c|c|c|c|c|}
\hline \multirow{2}{*}{$\begin{array}{c}\text { Building } \\
\text { No. }\end{array}$} & \multirow[b]{2}{*}{ Building Name } & \multirow[b]{2}{*}{$\mathrm{PHA}^{\mathrm{a}}$} & \multirow[b]{2}{*}{$\mathrm{Cl} \cdot 93^{b}$} & \multirow{2}{*}{$\begin{array}{l}\text { Asbestos } \\
\text { Materials } \\
\end{array}$} & \multicolumn{2}{|c|}{ Chemicals Used } & \multicolumn{2}{|c|}{$\begin{array}{c}\text { Chemicals Documented in Past } \\
\text { Inspections }\end{array}$} & \multirow{2}{*}{$\begin{array}{c}\text { Stained } \\
\text { Areal }\end{array}$} & \multirow{2}{*}{$\begin{array}{l}\text { Radioactive } \\
\text { Materials }\end{array}$} & \multirow{2}{*}{$\begin{array}{c}\text { Other' } \\
\text { Materials }\end{array}$} \\
\hline & & & & & Type ${ }^{\circ}$ & Qty.' & Type & Qty. & & & \\
\hline $03-42$ & Flammable storage & & $Y$ & & $\begin{array}{l}\text { Oil/grease, } \\
\text { solvents }\end{array}$ & 20 gals. & $\begin{array}{l}\text { Oi/grease, } \\
\text { propane, } \\
\text { solvents }\end{array}$ & 50 gals. & & & \\
\hline $03-43$ & $\begin{array}{l}\text { Fiber termination } \\
\text { building }\end{array}$ & & & Floor tiles, wall & & & & & & & \\
\hline $03-44 B$ & Wood storage & & $Y$ & & $\begin{array}{c}\text { Cement, ice } \\
\text { melt, solvents }\end{array}$ & $4,500 \mathrm{lbs}$. & $\begin{array}{c}\text { Cement, ice melt, } \\
\text { oil/grease }\end{array}$ & $>5000 \mathrm{lbs}$ & & & $\begin{array}{l}\text { Vermin } \\
\text { waste }\end{array}$ \\
\hline 03-44D & Storage & & $Y$ & & & & $\begin{array}{l}\text { Oil/grease, paint, } \\
\text { solvents }\end{array}$ & 2 lbs. & Oil/grease & & \\
\hline 03-50 & Kitchens and labs & $Y$ & $Y$ & $\begin{array}{l}\text { Ceiling, floor } \\
\text { tiles, roof, wall }\end{array}$ & $\begin{array}{c}\text { Cleaning } \\
\text { supplies, } \\
\text { insecticides, } \\
\text { oil/grease, } \\
\text { solder, } \\
\text { solvents } \\
\end{array}$ & 30 gals. & $\begin{array}{c}\text { Insecticides, } \\
\text { oil/grease, solvents } \\
\text { Solder }\end{array}$ & $\begin{array}{c}>55 \text { gals. } \\
1 \mathrm{lb} .\end{array}$ & & & \\
\hline 03.51 & $\begin{array}{l}\text { Administration } \\
\text { building }\end{array}$ & $Y$ & & $\begin{array}{c}\text { Ceiling, } \\
\text { communication } \\
\text { center, floor } \\
\text { tiles, roof } \\
\end{array}$ & & & & & & $\begin{array}{l}\text { U-238 } \\
\text { check } \\
\text { source }\end{array}$ & Batteries \\
\hline $03-52$ & Stockroom and labs & $Y$ & $Y$ & $\begin{array}{l}\text { Ceiling, floor } \\
\text { tile, pipe } \\
\text { insulation } \\
\end{array}$ & $\begin{array}{c}\text { Cleaning } \\
\text { supplies, paint, } \\
\text { solvents }\end{array}$ & 30 gals. & $\begin{array}{l}\text { Oil/grease, paint, } \\
\text { propane, solvents }\end{array}$ & 5 gals & & & \\
\hline $03-53$ & Generator building & & $Y$ & $\begin{array}{l}\text { Coiling, floor } \\
\text { tiles, walls, } \\
\text { pipe } \\
\text { insultation, } \\
\text { fittings }\end{array}$ & $\begin{array}{l}\text { Cleaning } \\
\text { supplies, fire } \\
\text { retardants, } \\
\text { diesel }\end{array}$ & $>55$ gals. & $\begin{array}{l}\text { Cleaning supplies, } \\
\text { corrosives, diesel, } \\
\text { oil/grease, solvents }\end{array}$ & $>55$ gals. & Oil/grease & & $\begin{array}{l}\text { Generator, } \\
\text { Transformer }\end{array}$ \\
\hline $03-54$ & $\begin{array}{l}\text { Equipment } \\
\text { maintenance, } \\
\text { machine shop }\end{array}$ & $Y$ & $Y$ & $\begin{array}{l}\text { Ceiling, floor } \\
\text { tiles, debris }\end{array}$ & $\begin{array}{l}\text { Oil/grease, } \\
\text { solvents }\end{array}$ & 11 gals. & Oil/grease, paints & 11 gals. & & & Compressor \\
\hline
\end{tabular}


Table 2 (Continued)

Revision: 0

Date: $04 / 25 / 97$

Chemical, Biological, and Radiological Hazards at Building Structures Inspected at Page 55 of 68 Sandia National Laboratories/Tonopah Test Range

\begin{tabular}{|c|c|c|c|c|c|c|c|c|c|c|c|}
\hline \multirow{2}{*}{$\begin{array}{l}\text { Building } \\
\text { No. }\end{array}$} & \multirow[b]{2}{*}{ Building Name } & \multirow[b]{2}{*}{$P H A^{a}$} & \multirow[b]{2}{*}{$\mathrm{Cl} \cdot 93^{b}$} & \multirow{2}{*}{$\begin{array}{l}\text { Asbestos } \\
\text { Materials }\end{array}$} & \multicolumn{2}{|c|}{ Chemicals Used $^{d}$} & \multicolumn{2}{|c|}{$\begin{array}{c}\text { Chemicals Documented in Past } \\
\text { Inspections }\end{array}$} & \multirow{2}{*}{$\begin{array}{c}\text { Stained } \\
\text { Area }\end{array}$} & \multirow{2}{*}{$\begin{array}{l}\text { Radioactive } \\
\text { Materials }^{k}\end{array}$} & \multirow{2}{*}{$\begin{array}{l}\text { Other' } \\
\text { Materials }\end{array}$} \\
\hline & & & & & Type ${ }^{\circ}$ & Qty.! & Type ${ }^{h}$ & Qty. & & & \\
\hline $03-55$ & Photo shop & $Y$ & $Y$ & $\begin{array}{l}\text { Ceiling, floor, } \\
\text { tiles, fittings }\end{array}$ & $\begin{array}{l}\text { Corrosives, } \\
\text { solvents, } \\
\text { paints }\end{array}$ & 20 gals. & $\begin{array}{c}\text { Cleaning supplies, } \\
\text { corrosives, } \\
\text { oilgrease, } \\
\text { paint, solvents } \\
\end{array}$ & $>25$ gals. & & & Transiormer \\
\hline $03-56$ & Telescope shop & $Y$ & $Y$ & Ceiling & $\begin{array}{l}\text { Oil/grease, } \\
\text { solvents }\end{array}$ & 2 gals. & $\begin{array}{c}\text { Cleaning supplies, } \\
\text { oil/grease, paint, } \\
\text { solvents, } \\
\text { Solder }\end{array}$ & $\begin{array}{l}2 \text { gals. } \\
1 \mathrm{lb} .\end{array}$ & & & \\
\hline $03-57$ & $\begin{array}{l}\text { Operations, control } \\
\text { building }\end{array}$ & $Y$ & $Y$ & $\begin{array}{l}\text { Ceiling, floor } \\
\text { tiles, computer } \\
\text { jack }\end{array}$ & $\begin{array}{c}\text { Cleaning } \\
\text { supplies, } \\
\text { compressed } \\
\text { gas, oil/grease, } \\
\text { solvents, } \\
\text { solder } \\
\end{array}$ & 2 gals. & $\begin{array}{c}\text { Adhesives/ } \\
\text { sealants, cleaning } \\
\text { supplies, } \\
\text { oilgrease, solvents } \\
\text { Helium }\end{array}$ & $\begin{array}{l}4 \text { gals. } \\
426 \mathrm{cf}\end{array}$ & & & \\
\hline $03-58$ & UPS facility & $Y$ & $Y$ & Roof & Diesel & $>55$ gais. & Diesel & $>55$ gals. & & & $\begin{array}{c}\text { Generator, } \\
\text { oily rags, } \\
\text { transiormer }\end{array}$ \\
\hline $03-60$ & $\begin{array}{l}\text { Automotive } \\
\text { maintenance }\end{array}$ & $Y$ & $Y$ & $\begin{array}{c}\text { Ceiling, floor, } \\
\text { wall }\end{array}$ & $\begin{array}{c}\text { Oil/grease, } \\
\text { solvents } \\
\end{array}$ & 3 gals. & $\begin{array}{l}\text { Cleaning supplies, } \\
\text { oil/grease, solvents }\end{array}$ & 4 gals. & Oil/grease & & \\
\hline $03-61$ & Tire shop & $Y$ & $Y$ & & & & & & Oil/grease & & $\begin{array}{l}\text { Vermin } \\
\text { waste }\end{array}$ \\
\hline $03-62$ & $\begin{array}{l}\text { Welding, sheet } \\
\text { metal shop }\end{array}$ & $Y$ & Y & & $\begin{array}{l}\text { Oil/grease } \\
\text { corrosives }\end{array}$ & & $\begin{array}{l}\text { Cleaning supplies, } \\
\text { oil/grease, solvents }\end{array}$ & 4 gals. & & & \\
\hline $03-63$ & Generator shop & & $Y$ & $\begin{array}{l}\text { Ceiling, floor } \\
\text { tiles, wall }\end{array}$ & & & $\begin{array}{c}\text { Adhesives/ } \\
\text { sealants, cleaning } \\
\text { supplies, solvents } \\
\end{array}$ & 1.5 gals & & & \\
\hline $03-64$ & Microwave building & & & $\begin{array}{c}\text { Ceiling, } \\
\text { hangers, roof }\end{array}$ & & & & & & & \\
\hline
\end{tabular}


Table 2 (Continued)

Chemical, Biological, and Radiological Hazards at Building Structures Inspected at Page 56 of 68 Sandia National Laboratories/Tonopah Test Range

\begin{tabular}{|c|c|c|c|c|c|c|c|c|c|c|c|}
\hline \multirow{2}{*}{$\begin{array}{c}\text { Building } \\
\text { No. } \\
\end{array}$} & \multirow[b]{2}{*}{ Builuling Name } & \multirow[b]{2}{*}{$\mathrm{PHA}^{\mathrm{a}}$} & \multirow[b]{2}{*}{$\mathrm{Cl} \cdot 93^{\mathrm{b}}$} & \multirow{2}{*}{$\begin{array}{l}\text { Asbestos }^{c} \\
\text { Materials } \\
\end{array}$} & \multicolumn{2}{|c|}{ Chemicals Used ${ }^{d}$} & \multicolumn{2}{|c|}{$\begin{array}{c}\text { Chemicals Documented in Past } \\
\text { Inspections }\end{array}$} & \multirow{2}{*}{$\begin{array}{c}\text { Stained } \\
\text { Area }^{i} \\
\end{array}$} & \multirow{2}{*}{$\begin{array}{l}\text { Radioactive } \\
\text { Materials }^{\mathrm{k}}\end{array}$} & \multirow{2}{*}{$\begin{array}{c}\text { Other' } \\
\text { Materials } \\
\end{array}$} \\
\hline & & & & & Type ${ }^{\circ}$ & Qty. & Type ${ }^{h}$ & Qty. & & & \\
\hline $03-65$ & Padio shop & $\mathbf{Y}$ & $\mathbf{Y}$ & $\begin{array}{c}\text { Ceiling, debris, } \\
\text { floor tiles, } \\
\text { ducting } \\
\text { insulation, } \\
\text { fittings, root, } \\
\text { ventilation } \\
\text { system }\end{array}$ & $\begin{array}{l}\text { Solder, } \\
\text { solvents, } \\
\text { corrosives }\end{array}$ & 2 q1s. & $\begin{array}{l}\text { Corrosives, } \\
\text { oil/grease, solvents }\end{array}$ & 0.5 gals & Oil/grease & & Batteries \\
\hline 03.66 & $\begin{array}{l}\text { Electrical } \\
\text { maintenance }\end{array}$ & $Y$ & & & Oil/grease & $<1$ qt. & $\begin{array}{c}\text { Cleaning supplies, } \\
\text { oil/grease }\end{array}$ & 2 qts. & & & Transformer \\
\hline $03-67$ & $\begin{array}{l}\text { Electrical and } \\
\text { REECo }\end{array}$ & $Y$ & Y & $\begin{array}{l}\text { Ceiling, floor } \\
\text { tiles, fittings, } \\
\text { pipo insulation, } \\
\text { ventilation } \\
\text { system, wall } \\
\end{array}$ & $\begin{array}{l}\text { Oil/grease, } \\
\text { solvents }\end{array}$ & 5 gals. & $\begin{array}{l}\text { Cleaning supplies, } \\
\text { oil/grease, paint, } \\
\text { solvents }\end{array}$ & 13 gals. & $\begin{array}{l}\text { Oil/grease, } \\
\text { mineral/rust }\end{array}$ & & \\
\hline $03-68$ & $\begin{array}{l}\text { Telephone } \\
\text { equipment shelter }\end{array}$ & $\gamma$ & & Floor tile & $\begin{array}{c}\text { Compressed } \\
\text { gas, oil/grease, } \\
\text { solvents, } \\
\text { Solder } \\
\end{array}$ & 4 gals. & $\begin{array}{c}\text { Adhesives/sealant, } \\
\text { oilvgrease, solvent } \\
\text { solder }\end{array}$ & $\begin{array}{l}3 \text { gals. } \\
2 \text { lbs. }\end{array}$ & & & Batteries \\
\hline $03-69$ & $\begin{array}{l}\text { Security, first aid, } \\
\text { fire }\end{array}$ & $Y$ & $Y$ & $\begin{array}{l}\text { Ceiling, floor } \\
\text { tiles }\end{array}$ & $\begin{array}{l}\text { Compressed } \\
\text { gas, paint }\end{array}$ & $>55$ 'gals. & $\begin{array}{l}\text { Cleaning supplies, } \\
\text { diesel, fire ext. } \\
\text { agents, oil/grease, } \\
\text { oxidizers, propane, } \\
\text { solvents }\end{array}$ & $>55$ gals. & & & Batteries \\
\hline 03-70T & REECo lunchroom & & $\mathrm{Y}$ & Floor tiles & $\begin{array}{l}\text { Cleaning } \\
\text { supplies }\end{array}$ & $<1 \mathrm{qt}$. & Cleaning supplies & 6 gals. & & & \\
\hline $03-71$ & Cable storage & & & & $\begin{array}{l}\text { Solvents, } \\
\text { activated } \\
\text { carbon, } \\
\text { corrosives }\end{array}$ & $>55$ gals. & & & & & \\
\hline
\end{tabular}


Table 2 (Continued)

Chemical, Biological, and Radiological Hazards at Building Structures Inspected at Sandia National Laboratorles/Tonopah Test Range
CAIP CAU No. 424

Section: Appendix A

Revision: 0

Date: $04 / 25 / 97$

Page 57 of 68

\begin{tabular}{|c|c|c|c|c|c|c|c|c|c|c|c|}
\hline \multirow{2}{*}{$\begin{array}{c}\text { Building } \\
\text { No. }\end{array}$} & \multirow[b]{2}{*}{ Building Name } & \multirow[b]{2}{*}{$\mathrm{PHA}^{\mathrm{a}}$} & \multirow[b]{2}{*}{$\mathrm{Cl} \cdot 93^{b}$} & \multirow{2}{*}{$\begin{array}{l}\text { Asbestos } \\
\text { Materials }\end{array}$} & \multicolumn{2}{|c|}{ Chemicals Used ${ }^{d}$} & \multicolumn{2}{|c|}{$\begin{array}{c}\text { Chemicals Documented in Past } \\
\text { Inspections }\end{array}$} & \multirow{2}{*}{$\begin{array}{c}\text { Stained } \\
\text { Areal }\end{array}$} & \multirow{2}{*}{$\begin{array}{l}\text { Radioactive } \\
\text { Materials }^{k}\end{array}$} & \multirow{2}{*}{$\begin{array}{c}\text { Other' } \\
\text { Materials }\end{array}$} \\
\hline & & & & & Type ${ }^{\theta}$ & Qty! & Type ${ }^{h}$ & Qty. ${ }^{i}$ & & & \\
\hline $03-73$ & $\begin{array}{l}\text { Paint, carpenter, } \\
\text { plumbing }\end{array}$ & $\bar{Y}$ & $\bar{Y}$ & $\begin{array}{l}\text { Ceiling, floor } \\
\text { tiles, fittings, } \\
\text { wall }\end{array}$ & $\begin{array}{l}\text { Explosives, } \\
\text { compressed } \\
\text { gas, paint, } \\
\text { solvents }\end{array}$ & $>55$ gals. & $\begin{array}{c}\text { Cleaning supplies, } \\
\text { paint, propane, } \\
\text { solvents }\end{array}$ & $>55$ gals. & Oil/grease & & \\
\hline $03-74$ & H.D. repair shop & $\mathrm{Y}$ & $\mathrm{Y}$ & $\begin{array}{l}\text { Floor tiles, } \\
\text { ventilation } \\
\text { system }\end{array}$ & $\begin{array}{c}\text { Compressed } \\
\text { gas, oil/grease, } \\
\text { solvents, paint }\end{array}$ & $>55$ gals. & $\begin{array}{l}\text { Cleaning supplies, } \\
\text { corrosives, } \\
\text { oil/grease, paint, } \\
\text { solvents } \\
\text { Acetylene, oxygen }\end{array}$ & $\begin{array}{l}>55 \text { gals. } \\
2,300 \mathrm{lbs}\end{array}$ & Oil/grease & & \\
\hline $03-75$ & $\begin{array}{l}\text { Shipping and } \\
\text { receiving }\end{array}$ & & $Y$ & Floor tile & $\begin{array}{l}\text { Compressed } \\
\text { gas, paint, } \\
\text { solvents, } \\
\text { corrosives }\end{array}$ & 4 gals. & $\begin{array}{c}\text { Copier supplies, } \\
\text { ink, oil/grease, } \\
\text { paint } \\
\text { Acetylene, argon, } \\
\text { carbon-dioxide, } \\
\text { oxygen, propane } \\
\end{array}$ & $\begin{array}{l}>55 \text { gals. } \\
19,000 \mathrm{cf} .\end{array}$ & Isocyanate & $\begin{array}{l}\text { Cesium-137 } \\
\text { and Cobali- } \\
60 \text { source, } \\
\text { tritium }^{n}\end{array}$ & \\
\hline $03-76$ & Pilot's lounge & & & Floor tiles, roof & $\begin{array}{l}\text { Cleaning } \\
\text { supplies, oil/ } \\
\text { grease }\end{array}$ & $<1$ qt. & . & & & & \\
\hline $03-77$ & Telemetry storage & $Y$ & & Floor tiles & & & Nitrogen & $250 \mathrm{ct}$. & & & \\
\hline $03-78$ & $\begin{array}{l}\text { ASI storage and } \\
\text { supplies }\end{array}$ & $Y$ & & $\begin{array}{c}\text { Conditions are } \\
\text { unknown }\end{array}$ & $\begin{array}{l}\text { Cleaning } \\
\text { supplies }\end{array}$ & 2 gals. & $\begin{array}{l}\text { Cleaning supplies, } \\
\text { oil/grease, paint }\end{array}$ & 5 gals. & & & \\
\hline $03-79$ & ASI exercise & & $\mathrm{Y}$ & $\begin{array}{l}\text { Floor tiles, } \\
\text { ventilation } \\
\text { system }\end{array}$ & $\begin{array}{l}\text { Cleaning } \\
\text { supplies }\end{array}$ & 3 gals. & Cleaning supplies & 2 gals. & & & \\
\hline $03-80$ & $\begin{array}{l}\text { Vehicle service } \\
\text { facility }\end{array}$ & & $\bar{Y}$ & $\begin{array}{l}\text { Ceiling, floor } \\
\text { tiles, wall }\end{array}$ & Oil/grease & $>55$ gals. & $\begin{array}{c}\text { Antifreeze, } \\
\text { cleaning supplies, } \\
\text { oil/grease, solvents }\end{array}$ & $>55$ gals & Oil/grease & & AST/UST \\
\hline $03-81 T$ & $\begin{array}{l}\text { Purchasing, } \\
\text { lectinical security }\end{array}$ & $\bar{Y}$ & $Y$ & $\begin{array}{l}\text { Ceiling, floor } \\
\text { tiles }\end{array}$ & & & Solvents & $<1 \mathrm{qt}$. & & & \\
\hline
\end{tabular}


Table 2 (Continued)

Chemical, Biological, and Radiological Hazards at Bullding Structures Inspected at Sandia National Laboratorles/Tonopah Test Range
Date: $04 / 25 / 97$

Page 58 of 68

\begin{tabular}{|c|c|c|c|c|c|c|c|c|c|c|c|}
\hline \multirow{2}{*}{$\begin{array}{c}\text { Building } \\
\text { No. }\end{array}$} & \multirow[b]{2}{*}{ Building Name } & \multirow[b]{2}{*}{$\mathrm{PHA}^{\mathbf{a}}$} & \multirow[b]{2}{*}{$\mathrm{Cl} \cdot 93^{\mathrm{b}}$} & \multirow{2}{*}{$\begin{array}{l}\text { Asbestos } \\
\text { Materials }\end{array}$} & \multicolumn{2}{|c|}{ Chemicals Used } & \multicolumn{2}{|c|}{$\begin{array}{l}\text { Chemicals Documented in Past } \\
\text { Inspections }\end{array}$} & \multirow{2}{*}{$\begin{array}{c}\text { Stained } \\
\text { Areal }\end{array}$} & \multirow{2}{*}{$\begin{array}{l}\text { Radioactive } \\
\text { Materialsk }^{k}\end{array}$} & \multirow{2}{*}{$\begin{array}{c}\text { Other } \\
\text { Materials }\end{array}$} \\
\hline & & & & & Type ${ }^{\circ}$ & Qty.' & Type ${ }^{h}$ & Qty. & & & \\
\hline $03-82 T$ & Drafting & $Y$ & $\bar{Y}$ & Floor tiles & $\begin{array}{l}\text { Compressed } \\
\text { gas }\end{array}$ & $<1 \mathrm{qt}$. & Solvents & $<1 \mathrm{qt}$. & & & \\
\hline 03-83T & Auto parts storage & & $Y$ & & $\begin{array}{c}\text { Compressed } \\
\text { gas, oil/grease, } \\
\text { solvent, paint }\end{array}$ & 12 gals. & $\begin{array}{c}\text { Cleaning supplies, } \\
\text { oil/grease, paint, } \\
\text { propane }\end{array}$ & 5 gals. & $\begin{array}{c}\text { Not } \\
\text { identifiable }\end{array}$ & & \\
\hline $03-84 T$ & Drafting storage & & & & $\begin{array}{c}\text { Oil/grease, } \\
\text { solvents, paint }\end{array}$ & 1 gal. & & & & & \\
\hline $03-85 \mathrm{~T}$ & $\begin{array}{l}\text { Fire equipment } \\
\text { storage }\end{array}$ & & & & & & & & & & \\
\hline $03-87$ & $\begin{array}{l}\text { Drum containment } \\
\text { facility }\end{array}$ & & $Y$ & & $\begin{array}{l}\text { Oil/grease, } \\
\text { solvents }\end{array}$ & $>55$ gals. & $\begin{array}{c}\text { Antifreeze, diesel, } \\
\text { oil/grease, solvents }\end{array}$ & $>55$ gals & & & \\
\hline 03-88 & Electrical storage & $\therefore$ & & & & & & & & & \\
\hline $03-89$ & Freezer locker & & & & & & & & & & \\
\hline $03-90$ & Freezer locker & & & & & & & & & & \\
\hline $03-91$ & Boiler equipment & & & Pipe insulation & & & & & & & \\
\hline $09-01$ & $\begin{array}{l}\text { ASI practice AMO } \\
\text { storage }\end{array}$ & & & & & & & & & & \\
\hline $09-02$ & Storage (unused) & & & & & & & & & & \\
\hline $09-03$ & $\begin{array}{l}\text { Power supply/Zener } \\
\text { lights }\end{array}$ & & & & & & & & & & \\
\hline $09-04$ & Camera tower & & & & & & & & & & \\
\hline $09-05$ & Area 9 storage & & & & & & & & & & \\
\hline $09-06$ & Storage sholter & & & & & & & & Solvent & Unknown $^{n}$ & \\
\hline $09-12$ & $\begin{array}{l}\text { Antenna power } \\
\text { shelter }\end{array}$ & & & & & & & & & & \\
\hline
\end{tabular}


Table 2 (Continued)

\title{
Chemical, Blological, and Radiological Hazards at Building Structures Inspected at Sandla National Laboratories/Tonopah Test Range
}

\author{
a PHA = Preliminary hazard assessment performed in the building/facility/site (SNL/NM, 1993b; SNL/NM, 1992c; SNL/NM, 1990). Codes: $Y=$ PHA performed. \\ ${ }^{b}$ Chemical Inventory = Chemical inventory performed in 1993 (SNLNM, 1994b). Codes: $Y=$ inventory performed. \\ CAsbestos suspected to be present: Refor to asbestos survey report (BCM, 1992) for more information. \\ ${ }^{d}$ Chemicals = chemicals that are currently present in the buildingfiacility/site (August, 1994). \\ Type = type or description of chemicals present during inspection in August 1994. \\ 'Quantity - Quantity of chemicals present during inspection conducted in August 1994. This quantity represents an estimaled total volume of all chemicals present. \\ OChemicals present during past preliminary hazard assessments or chemical inventories (SNL/NM, 1993b; SNL/NM 1992c; SNL/NM, 1990; SNL/NM, 1994b). \\ ${ }^{h}$ Type = type or description of chemical present during past assessments or inventories. \\ 'Quantity - estimated maximum amount of chemicals present during past inspections. \\ Stains - Stains, discoloration, or evidence of past spill(s) in an area found during building inspection in August 1994 \\ Radioactivity = Radioactive materials that have been or are currently present in the buildingfacility/site (SNL/NM, 1994d; SNL/NM 1993b; SNL/NM, 1992c; SNL/NM; 1990). \\ 'Other = Any other materials identified during the inspection of the building/facility/site in August 1994 that may pose a risk to personnel or environment. \\ mBuilding removed or destroyed prior to inspection. \\ ${ }^{n}$ Radiological survey was pertormed in August 1994. \\ 'Radiological survey performed by SNL/Tonopah (SNL/NM, 1994d). \\ Punable to access building. Exterior inspection only. \\ ASTNST = aboveground storage tank/underground storage tank1-25 \\ ct = cubic feet \\ qt. = quart \\ gals. = gallons \\ lbs. - pounds \\ oz ounces \\ SNM = Special nuclear materials.
}

Source: JT, 1994 


\section{ATTACHMENT E}

\section{Tonopah Test Range, Area 3, Building Year Built Report}

(This document has been reprinted as it was received in the ITLV office) 


\section{TONOPAH TEST RANGE \\ AREA 3 \\ BUILDING YEAR BUILT REPORT \\ (Revised 5-NOV-92}

BLDG. NO. DESCRIPTION

03-00

$03-02$

03-03

03-04

03-05

03-06

03-07

03-08

03-09

03-10

03-11

03-12

03-13

03-14

03-15

03-16

03-17

03-18

03-19

03-20

03-21

03-22

03-23

03-24

03-25

03-26

03-27

03-28

03-29

03-30

03-31

03-32

03-33

03-34

03-35A

03-35B

$03-35 \mathrm{C}$

03-35D

03-35E

WATER TANK

WATER TANK

PUMP HOUSE
ANTENNA TOWER

CARPENTER SHOP STORAGE

TELESCOPE SHOP STORAGE

TELESCOPE SHOP STORAGE

CABLE SHOP STORAGE

PLUMBING SUPPLY STORAGE

PLUMBING SUPPLY STORAGE

OPEN PIPE SHED

OPEN STORAGE SHED

PAINT SUPPLY STORAGE

PAINT SUPPLY STORAGE

STEAM CLEANER SHED

STEAM CLEANER SHED

RADIO SHOP STORAGE

RADIO SHOP STORAGE

ICE MACHINE SHED

ELECTRICAL PARTS STORAGE

ASI STORAGE SHED

WEAPON CLEANING FACILITY

WEAPON MAINTENANCE FACILITY

ELECTRICAL PARTS STORAGE

ELECTRICAL PARTS STORAGE

ELECTRICAL PARTS STORAGE

BATTERY STORAGE

H.D. PARTS STORAGE

H.D. PARTS STORAGE

BATTERY STORAGE

CP GUARD HOUSE

GENERATOR STORAGE

MICROWAVE STORAGE

WATER TOWER

AUTO PARTS STORAGE

WATER BOTTLE STORAGE

DRILL/OPR. STORAGE

PROPERTY SALVAGE STORAGE

RADIO SHOP STORAGE
YEAR BUILT

1980

1962

1962

1962

1962

1962

1962

1962

1988

1962

1962

1962

1962

1962

1968

1962

1968

1962

1962

1962

1962

1962

1962

1962

1962

1962

1962

1980

1962

1962

1965

1962

1962

1964

1932

1932

1932

1932

1932

Page 1 of 3

Sources SNL, 1992. 
TONOPAH TEST RANGE AREA 3

BUILDING YEAR BUILT REPORT

\begin{tabular}{|c|c|c|}
\hline DG. NO. & DESCRIPTION & EAR BUILT \\
\hline $03-35 F$ & OPTICAL TRACKING STORAGE & 1932 \\
\hline $03-35 G$ & L. DUTY TIRE STOEAGE & 1932 \\
\hline $03-35 \mathrm{H}$ & ASI SPARE PARTS/GUN BOX & 1932 \\
\hline $03-35 \mathrm{~J}$ & TECHNICAL SECURITY STORAGE & 1932 \\
\hline $03-35 K$ & ELECTRONIC STORAGE & 1932 \\
\hline $03-35 \mathrm{~L}$ & RADAR STORAGE & 1932 \\
\hline $03-35 \mathrm{M}$ & L. DUTY PARTS & 1932 \\
\hline $03-35 \mathrm{~N}$ & TELEMETRY STORAGE & 1932 \\
\hline $03-35 P$ & L. DUTY TIRES & 1932 \\
\hline $03-36 \mathrm{~A}$ & PLUMBING STORAGE & 1932 \\
\hline $03-36 \mathrm{~B}$ & PLUMBING STORAGE & 1932 \\
\hline $8 C$ & IRON WORKERS STORAGE & 1932 \\
\hline $03-3$ & IRON WORKERS STORAGE & 1932 \\
\hline $\mathbf{E}$ & FIRE DEPT. STORAGE & 1932 \\
\hline$-36 \mathrm{~F}$ & ELECTRICAL STORAGE & 1932 \\
\hline $6 \mathrm{G}$ & SHEET METAL STORAGE & 1932 \\
\hline $6 \mathrm{H}$ & STORAGE (McNEIL) & 1932 \\
\hline- & HDUTY/PAINTERS & 1932 \\
\hline $\mathrm{K}$ & CARPENTERS STORAGE & 1932 \\
\hline & ELECTRICAL STORAGE & 1932 \\
\hline$M$ & IRON WORKERS STORAGE & 1932 \\
\hline 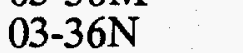 & ELECTRICAL STORAGE & 1932 \\
\hline & STORAGE SHED & 1962 \\
\hline & STORAGE SHED & 1962 \\
\hline 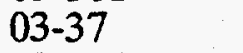 & KITCHEN STORAGE & 1962 \\
\hline & FLUID STORAGE & 1968 \\
\hline & OIL STORAGE & 1968 \\
\hline & BULK SHREDDER & 1990 \\
\hline & FACILITY STORAGE SHED & 1990 \\
\hline 2 & AUTO PARTS STORAGE & 1958 \\
\hline & FIBER TERMINATION BUILDING & 1991 \\
\hline $4 \mathrm{~A}$ & LABORERS STORAGE & 1932 \\
\hline $4 \mathrm{~B}$ & LABORERS STORAGE & 1965 \\
\hline $4 \mathrm{C}$ & LABORERS STORAGE & 1932 \\
\hline $4 \mathrm{D}$ & LABORERS STOEAGE & 1968 \\
\hline 5 & ASBESTOS AASSESSMENT BUILDING & 1992 \\
\hline & LABS, KITCHEN, TEST DIRECTORS & 1956 \\
\hline & ADMINISTRATION BUILDING & 1962 \\
\hline & STOCK ROOM \& LABS & 1961 \\
\hline & GENERATOR BUILDING & 1965 \\
\hline & EQ.MAINT., MACHINE SHOP & 1960 \\
\hline & PHOTO SHOP & 1964 \\
\hline 02 & TELESCOPE SHOP & 1965 \\
\hline
\end{tabular}




\author{
TONOPAH TEST RANGE \\ AREA 3 \\ BUILDING YEAR BUILT REPORT
}

$\begin{array}{llr}\text { BLDG. NO. } & \text { DESCRIPTION } & \text { YEAR BUILT } \\ 03-57 & \text { OPERATION \& CONTROL BLDG. } & 1980 \\ 03-58 & \text { U.P.S. } & 1970 \\ 03-60 & \text { AUTOMOTIVE MAINT. } & 1962 \\ 03-61 & \text { TIRE SHOP } & 1960 \\ 03-62 & \text { WELDING, SHEET METAL SHOP } & 1960 \\ 03-63 & \text { GENERATOR SHOP } & 1960 \\ 03-64 & \text { MICROWAVE BLDG. } & 1971 \\ 03-65 & \text { RADIO SHOP } & 1960 \\ 03-66 & \text { ELECTRICAL MAINTENANCE } & 1960 \\ 03-67 & \text { ELECTRICAL \& REECO } & 1965 \\ 03-68 & \text { TELEPHONE EQUIP. SHELTER } & 1986 \\ 03-69 & \text { SECURITY, FIRST AID \& FIRE DEPT. } & 1966 \\ 03-70 T & \text { REECO LUNCH ROOM } & 1990 \\ 03-71 & \text { FACILITY EQUIP. STORAGE } & 1981 \\ 03-72 & \text { BOILER ROOM \& EQUIP. BLDG. } & 1966 \\ 03-73 & \text { PAINT, CARPENTER, PLUMBING } & 1968 \\ 03-74 & \text { H.D. REPAIR SHOP } & 1983 \\ 03-75 & \text { SHIPPING \& RECEIVING } & 1980 \\ 03-76 & \text { PILOTS LOUNGE } & 1964 \\ 03-77 & \text { TELEMETRY STORAGE } & 1981 \\ 03-78 & \text { ASI STORAGE } & 1981 \\ 03-79 & \text { ASI EXERCISE FACILITY } & 1981 \\ 03-80 & \text { VEHICLE SERVICE FACILITY } & 1991 \\ 03-81 T & \text { PURCHASING, TECH SECURITY } & 1989 \\ 03-82 T & \text { DRAFTING } & 1989 \\ 03-83 T & \text { AUTO PARTS STORAGE } & 1989 \\ 03-84 T & \text { DRAFTING STORAGE } & 1989 \\ 03-85 T & \text { FIRE EQUIPMENT STORAGE } & 1989 \\ 03-87 & \text { DRUM CONTAINMENT FACILITY } & 1991 \\ 03-88 & \text { ELECTRICAL STORAGE } & 1991 \\ & & \end{array}$

Page 3 of 3

Source: SNL, 1992 


\section{ATTACHMENT F}

FY 97 Industrial Sites Schedule CAU 424 - Area 3 Landfill 


\section{DATA QUALITY OBJECTIVES WORKSHEETS}

ATTACAMSANT F

Y 97 Industrial Sites Schedul

CAIT CAUTNu. 424

Section: Appendix A Revision 2

Date: $04 / 25 / 97$

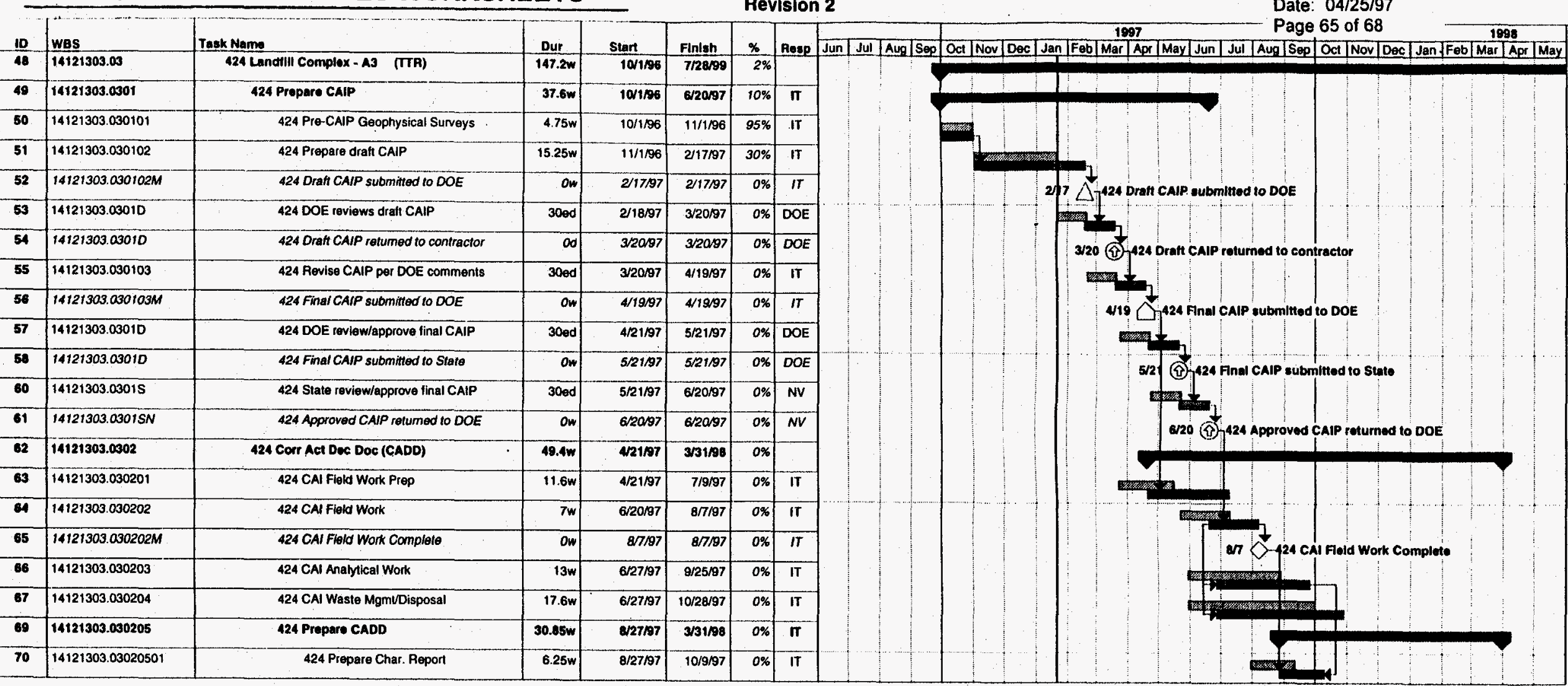

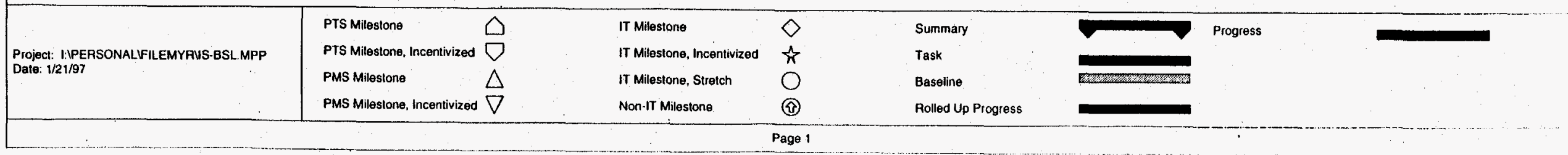




\section{ATTACHMENT G}

\section{Drilling/Investigation Options for Area 3 Landfill Complex}




\begin{tabular}{|c|c|c|c|c|}
\hline DATA SOURCE & EXPLANATION & ADVANTAGES & DISADVANTAGES & TRIGGER POINTS \\
\hline \multicolumn{5}{|l|}{ Preferred Methods: } \\
\hline $\begin{array}{l}\text { Direct vertical penetration } \\
\text { through cell - Sonic Drilling }\end{array}$ & $\begin{array}{l}\text { Locate drillhole } \\
\text { directly above } \\
\text { geophysical anomalies } \\
\text { and drill to total depth }\end{array}$ & $\begin{array}{l}\text { - Provides a vertical } \\
\text { profile of the cell } \\
\text { contents and ensures } \\
\text { representative sampling } \\
\text { below the cell including } \\
\text { vertical extent. } \\
\text { - Cost effective } \\
\text { - Does not require an } \\
\text { accurate delineation of } \\
\text { cell boundaries }\end{array}$ & $\begin{array}{l}\text { - Creates the possibility for } \\
\text { advancing a contaminated } \\
\text { plume } \\
\text { - The potential for refusal limits } \\
\text { the drilling method selection } \\
\text { - H\&S concerns } \\
\text { - Potential for increased IDW }\end{array}$ & $\begin{array}{l}\text { 1. Stop drilling and notify NDEP if encounter } \\
\text { anything not anticipated (i.e., RCRA } \\
\text { constituents, radiological contamination, } \\
\text { free liquid, drums). } \\
\text { 2. Continue drilling upon concurrence from } \\
\text { the core decision team to do so and how to } \\
\text { continue. If free liquid is encountered, one } \\
\text { start-up method may be to move the drilling } \\
\text { location ( } 5 \text { to } 10 \mathrm{ft} \text { ) and continue drilling. } \\
\text { 3. If refusal is met, move to a new location. }\end{array}$ \\
\hline Existing hydrologic data & $\begin{array}{l}\text { Review existing } \\
\text { USGS hydrologic data } \\
\text { from TTR water wells }\end{array}$ & $\begin{array}{l}\text { - Provides data to } \\
\text { determine the } \\
\text { probability of } \\
\text { impacting groundwater } \\
\text { at each cell }\end{array}$ & $\begin{array}{l}\text { - Data is not always complete } \\
\text { and up to date }\end{array}$ & \\
\hline $\begin{array}{l}\text { Additional hydrologic data } \\
\text { for the zone immediately } \\
\text { below the contamination. } \\
\text { Note: NDEP is to be notified } \\
\text { if performed in the field. }\end{array}$ & $\begin{array}{l}\text { Collect in situ soil } \\
\text { samples for } \\
\text { hydrologic/geotech. } \\
\text { analysis }\end{array}$ & $\begin{array}{l}\text { - Provides input for } \\
\text { closure strategies }\end{array}$ & $\begin{array}{l}\text { - Difficult to collect undisturbed, } \\
\text { in situ sample with } \\
\text { conventional drilling methods }\end{array}$ & \\
\hline \multicolumn{5}{|c|}{ Alternate/Additional Methods: } \\
\hline $\begin{array}{l}\text { Angle boring outside of cell. } \\
\text { This is to be performed after } \\
\text { reaching a stop point with } \\
\text { Sonic Drilling. }\end{array}$ & $\begin{array}{l}\text { Position the drill rig } \\
\text { near one side of the } \\
\text { cell (distance } \\
\text { dependent on rig } \\
\text { capability and the } \\
\text { estimated depth of cell } \\
\text { bottom) and drill angle } \\
\text { holes to intersect a } \\
\text { point below the cell } \\
\text { bottom without } \\
\text { intersecting cell } \\
\text { contents }\end{array}$ & $\begin{array}{l}\text { - Avoids problems } \\
\text { associated with direct } \\
\text { cell intrusion (see } \\
\text { above) } \\
\text { - Provides samples of in } \\
\text { situ soil for background } \\
\text { characterization } \\
\text { - Cost effective } \\
\text { - Wide selection of } \\
\text { drilling methods }\end{array}$ & $\begin{array}{l}\text { - Limits the vertical } \\
\text { characterization of the soil } \\
\text { below the cell } \\
\text { - Will not penetrate a significant } \\
\text { section immediately below the } \\
\text { cell bottom } \\
\text { - Cannot directly define the } \\
\text { vertical extent of } \\
\text { contamination } \\
\text { - Dependent on accurate } \\
\text { estimates of cell dimensions }\end{array}$ & $\begin{array}{l}\text { 1. Stop drilling if trench contents are found. } \\
\text { Move drilling location over ( } 5 \text { to } 10 \text { feet) } \\
\text { and continue drilling. } \\
\text { 2. Notify NDEP if encounter anything not } \\
\text { anticipated (i.e., RCRA constituents, } \\
\text { radiological contamination, free liquid, } \\
\text { drums). } \\
\text { 3. Continue drilling upon concurrence from } \\
\text { the core decision team to do so and how to } \\
\text { continue. If free liquid is encountered, one } \\
\text { start-up method may be to move the drilling } \\
\text { location ( } 5 \text { to } 10 \mathrm{ft} \text { ) and continue drilling. } \\
\text { 4. If refusal is met, move to a new location. }\end{array}$ \\
\hline
\end{tabular}




\begin{tabular}{|c|c|c|c|c|}
\hline DATA SOURCE & EXPLANATION & ADVANTAGES & DISADVANTAGES & TRIGGER POINTS \\
\hline \multicolumn{2}{|c|}{ Alternate/Additional Methods cont.: } & & & \\
\hline $\begin{array}{l}\text { Vertical boring adjacent to } \\
\text { cell along with trenches/test } \\
\text { pits along the edge of the cell } \\
\text { to define the cell boundaries. }\end{array}$ & $\begin{array}{l}\text { - Advance a vertical } \\
\text { boring as close to } \\
\text { the edge of the cell } \\
\text { as possible without } \\
\text { intruding the cell. } \\
\text { - Use a backhoe to } \\
\text { scrape ground } \\
\text { surface near the } \\
\text { estimated cell } \\
\text { boundary to } \\
\text { determine the } \\
\text { fill/native soil } \\
\text { contact }\end{array}$ & $\begin{array}{l}\text { - Avoids problems } \\
\text { associated with direct } \\
\text { cell intrusion } \\
\text { - Used to determine cell } \\
\text { dimensions } \\
\text { - Inexpensive. }\end{array}$ & $\begin{array}{l}\text { - Requires an accurate } \\
\text { delineation of cell boundaries } \\
\text { - Does not characterize the area } \\
\text { directly beneath the cell } \\
\text { - Creates extra IDW } \\
\text { - Potential for inadvertent cell } \\
\text { intrusion }\end{array}$ & $\begin{array}{l}\text { 1. Stop drilling if trench contents are found. } \\
\text { Move drilling location over ( } 5 \text { to } 10 \text { feet) } \\
\text { and continue drilling. } \\
\text { 2. Notify NDEP if encounter anything not } \\
\text { anticipated (i.e., RCRA constituents, } \\
\text { radiological contamination, free liquid, } \\
\text { drums). } \\
\text { 3. Continue drilling upon concurrence from } \\
\text { the core decision team to do so and how to } \\
\text { continue. If free liquid is encountered, one } \\
\text { start-up method may be to move the drilling } \\
\text { location ( } 5 \text { to } 10 \mathrm{ft} \text { ) and continue drilling. } \\
\text { 4. If refusal is met, move to a new location. }\end{array}$ \\
\hline Neutron probe monitoring & $\begin{array}{l}\text { Install wells to access } \\
\text { neutron probe for soil } \\
\text { moisture monitoring }\end{array}$ & $\begin{array}{l}\text { - } \text { Monitors a wide area } \\
\text { - Provides an early } \\
\text { warning of leachate } \\
\text { migration }\end{array}$ & $\begin{array}{l}\text { Does not characterize } \\
\text { constituents (moisture content } \\
\text { only) }\end{array}$ & \\
\hline Passive soil gas survey & $\begin{array}{l}\text { Usually placed on or } \\
\text { just below the surface } \\
\text { to measure flux }\end{array}$ & $\begin{array}{l}\text { Able to detect very } \\
\text { low levels of volatile } \\
\text { organics } \\
\text { - Inexpensive }\end{array}$ & - Limited to VOCs & \\
\hline Active soil gas survey & $\begin{array}{l}\text { Install monitoring } \\
\text { points at or near the } \\
\text { landfill boundaries. } \\
\text { Commonly a direct } \\
\text { push technology }\end{array}$ & $\begin{array}{ll}\text { Able to detect very } \\
\text { low levels of volatile } \\
\text { organics } \\
- & \text { Inexpensive }\end{array}$ & $\begin{array}{ll}\text { - } & \text { Limited to VOCs } \\
\text { - } & \text { Depth limited }\end{array}$ & \\
\hline $\begin{array}{l}\text { Groundwater monitoring } \\
\text { wells }\end{array}$ & $\begin{array}{l}\text { Install groundwater } \\
\text { monitoring wells as } \\
\text { needed }\end{array}$ & $\begin{array}{l}\text { Monitor contaminated } \\
\text { aquifer }\end{array}$ & - Expensive & \\
\hline
\end{tabular}




\section{Appendix B \\ Nevada Environmental Restoration Project Document Review Sheet Nevada Division of Environmental Protection Comments and Responses}




\section{NEVADA ENVIRONMENTAL RESTORATION PROJECT DOCUMENT REVIEW SHEET}

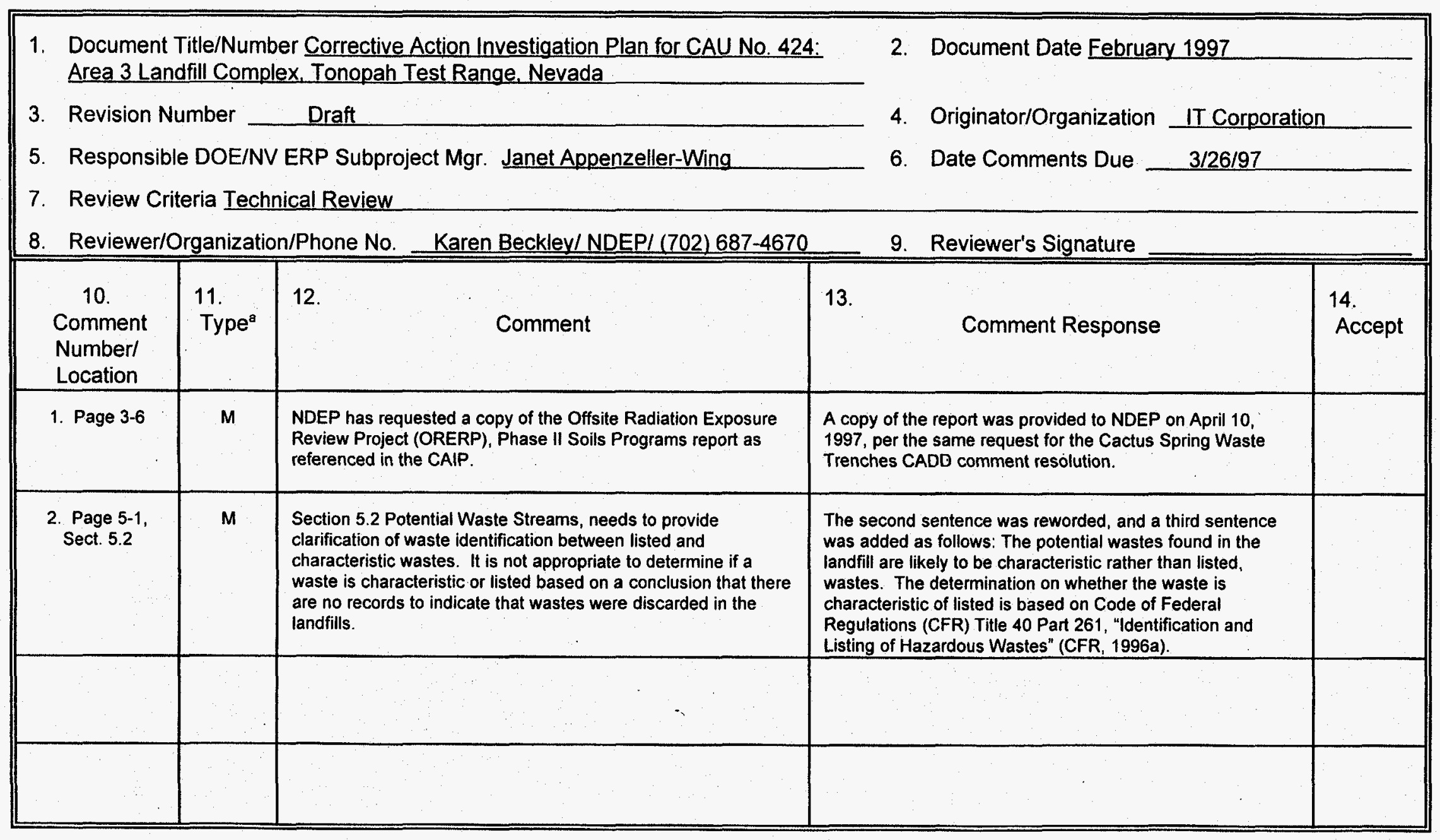


Date: $04 / 25 / 97$

Page 1 of 8

\section{Appendix C}

\section{Geophysical Survey-Result Figures}




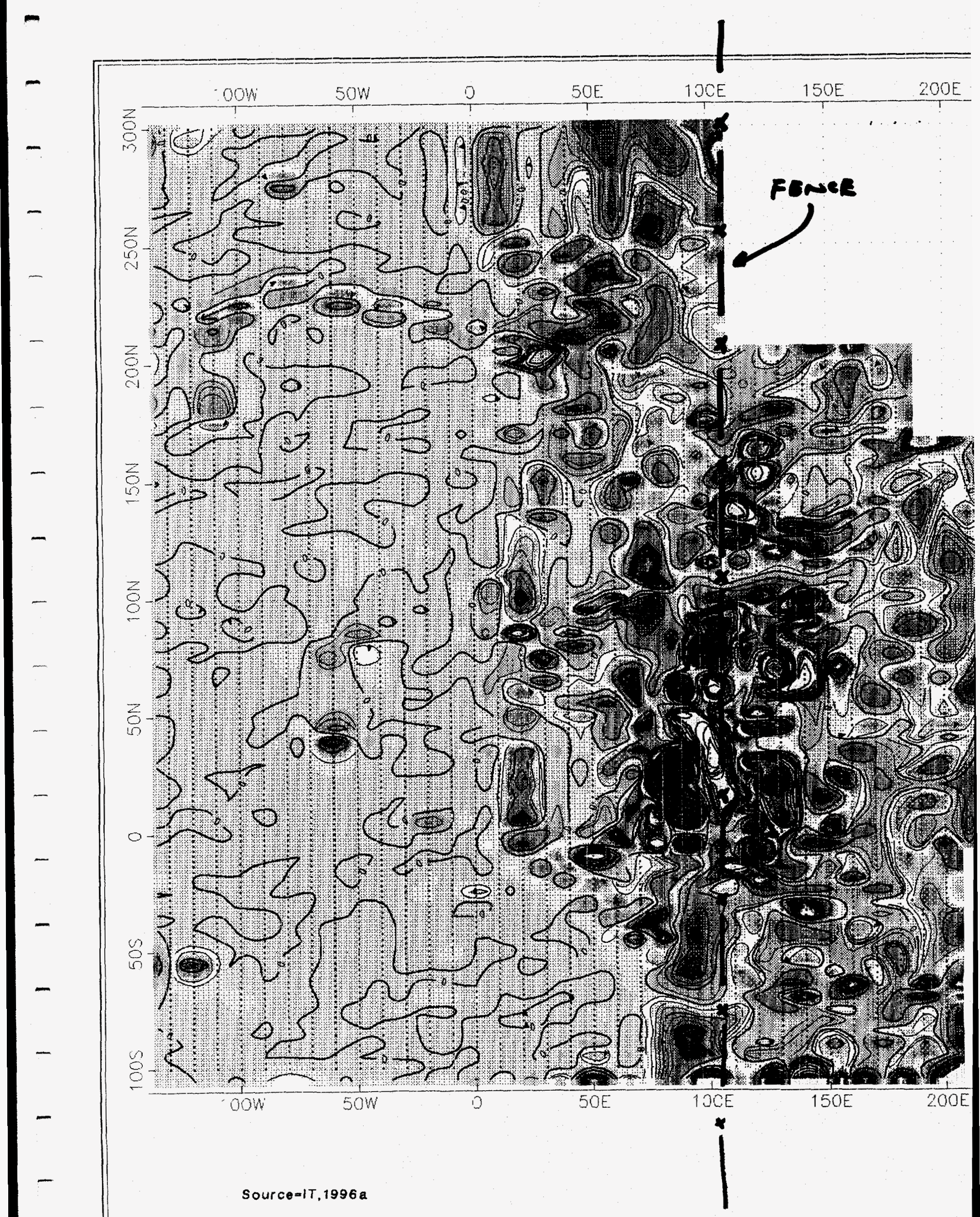


$250 E$

$3 \mathrm{COE}$

$350 \mathrm{E}$
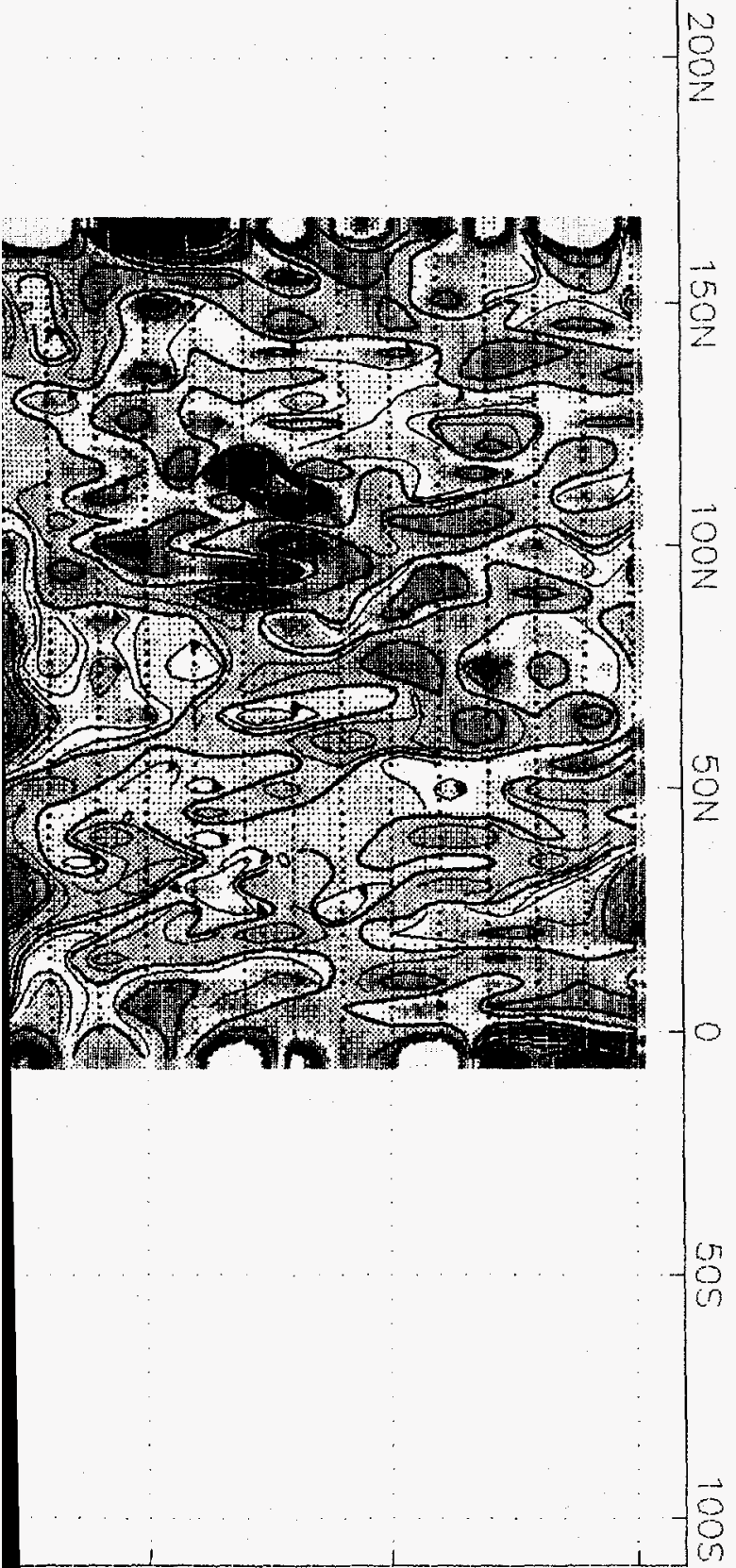

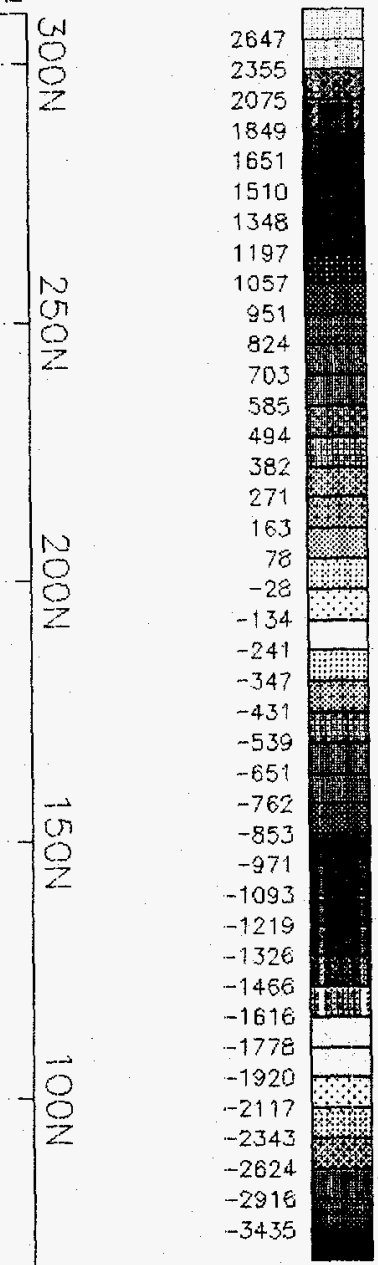

nanoTeslas/meter

Page 2 of 8

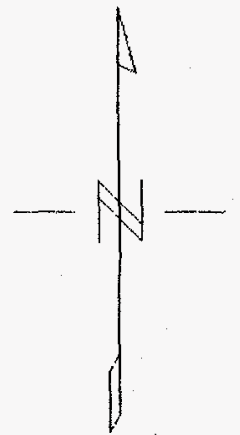

Scale 1:600

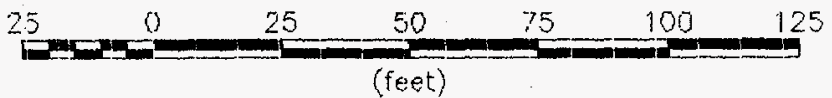

(feet)

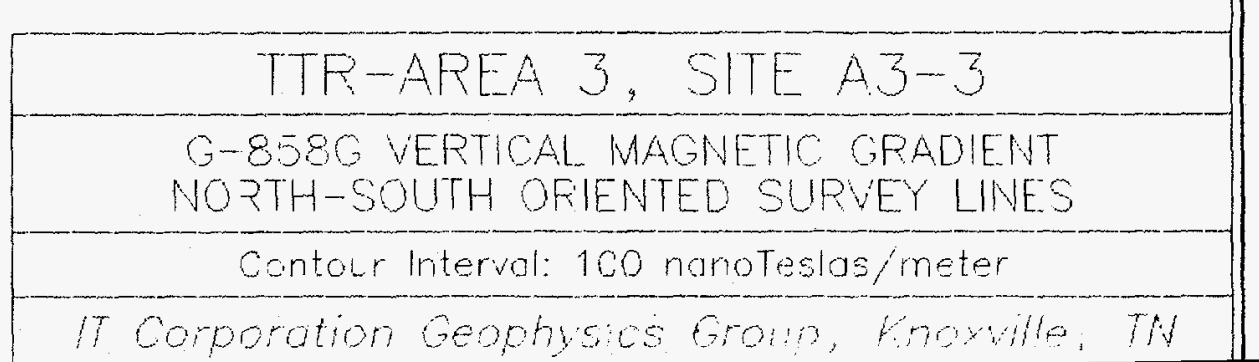




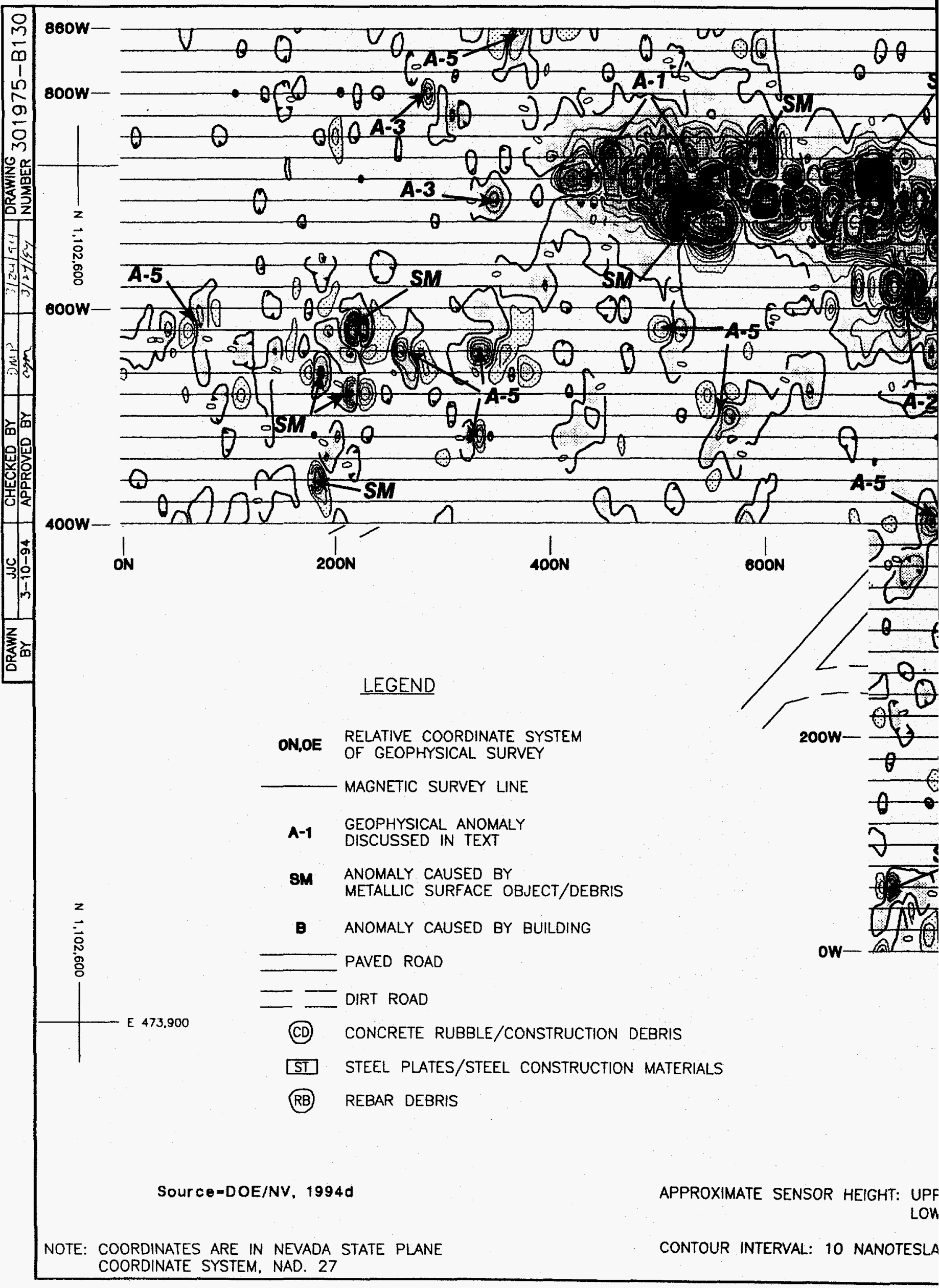




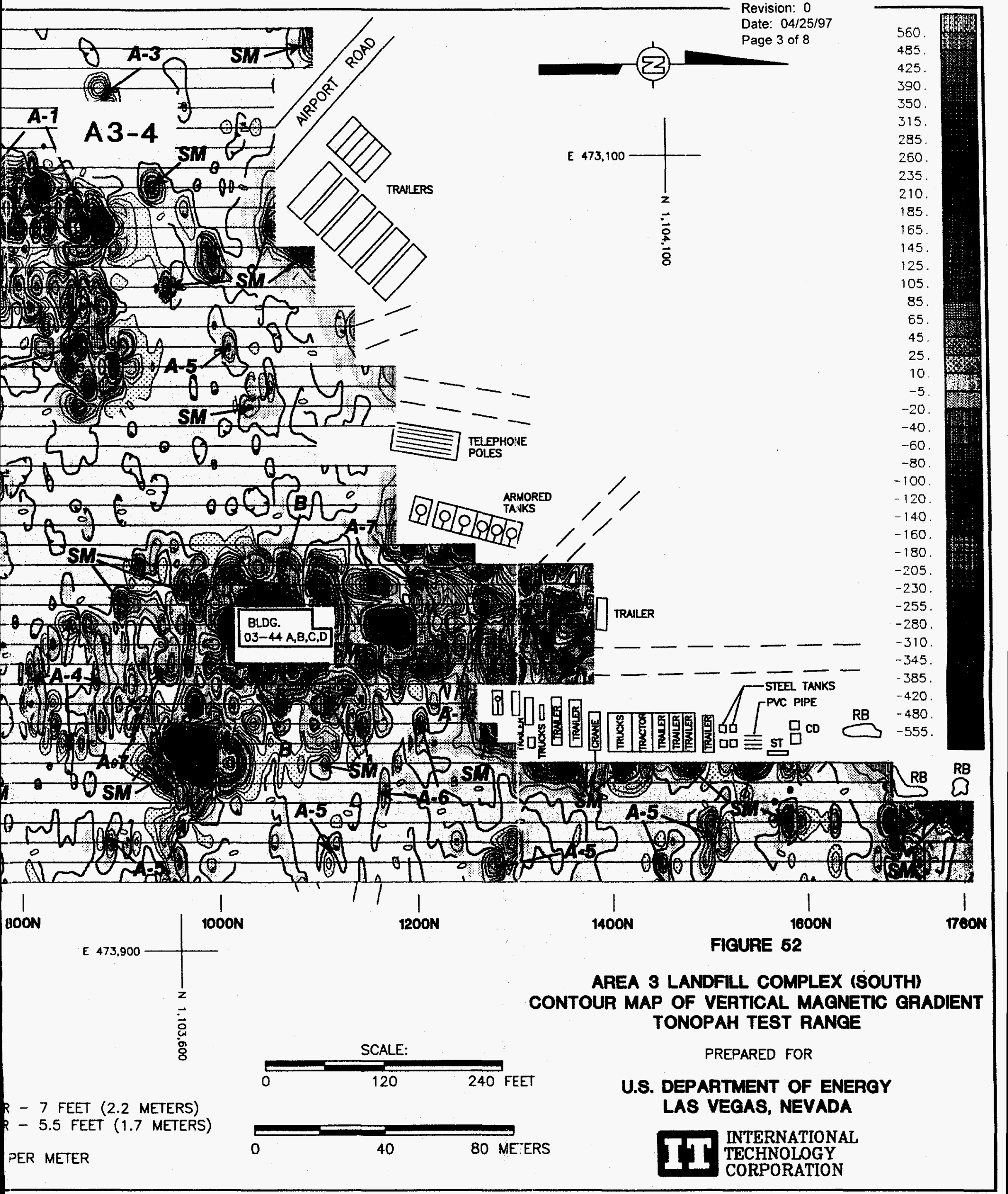




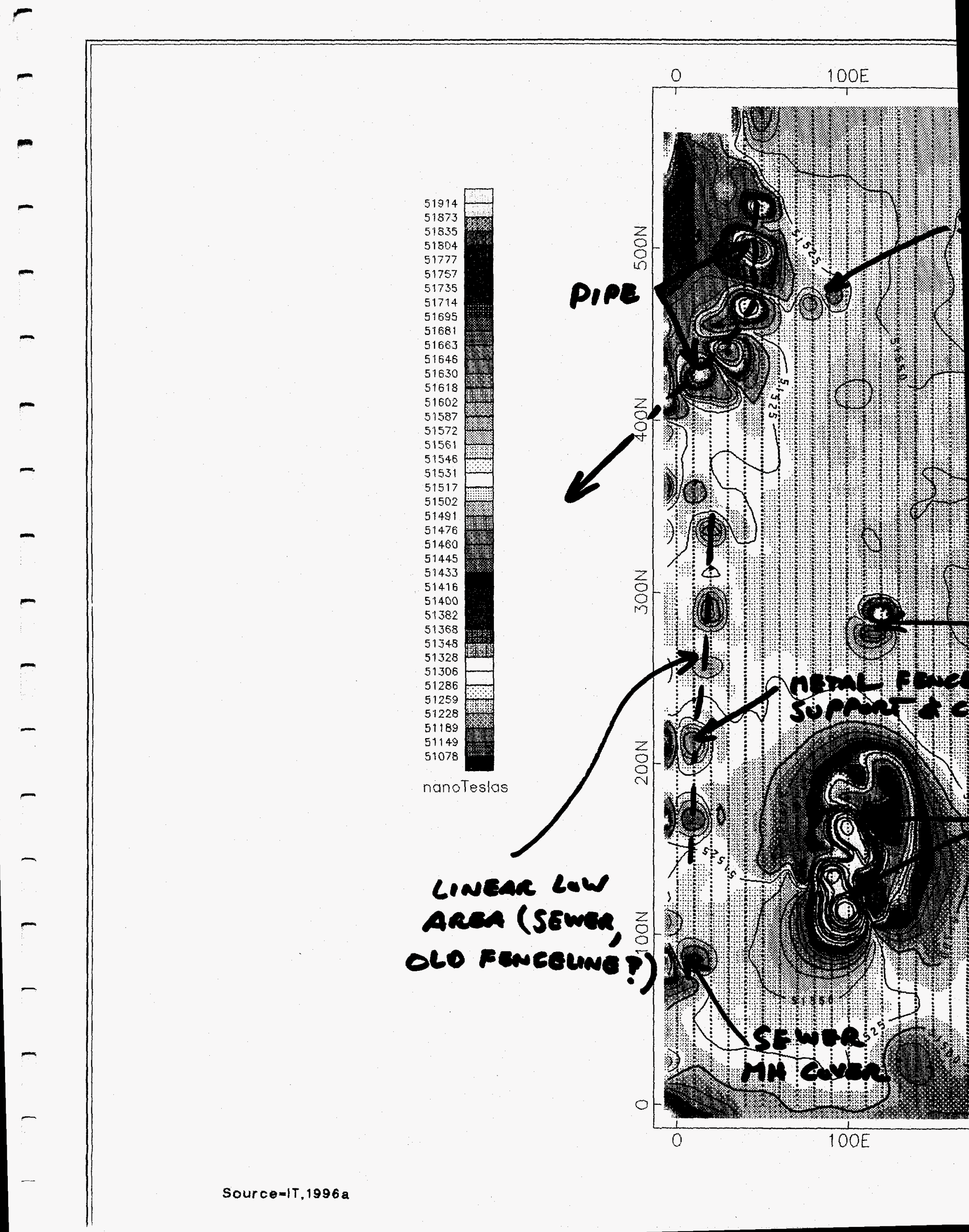



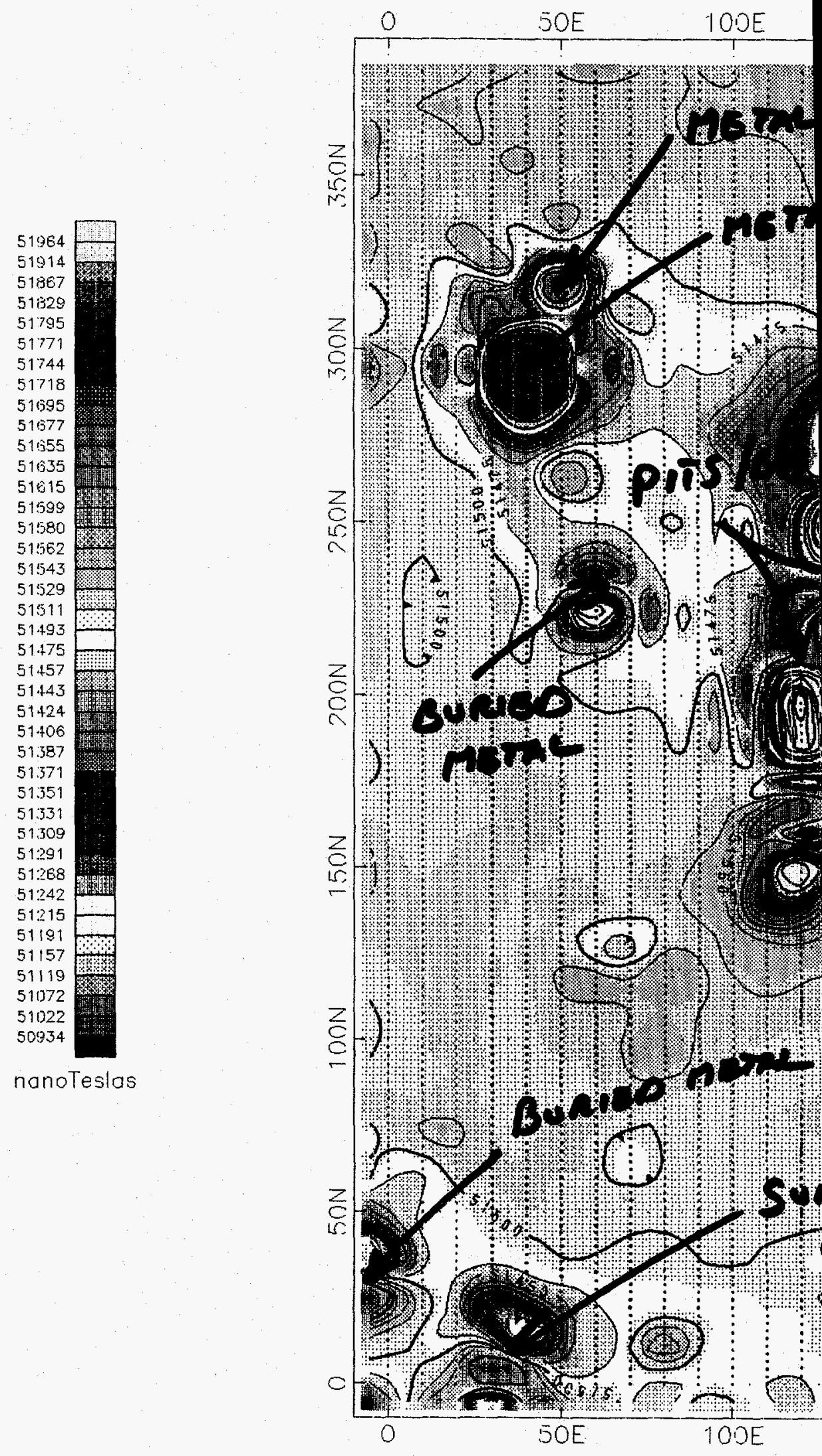


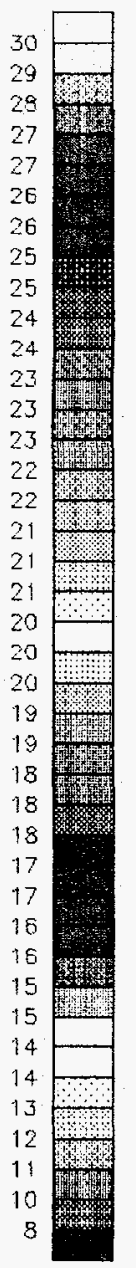

millisiemens/meter

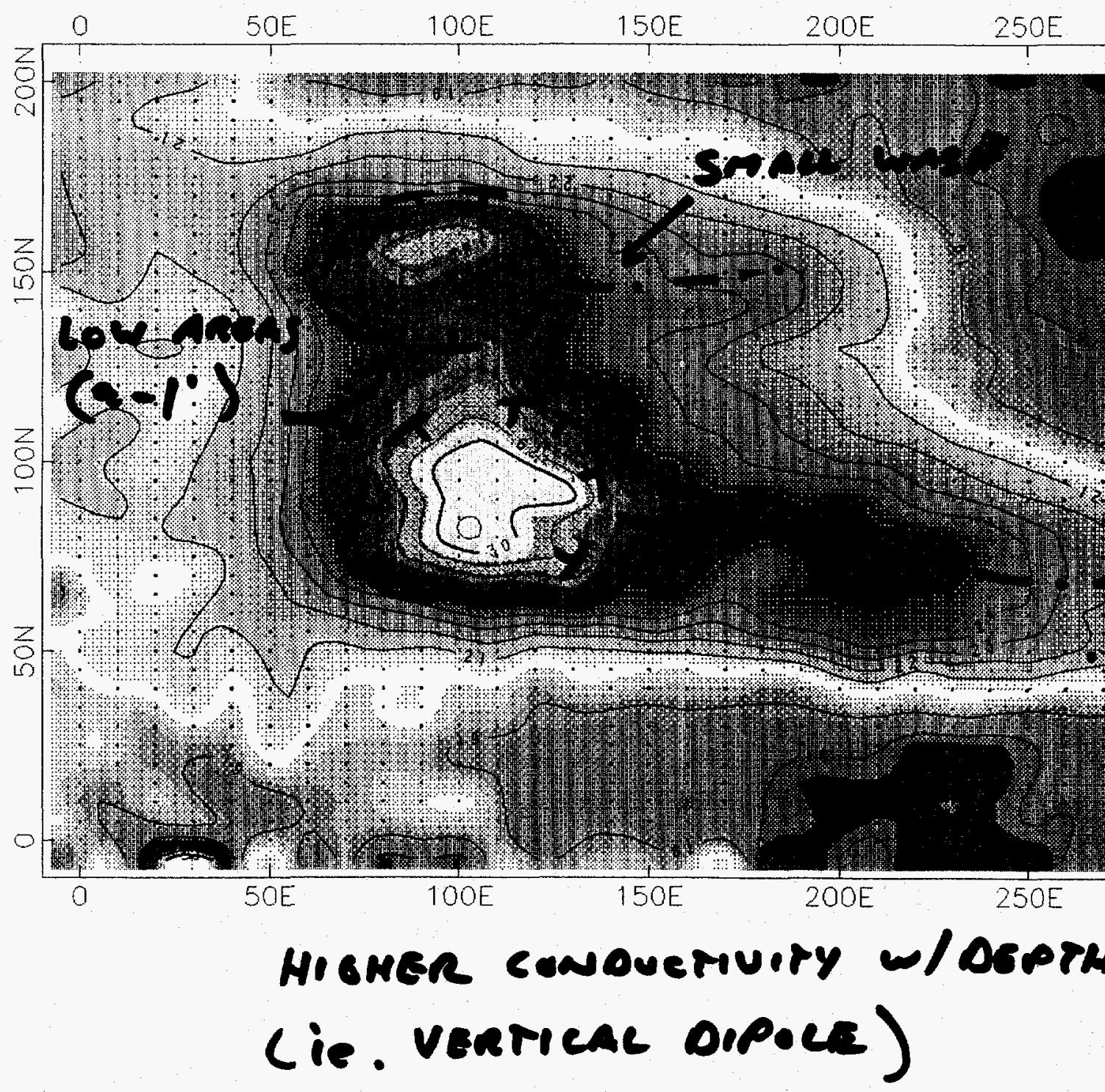


CAIP CAU No. 424

Section: Appendix C

Revision: 0

Date: $04 / 25 / 97$

Page 6 of 8
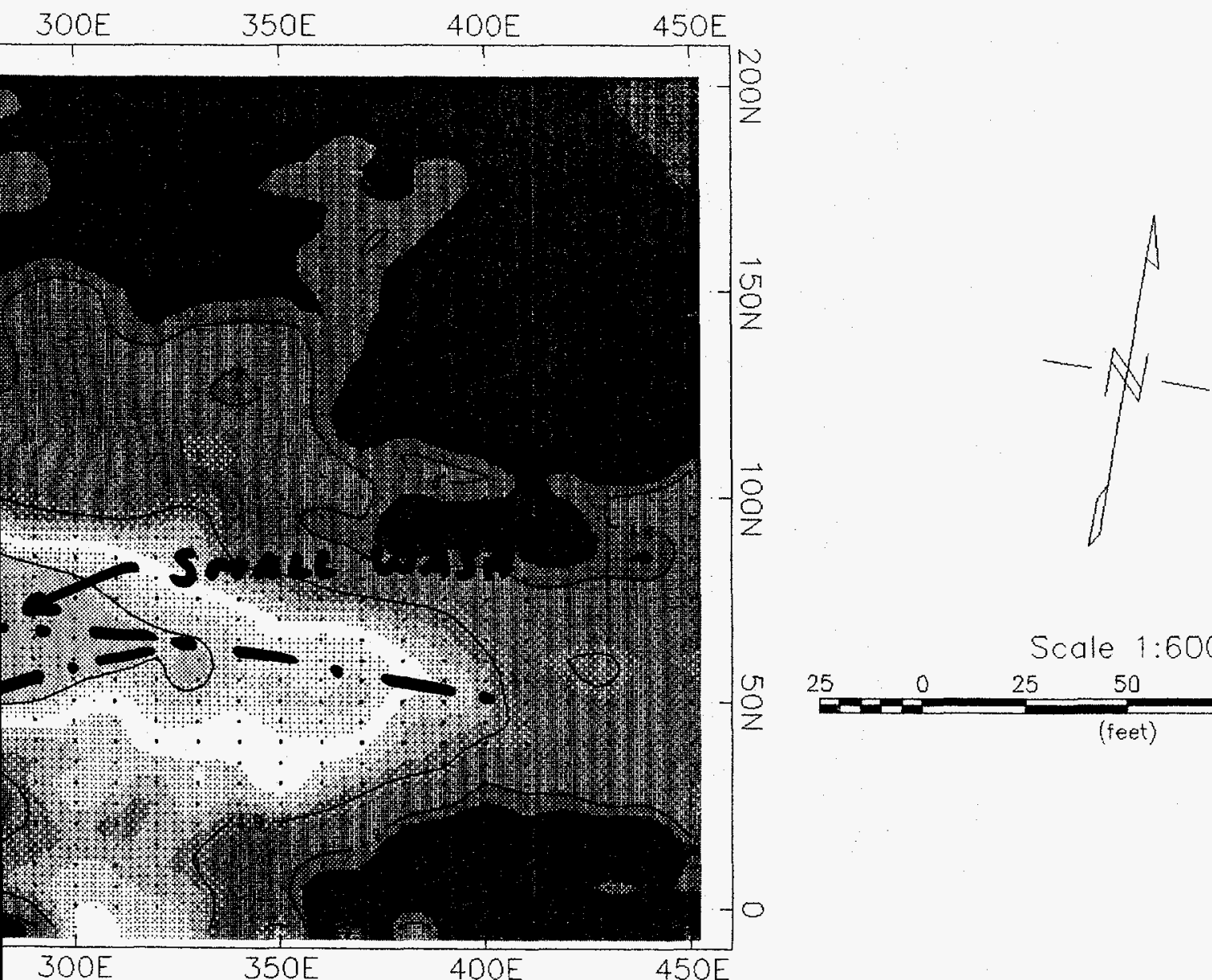

Scale 1:600

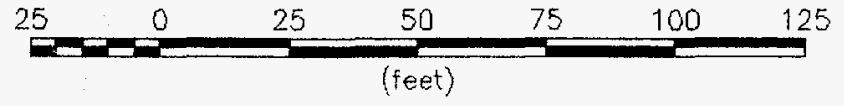

\section{TTR-AREA 3, SITE A3-7}

\section{EM-31 CONDUCTIVITY}

VERTICAL DIPOLE (3 FT ABOVE GROUND SURFACE) NORTH-SOUTH ORIENTED SURVEY LINES

Contour Interval: 1 millisiemen/meter

IT Corporotion Geophysics Group. Knoxwile. TN 


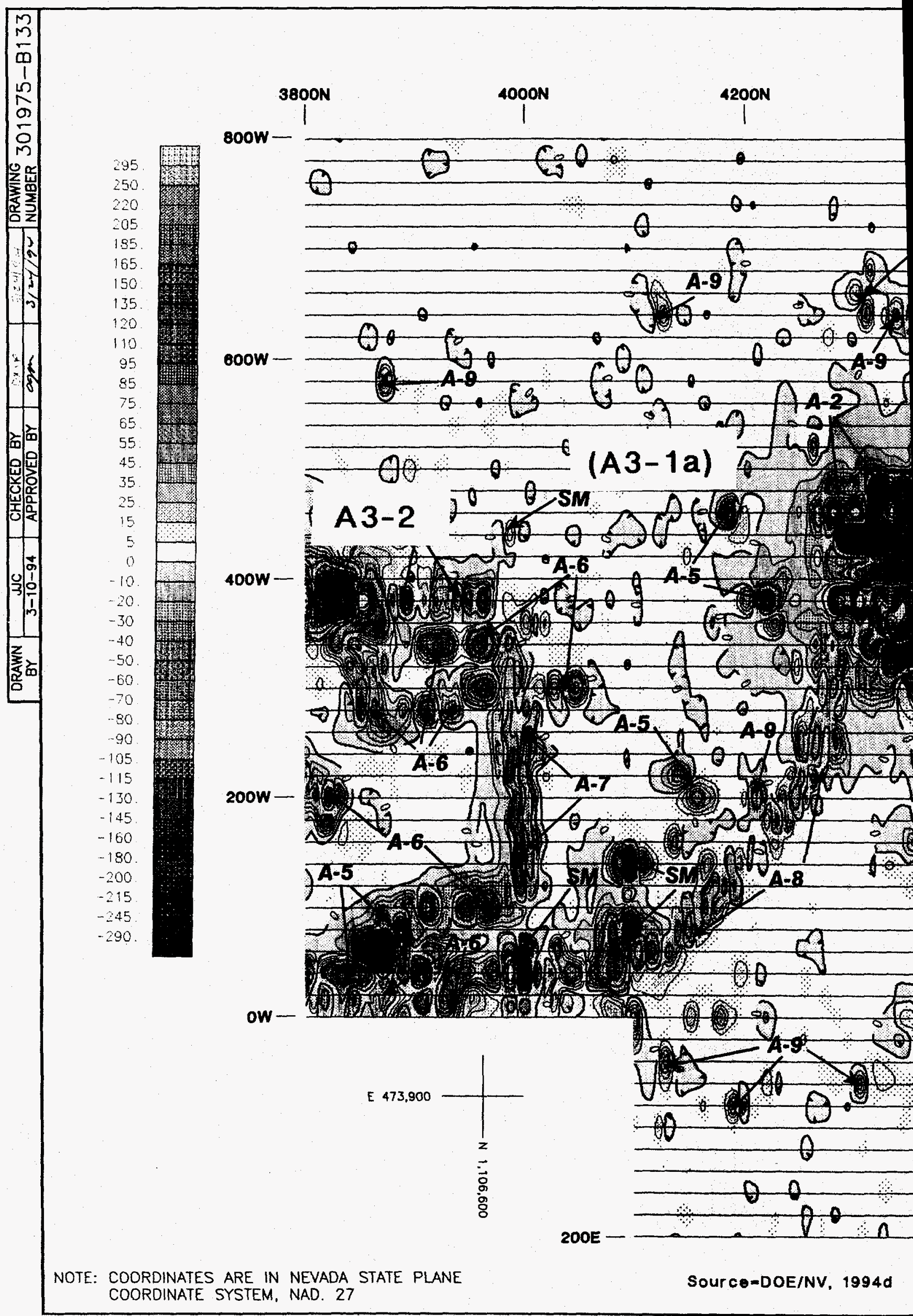




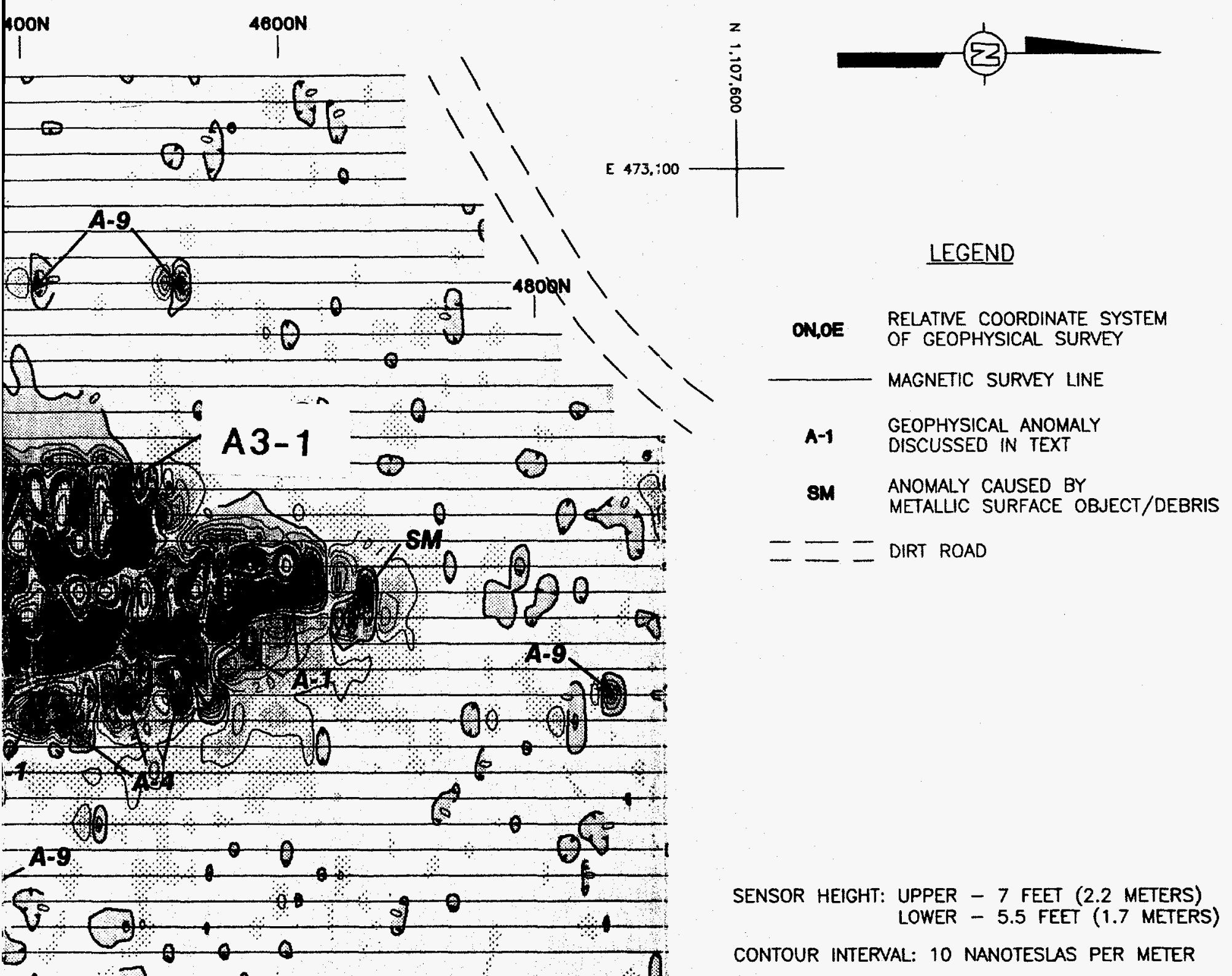

SCALE:

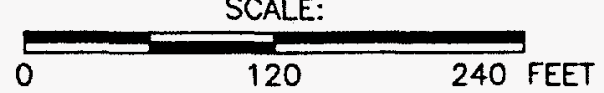

0

40

80 METERS
FIQURE 68

AREA 3 LANDFILL COMPLEX (NORTH) CONTOUR MAP OF VERTICAL MAGNETIC GRADIENT E 473,900 TONOPAH TEST RANGE

PREPARED FOR

U.S. DEPARTMENT OF ENERQY LAS VEGAS, NEVADA

IT INTERNATIONAL TECHNOLOGY CORPORATION 
CAIP CAU No. 424

Section: Plate 1

Revision: 0

Date: $04 / 25 / 97$

Page 1 of 2

\section{Plate 1}

\section{Area 3 Landfill Complex and \\ Planned Borehole Locations, Tonopah Test Range}




\section{NOTICE}

Page(s) size did not permit electronic reproduction. Information may be purchased by the general public from the National Technical Information Service, U.S. Department of Commerce, Springfield, VA 22161 (Area Code 703-487-4650). DOE and DOE contractors may purchase information by contacting DOE's Office of Scientific and Technical Information, P.O. Box 62, Oak Ridge, TN 37831, Attn: Information Services (Area Code 423-576-8401). 


\section{Distribution List}

* Provide copy on initial distribution of Rev. 0 ; remainder of list gets Rev. 0 if approved without changes, and entire list receives distribution of Rev. 1, if issued:

\section{Controlled copies}

Paul Liebendorfer

Bureau of Federal Facilities

Division of Environmental Protection

333 W. Nye Lane, Room 138

Carson City, NV 89706-0851

Chuck Bulik

Bureau of Federal Facilities

Division of Environmental Protection

555 E. Washington, Suite 4300

Las Vegas, NV 89101

Sabrina Bonnell

Environmental Restoration Division

DOE/Nevada Operations Office

P.O. Box 98518, M/S 505

Las Vegas, NV 89193-8518
2*

$1 *$

$1^{*}$

\section{$\underline{\text { Uncontrolled copies }}$}

DOE Public Reading Room

1

P.O. Box 98521, M/S NLV040

Las Vegas, NV 89193-8521

Rosa Silver

2

IT Corporation

4330 S. Valley View, Suite 114

Las Vegas, NV 89103

U.S. Department of Energy

Office of Scientific and Technical Information

175 Oak Ridge Turnpike

P.O. Box 62

Oak Ridge, TN 37831 
Uncontrolled copies

DOE/Nevada Operations Office

Technical Information Resource Center

P.O. Box $98518, \mathrm{M} / \mathrm{S} 505$

Las Vegas, NV 89193-8518

Janet Appenzeller-Wing

Environmental Restoration Division

DOE/Nevada Operations Office

P.O. Box 98518, M/S 505

Las Vegas, NV 89193-8518

Kevin Cabble

Environmental Restoration Division

DOE/Nevada Operations Office

P.O. Box 98518, M/S 505

Las Vegas, NV 89193-8518

Dave Madsen

Bechtel Nevada

P.O. Box 98521, M/S NTS306

Las Vegas, NV 89193-8521

Steve Nacht

Bechtel Nevada

P.O. Box 98521, M/S NTS306

Las Vegas, NV 89193-8521

Vern Gabbard

Sandia National Laboratories

P.O. Box 871

Tonopah, NV 89049

Ken Beach.

IT Corporation, M/S 439

4330 S. Valley View, Suite 114

Las Vegas, NV 89103 


\section{Uncontrolled copies}

Randy Dubiskas

IT Corporation, M/S 439

4330 S. Valley View, Suite 114

Las Vegas, NV 89103

Don Cox

IT Corporation, M/S 439

4330 S. Valley View, Suite 114

Las Vegas, NV 89103

Cheryl Rodriguez

IT Corporation, M/S 439

4330 S. Valley View, Suite 114

Las Vegas, NV 89103

Mike Doe

IT Corporation, M/S 439

$4330 \mathrm{~S}$. Valley View, Suite 114

Las Vegas, NV 89103

Robert Bull

IT Corporation, M/S 439

4330. S. Valley View, Suite 114

Las Vegas, NV 89103

IT Corporation Central Files

IT Corporation, M/S 439

4330 S. Valley View, Suite 114

Las Vegas, NV 89103

DOE Public Reading Room

P.O. Box 98521, M/S NLV040

Las Vegas, NV 89193-8521

$1^{*}$ 